\title{
CONTRIBUIÇ̃̃O PARA O ESTUDO DO PROBLEMA DA SIFILIS NA CAPITAL DE SÃO PAULO
}

JOSE MARTINS DE BARROS

I N T R O D U C C $\tilde{A}$ O

O estudo do problema da sífilis no Brasil, sob o ponto de vista sanitário, apesar de sua relevante importância, ainda está para ser realizado.

Os resultados apresentados pela grande maioria dos trabalhos que têm sido publicados sôbre a frequência da sífilis em nossa população devem ser rectbidos com reservas, pois costumam ser elaborados sem levar em conta alguns princípios básicos de estatística. As falhas principais dizem respeito, principalmente, à não representatividade das amostras, à falta de uniformidade da apresentação de dados, às falhas de técnicas de laboratório etc.

A inexistência de um órgão que controle com eficiência as doenças venéreas, a falta de coordenação entre os vários serviços que atendem o portador de sífilis, a ausência de notificação dessas doenças por parte da classe médica, e outras falhas, constituem um grande obstáculo para uma apreciação do problema.

Para que se possa elaborar um plano de contrôle da sífilis em saúde pública torna-se imprescindível, no entanto, o conhecimento, pelo menos aproximado, dos seus coeficientes de incidência e prevalência. Ora, tais dados, são, praticamente, desconhecidos entre nós. Existe apenas a tradição de que somos um povo de sifilíticos, e as estimativas a respeito da provável taxa de prevalência na população variam consideràvelmente, chegando alguns a imaginar cifras alarmantes.

Interessados, como sanitaristas, na elaboração de um programa de contrôle das doenças venéreas para a capital de São Paulo, notamos que a existência de dados mais precisos sôbre a situação dessas doenças, da sífilis, principalmente, era indispensável e de caráter urgente, para a orientação de futuras medidas técnico-administrativas. Daí a razão do presente trabalho, com o qual desejamos trazer alguma contribuição para o preenchimento da lacuna apontada.

Procuramos estudar grupos da população nos quais, por suas características, e segundo a experiência de outros autores, a sífilis costuma incidir em taxas muito elevadas, em contraste com outros em que as referidas taxas são bai-

Tese apresentada à Comissão Julgadora do Concurso para a Docência Livre da Cadeira de Venereologia e Leprologia da Faculdade de Higiene e Saúde Pública da Universidade de São Paulo. 
xas. Estudamos no primeiro grupo as prostitutas da zona do meretrício, presidiários e soldados; no segundo grupo incluímos os estudantes da Universidade. Um terceiro grupo observado, para o qual esperávamos encontrar uma taxa de valor médio quanto à prevalência da sífilis foi representado pela população operária.

Comprovando a importância que um estudo desta natureza representa para a saúde pública, transcrevemos aqui as palavras de abertura do relatório do Comitê de Peritos em Doenças Venéreas da Organização Mundial de Saúde:

"A solução desejável para o desenvolvimento de programas nacionais e internacionais de combate às doenças venéreas residiria na determinação acurada da magnitude do problema, realizada através de pesquisas sorológicas e de outros meios, para a colheita de informações sôbre a incidência dessas doenças.

Os países deveriam ser encorajados a coletar, pelo menos, os dados básicos".

(Do "Relatório do Comitê de Peritos em Doenças Venéreas” à Comissão Interina da Organização Mundial de Saúde, abril de 1948). 


\section{AS DOENÇAS VENEREAS}

Compreendem as doenças venéreas um certo número de infecções, cujo contágio se processa, comumente, através das relações sexuais, e cuja disseminação se deve, principalmente, à promiscuidade sexual.

São elas: a Sífilis, a Gonorréia, o Cancro mole, o Linfogranuloma inguinal e o Granuloma venéreo.

Outras moléstias existem que podem se enquadrar dentro das características epidemiológicas que enunciamos para as doenças venéreas, tais como o papiloma venéreo, certas balanopostites e uretrites não gonocócicas, pediculose do púbis, a própria escabiose etc., e são consideradas por muitos autores como sendo doenças para-venéreas.

A designação "venérea" não traduz senão o conceito em que tais doenças eram tidas no passado, quando delas se ocupavam mais os moralistas do que os próprios médicos.

Nos dias que correm, quando o problema das doenças infecciosas e contagiantes é discutido à luz da Epidemiologia, essa alusão maliciosa aos prazeres de Vênus para um grupo de moléstias é, não só inútil, mas também prejudicial.

Muitos estudiosos reconhecem nessa denominação obsoleta uma barreira aos objetivos do sanitarista que tem que lidar com tais doenças como problema de Saúde Pública.

A fim de evitar a associação que a expressão "venérea" provoca, muito naturalmente, com desregramentos sexuais, depravação etc., propõem alguns autores que se chame a êsse grupo, de "doenças sociais". Essa, no entanto, é também uma expressão pouco própria, pois, além de manter a estigmatização moral que se procura evitar, elas não são mais "sociais" do que as doenças que se transmitem pela via respiratória, por exemplo.

Nelson " sugeriu, há alguns anos atrás, o têrmo "Doenças infecciosas genitais", o qual nos parece bastante feliz. Tal denominação, entretanto, não conseguiu vencer a inércia criada pelo uso rotineiro da palavra "venérea" e, mesmo nos Estados Unidos, poucos especialistas aderiram à modificação proposta por aquêle autor.

\section{A importância da sifilis entre as doenças venéreas}

E' costume entre os sanitaristas, ao se referir a "doenças venéreas", ter em mente, de preferência, a infecção sifilítica.

Na verdade, o contrôle da gonorréia ainda é função da Saúde Pública, mas a simplicidade e rapidez da terapêutica moderna dessa moléstia, e mais a frequência elevada com que os pacientes procuram tratamento imediato, fizeram com que ela deixasse de constituir o problema sanitário alarmante que constituia há cêrca de uma década atrás. 
As outras doenças venéreas não são muito espalhadas, sendo que algumas delas só existem em certas regiōes do globo.

A sífilis, no entanto, devido à gravidade de suas complicaçōes, à sua maior facilidade de contágio e meios de transmissāo, à sua elevada frequência, e à facilidade com que pode passar despercebida até mesmo ao próprio paciente, deve ser considerada a doença mais importante do grupo.

Considerando-se que a existência das doenças venéreas depende, em última análise, do grau de promiscuidade sexual da população, é de se supor que, nas regiōes onde a sífilis for encontrada em elevada percentagem, o mesmo deve acontecer em relação às outras infecções venéreas. $E$, em virtude de ser a sífilis, pràticamente, a única capaz de ser reconhecida através dos exames de rotina e inquéritos em massa, constitui, portanto, o padráo pelc qual se costuma medir a incidência das doenças venéreas em uma coletividade.

\section{Constitui a sifilis um problema de Saúde Pública?}

Os cálculos referentes à sífilis, no mundo, acusam de 20 a 100 milhộes de casos novos por ano. As estimativas quanto à gonorréia são, pelo menos, três vêzes mais elevadas.

$\mathrm{O}$ índice de mortalidade pela sífilis, calculado em alguns países, oscila entre 0,8 a 210 por 100.000 habitantes. A mortalidade mundial devida às manifestações tardias da sífilis é avaliada em um mínimo de 2 milhões de sêres, anualmente. A mortalidade infantil devida à sífilis congênita chega a atingir, nos países atrasados, a $10 \%$.

Bauer ${ }^{2}$ afirma que a sífilis é um problema magno de Saúde Pública. 0 custo em vida humana dessa moléstia pode ser avaliado pelos milhares de mortes notificadas anualmente, milhares de paralíticos ou internados em hospitais de doenças mentais, e pelos milhares de crianças nascidas com sífilis congênita.

Em 1945 a sífilis causou nos Estados Unidos maior número de mortes do que várias doenças reunidas, tais como a paralisia infantil, febre reumática, malária, meningite cérebrospinal, febre tifóide e paratifóide, coqueluche, escarlatina, pelagra, alcoolismo e disenteria. 0 número de mortes devido à sífilis foi de 14.000 .

As perdas materiais devidas à sífilis podem ser avaliadas pelos seguintes dados, referentes aos Estados Unidos:

a) 11 milhōes de dólares anuais para manter sifilíticos em hospitais de doenças mentais.

b) De 4 a 6 milhôes de dólares anuais para a manutenção de cegos sifilíticos ${ }^{3}$.

Iskrant ${ }^{4}$ calculava, em 1940, que a perda de rendimentos devido à paralisia geral, nos Estados Unidos, orçava em 112 milhões de dólares. 
As doenças venéreas foram verificadas, com maior ou menor frequência, em todos os países do mundo. Não estão limitadas a nenhuma região do globo.

Reconhece-se que as informações estatísticas sôbre as doenças venéreas são falhas, e as que existem sôbre a incidência e prevalência (*) dessas doenças representam apenas uma taxa mínima de infecçōes.

\section{A I'REVALRNCIA DA SfFILIS NO MUNDO}

Dividem-se os autores em duas correntes quando se trata de averiguar de que região é a sífilis originária. Uns acham que ela já existia na Europa antes do descobrimento da América, e outros insistem em que foi levada para o velho continente pelos marinheiros de Colombo.

No entanto, quer se aceite ou não a origem americana da sífilis, o fato é que ela só teve grande disseminação na Europa no fim do século XV, durante a guerra de Nápoles, entre Fernando II e Carlos VIII de França, período que coincide exatamente com o regresso das expedições de Colombo. Deve-se notar ainda que, entre as fôrças espanholas que tomaram parte na luta, havia vários indivíduos que tinham integrado a expedição de Colombo.

0 regresso dos soldados mercenários das hostes de Carlos VIII às suas pátrias contribuiu para a difusão rápida por tôda a Europa da nova doença. E dessa época em diante começa a história da disseminação da sífilis, que não é senão a história do transporte da infecção de uma região para outra, pelos exploradores, colonizadores, guerreiros, mercadores, marinheiros e outros viajantes.

Não existe, em nossos dias, talvez, nenhuma parte habitada do globo que não tenha sido atingida pela infecção sifilítica. O problema da lues constitui um problema internacional de saúde pública.

A sifilis é uma das moléstias que mais dificuldade oferece à colheita de dados. Além de apresentar os inconvenientes comuns às demais moléstias infecciosas, é de caráter crônico, como a tuberculose, e oferece a particularidade de ser considerada doença vergonhosa, pelo que é frequentemente encoberta.

Smillie acha que a prevalência exata da sífilis não é conhecida, e que tem havido uma tendência a exagerar a importância e a sobrestimar a prevalência dessa doença, no entusiasmo do desenvolvimento dos métodos de contrôle.

Se, por exemplo, aplicarmos à populaçäo de 2 bilhões de sêres humanos do mundo a taxa anual de $100-200$ casos novos de sífilis para cada 10.000 in. divíduos, teremos de 2 a 4 milhōes de novos casos, anualmente.

(*) Prevaléncia da sífilis é o têrmo utilizado para indicar a proporção de indivíduos infectados, de uma maneira geral.

Incidência é o coeficiente de novas infecções em um determinado período de tempo (frequentemente I ano) 53 . 
Deve-se notar que o índice aplicado foi dos mínimos conhecidos. E', aproximadamente, a incidência de sífilis verificada nos países escandinavos.

Se aplicarmos um coeficiente de prevalência um pouco mais elevado, $3 \%$ por exemplo, aliás ainda não considerado como dos maiores, teremos um total de 60 milhões de sifilíticos no mundo.

Levando-se em conta as observações realizadas entre soldados do exército norte-americano sôbre a incidência da gonorréia, e aplicando à população do mundo a menor proporção encontrada entre sífilis e gonorréia, isto é, l para 3, teremos, no mínimo, a espantosa cifra de 180 milhões de sêres portadores de gonorréia.

A importância nacional e internacional das doenças venéreas pode ser entrevista através dêstes cálculos conservadores. Inúmeros autores são de opinião que a sifilis e gonorréia sejam muito mais frequentes do que os números computados nestes cálculos. Isso mostra que tais doenças representam um problema mundial de saúde, das maiores proporções.

Em 1948, o Comitê de Peritos em Doenças Venéreas ${ }^{5}$ apresentava um relatório à Comissão Interina da Organização Mundial de Saúde, com as seguintes palavras de Introdução:

"Reconhecendo o problema das Doenças Venéreas como de interêsse de saúde mundial e de relevante magnitude, o Comitê está inteiramente de acôrdo com o ponto de vista da Comissão Interina, que a malária, tuberculose e doenças venéreas merecem as mais altas prioridades entre as importantes atividades da Organização Mundial de Saúde, e que, sob vários aspectos, possui o problema das doenças venéreas um caráter internacional particular, ressaltado, principalmente, durante e após a última guerra".

Uma avaliação em escala global da magnitude do problema das doenças venéreas no mundo deve estar relacionada a relatórios minuciosos e acurados sôbre a morbidade e mortalidade nos vários paises, a pesquisas sôbre a sua prevalência na população, ou, de preferência, a ambos os métodos. A obtenção de tais dados, na época presente, é ainda muito falha. Por outro lado, a qualidade dos dados existentes sôbre a incidência, prevalência e mortalidade pelas infecções venéreas é a mais variada possível. Índices diferentes são aplicados em regiões diversas; taxas de prevalência, em regra, referem-se a grupos selecionados da população; as taxas de mortalidade são fragmentárias etc.

Dentre as inúmeras estimativas e trabalhos estatísticos referentes aos coeficientes de prevalência da sífilis nos vários países, destacamos as seguintes informações colhidas, principalmente, nos boletins informativos da Organização Mundial de Saúde, e no magnífico trabalho de Guthe e Hume sôbre os "Aspectos internacionais do problema das doenças venéreas" ". 


\section{Á F R I C A}

Africa Britânica do Sul

Foi calculado, em 1946, que $8,2 \%$ da população da Basutolândia era portadora de sífilis ${ }^{7}$.

\section{Etiópia}

Em 1937 a estimativa feita sôbre a prevalência da sífilis na população de Adis Ababa era de $55 \%$ para os adultos e $15 \%$ para as crianças.

Em 1944 as taxas de prevalência de sifilis para as diversas regióes do país variavam de 50,8 a $83,8 \%$.

Calculava-se, nesse mesmo ano, que $60 \%$ da população de Adis Ababa era portadora de gonorréia ${ }^{8}$.

\section{Á S I A}

Índia

Um inquérito feito entre os médicos da Índia Britânica, em 1939, o qual abrangia um total de 561 aldeias do país, mostrou uma incidência de sífilis igual a $1,56 \%$.

Japũo

Em 1947 a taxa de sifilis entre a população civil era de $0.22 \%$, segundo informações de autoridades médicas militares norte-americanas ${ }^{10}$.

China

Foi calculada em $10 \%$ a taxa de incidência da sifilis entre a população do sudeste da China, durante o período 1934-1936.

Em Kiangsu, nordeste da China, foi observada a taxa de $27 \%$ de sorologia positiva em pacientes de hospitais.

Exames sorológicos de rotina realizados em Soochow, Peiping e Shangai acusaram $17,3 \%$ de positividade ${ }^{11}$.

$$
\text { E U R O P A }
$$

Rússia

Em 1913 havia 1,8\% de casos conhecidos de sífilis entre a população, e em 1936 as estatísticas apresentavam a incidência de $0,18 \%{ }^{12}$.

\section{Alemanha}

Um inquérito de âmbito nacional realizado em 1940 mostrou que havia uma média de 4 casos de sífilis para cada 10.000 habitantes. 
A incidência da sífilis na zona americana da Alemanha, em 1947, era da ordem de 25 casos para cada 10.000 habitantes ${ }^{13}$.

\section{Polônia}

A incidência de reações sorológicas positivas na Clínica da Universidade de Varsóvia, em 1946, era de $42 \%{ }^{14}$.

Países escandinavos

Em 1946 haviam sido notificados uma média de 10 casos de sífilis adquirida, para cada 10.000 habitantes, na Dinamarca; 5.5 na Noruega e 2.2 na Suécia.

Deve-se esclarecer que essas taxas são, no mínimo, quatro vêzes mais elevadas do que aquelas que êsses países apresentavam antes da segunda guerra mundial ${ }^{15}$.

\section{Finlândia}

Durante o período da última guerra o país apresentava uma média de 6 casos de sifilis para cada 1.000 habitantes. Atualmente. calcula-se em 3 casos para cada 1.000 habitantes ${ }^{16}$.

\section{A M É R I C A}

Países pertencentes à região do Caribe ${ }^{1 T}$

Durante o período 1943-1945 a Comissão Anglo-Americana do Caribe rea. lizou um inquérito sorológico entre 38.895 habitantes dessa região da América, e o resultado foi o seguinte:

\begin{tabular}{|c|c|c|c|c|c|}
\hline Negros & & $26,4 \%$ & de & & tivos \\
\hline Brancos & $\cdots$ & $8,0 \%$ & $\cdot$ & & $"$ \\
\hline Índios & & $16.0 \%$ & $"$ & '" & 2" \\
\hline Chineses & $\cdots$ & $12,0 \%$ & $"$ & $"$ & $"$ \\
\hline Mestiços & & $24,0 \%$ & $"$ & , & $"$ \\
\hline
\end{tabular}

Venezuela

Um inquérito sorológico ${ }^{18}$, realizado em 1943, em Caracas, mostrou os seguintes resultados:

Positivos

Em 51.049 trabalhadores $\ldots \ldots \ldots \ldots \ldots \ldots \ldots \ldots . \ldots \ldots$

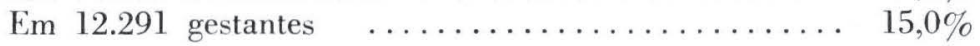

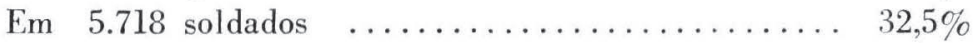

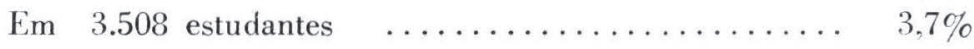




\section{Equador}

0 resultado de um inquérito sorológico realizado com a cooperação da Repartição Sanitária Panamericana, em Pôrto Viejo, capital da província de Manabi, em março de 1951, quando foram examinados todos os habitantes de idade superior a 15 anos, mostrou $17 \%$ de reaçóes positivas em 6.200 pessoas examinadas.

\section{Estados Unidos}

Smillie ${ }^{19}$ apresenta um quadro mostrando o resultado das reações de Wassermann realizadas em massa, em vários grupos sociais norte-americanos:

Segundo dados oficiais, fornecidos pela Comissão de Estudos de Sífilis, da Organização Mundial de Saúde ${ }^{20}$, a taxa por 1.000 habitantes, para todos os estágios da sífilis, na área continental dos Estados Unidos, declinou de cêrca de $3,5 \mathrm{em} 1941$ para $2,5 \mathrm{em} 1948$.

Esses dados são obtidos através da notificação obrigatória de todos os casos de sífilis entre a população civil do país. Embora de grande significação, êles não representam, no entanto, a extensão exata daquela moléstia entre a população.

Ainda existem, nos Estados Unidos, áreas onde os sistemas de pesquisa de casos e de notificação estão longe de ser o ideal, e onde as doenças venéreas não são descobertas ou não são notificadas.

Deve-se esclarecer que os coeficientes de prevalência da sífilis variam, nos Estados Unidos, de região para região, e segundo diversos fatôres, sendo o principal dêles a raça, como se pode verificar pelo resultado do exame do Selective Service entre 2 milhôes de homens examinados no período de 1940 a $1942^{21}$.

Os cinco Estados que mostraram a prevalência mais elevada foram:

\begin{tabular}{lccc}
\multicolumn{1}{c}{ Estadn } & Brancos & Pretos \\
Florida $\ldots \ldots \ldots$. & $5,3 \%$ & $40,6 \%$ \\
Texas $\ldots \ldots \ldots \ldots$ & $5,3 \%$ & $34,3 \%$ \\
Georgia $\ldots \ldots \ldots$ & $3,9 \%$ & $32,8 \%$ \\
Maryland $\ldots \ldots \ldots$ & $2,8 \%$ & $32,2 \%$ \\
Mississippi $\ldots \ldots$ & $3,5 \%$ & $32,1 \%$
\end{tabular}


Os cinco Estados com coeficientes de prevalência mais baixos foram:

\begin{tabular}{|c|c|c|c|}
\hline Estade & & Brancos & Pretos \\
\hline Wisconsin & $\ldots \ldots$ & $0,6 \%$ & $15,7 \%$ \\
\hline Minnesota & $\ldots \ldots$ & $0,8 \%$ & $14,2 \%$ \\
\hline Massachusset & $\ldots$ & $0,9 \%$ & $11,6 \%$ \\
\hline Connecticut & $\ldots \ldots$ & $0,9 \%$ & $20,7 c_{/ C}$ \\
\hline Rhode Island & $\ldots$ & $0,9 c^{\prime} ;$ & $9,2 \%$ \\
\hline
\end{tabular}

O coeficiente médio para o branco era, nessa época. igual a $2.3 \%$.

\section{SIFILIS NO BRASIL.}

Quase todos os estudiosos da história da sífilis no território brasileiro concordam que essa molestéia era desconhecida antes do seu descobrimento.

Segundo Eustáquio Duarte ${ }^{22}$, a sífilis saltou no Brasil com as primeiras levas de povoadores e aqui teve fácil expansão devido à miscibilidade característica do português. Teria sido ela a primeira doença estranha que dominou a patologia do Brasil colônia, e quando os negros aqui chegaram. já a encontraram na população.

Eduardo Rabelo ${ }^{23}$ também é de opinião que os indios não conheciam a sifilis quando os europeus aqui chegaram. Apoia-se nas descrições de Pero Vaz de Caminha, na experiência de Roquette Pinto, o qual não observou essa moléstia entre os índios; e na observação de Chagas. Termina o autor formulando duas hipóteses: ou a moléstia chegou ao país através das Antilhas ou veio com os exploradores europeus.

Suassuna ${ }^{24}$, baseado em informações do Serviço Nacional de Proteção aos Indios, afirma que não existe sífilis entre os nativos brasileiros que não entraram em contacto com os civilizados.

Martius (1844) descrevendo a natureza, doenças, medicina e remédios dos índios brasileiros. diz sôbre a sífilis: "E' crença geral dos índios que a doença foi introduzida pelos europeus. A sifilis é desconhecida nas tribos até hoje inacessíveis aos brasileiros; por isso não hesitamos em nos inclinar pela opinião que a considera como doença do Velho Mundo" 25.

Não existem provas consistentes de que os escravos tenham trazido a sífilis para o nosso país. Aliás, essa moléstia seria desconhecida no centro da África (Livingstone), e nas costas dêsse continente era conhecida como "doença francesa", ou "mal dos brancos" (Lanceraux).

Gilherto Freyre, em "Casa Grande \& Senzala", afirma que o negro se sifilizou no Brasil. 'Foram os senhores das casas-grandes que contaminaram de lues as negras das senzalas".

Talvez a existência da bouba na África se tenha prestado a algumas confusões entre os historiadores leigos, o mesmo acontecendo no Brasil.

Essa confusão, porém, não existe na obra de Guilherme Piso (1648), conforme se pode apreciar na sua descrição: "Êste mal é endêmico nesta região, 
sendo chamado Bubas por espanhóis e brasileiros. E assim como sara logo, só com remédios indígenas, assim contamina mais ràpidamente que o denominado Morbo Gallico, introduzido aqui, entre os habitantes desta terra" ${ }^{26}$.

Em 1872 a sífilis já era bastante frequente no Brasil, como se pode ter idéia através do "Mapa estatístico-patológico das praças entradas nos Hospitais e Enfermarias Militares do Município Neutro e Províncias do Império", relatório apresentado pelo Cirurgião-Mor do Exército, Dr. José Ribeiro de Souza Fontes ${ }^{2 \tau}$, segundo o qual "as moléstias que predominaram foram: 1") a sífilis, representada por 2.328 doentes; $2^{\circ}$ ) as do aparelho da respiração, com 1.779; $\left.3^{\circ}\right)$ as do aparelho da digestão, com 1.736" etc.

Infelizmente. não se conhece o efetivo da tropa nessa ocasião. de modo que não se pode calcular a frequência da moléstia apenas com êsses dados. Aliás, são quase nulos os dados merecedores de crédito sôbre a incidência ou prevalência da sífilis no Brasil, em épocas passadas.

Oscar Clark afirmava, no comêço do século, que “uma enfermaria de clínica médica. no Brasil, era, pràticamente, um serviço de sífilis visceral", e repetia, em 1911: "A frequência excessiva da lues venérea no Brasil é do domínio histórico e até viajantes estrangeiros, que percorreram o nosso país, levam a impressão de que quase todo nacional seja sifilítico" 2 .

Não é de admirar, portanto, que se tenha generalizado entre o vulgo o conceito de que nós somos um povo de sifilíticos, ou de que tôda a gente tem. " pelo menos um pouquinho" de sífilis.

Ainda nos dias que correm, os dados estatísticos sôbre a sífilis no território nacional são falhos. Os coeficientes de incidência ou prevalência dessa moléstia, trazidos à luz da literatura médica ou dos relatórios oficiais, dizem respeito via de regra. a amostras selecionadas. referentes a pacientes de hospitais e ambulatórios, sem grande valor, portanto.

Em virtude da ausência de dados, nós temos que nos contentar com conjecturas sôbre a frequência da sífilis em nosso país, em épocas passadas.

Os autores antigos insistem na frequência elevada dessa moléstia entre a nossa população e os velhos clínicos e sifilígrafos concordam com êles. Impõe-se, portanto, a seguinte indagação: Seria, de fato, a sífilis em tempos idos, muito mais frequente do que é hoje, tendo havido, posteriormente, certo declínio. ou seriam apenas falsas estimativas de amostras selecionadas; ou de interpretações de sinais de outras doenças que. na época. eram atribuidas à sífilis?

A resposta não é fácil porque. como já dissemos, não possuimos dados seguros para uma comparação.

Talvez a informação mais importante publicada até agora sôbre a situação da sífilis no Brasil tenha sido o inquérito sorológico realizado entre convocados e praças que deviam integrar a Fôrça Expedicionária, por ocasião da Segunda Guerra Mundial.

Entre junho de 1944 e abril de 1945 a Instituto de Biologia do Exército realizou 18.540 reações de Kahn nos candidatos à Fôrça Expedicionária. Essas reações, acrescidas de outras feitas por Almeida ${ }^{29}$ e Pedrosa ${ }^{30}$, perfazem um total de 36.694 .

A taxa de reações positivas encontrada foi de $14.04 \%$. 
Infelizmente, com exceção das informações referentes à graduação dos homens examinados, mais nenhuma outra informação foi fornecida. Seria de grande valia conhecer a constituição da amostra, principalmente no que se refere à idade, raça e procedência dos indivíduos.

\section{A SIFHLIS EM SÃO PALLO}

Os dados históricos relativos à existência da sífilis em São Paulo de Piratininga são escassos, mas se pode imaginar que ela aqui já havia feito o seu aparecimento com as primeiras levas de portuguêses, se dermos crédito aos his. toriadores que responsabilizam o europeu pela introdução dessa moléstia no Brasil.

As primeiras iniciativas, no entanto, tomadas nessa cidade em relação às doenças venéreas e à sua profilaxia, datam do início dêste século.

Em 1905, ano em que, na Europa, Schaudin e Hoffmann descobriram o Treponema pallidum, por iniciativa do Dr. Cláudio de Souza, foi criada uma Lig̣a anti-venérea. Além do combate às doenças venéreas, através de conferências e propaganda em jornais, tratamento gratuito das pessoas infectadas etc., a Liga se propunha a combater, também, o alcoolismo.

A sessão inaugural da Liga foi presidida pelo Presidente do Estado. Dr. Jorge Tibiriçá, e teve lugar em um prédio da rua Direita, sede da Policlínica de São Paulo. Logo no dia seguinte, no mesmo prédio, começou a funcionar o primeiro dispensário anti-venéreo da Liga, o qual recebeu, em homenagem ao seu fundador, o nome de "Dispensário Cláudio de Souza",

O dispensário foi mantido durante o seu primeiro ano de funcionamento à custa de contribuições mensais de um mil réis, contribuições essas provenientes de elementos de tôdas as classes sociais. No fim do primeiro ano, o Govêrno do Estado resolveu concçrer para a sua manutenção, mas, mesmo com essa subvenção e outra do Govêrno Federal, de quatro contos de réis, o Dispensário lutava com grande dificuldade de subsistência, razão pela qual foi trans. ferido para um prédio mais modesto, à rua José Bonifácio.

Não parou aí a odisséia do primeiro dispensário de tratamento de doenças venéreas instituido em. São Paulo. Foi transferido logo mais para a Averida São João, esquina da Praça Antônio Prado e, finalmente, para a rua de São Bento.

Em 1910, em virtude da falta de subvenções oficiais e da diminuição do número de sócios contribuintes, o Dr. Cláudio de Souza propôs a dissolução da Liga, pois ela dificilmente preenchia a finalidade a que se dedicara. Reunida a assembléia, esta, no entanto, foi contra o fechamento, e o Dispensário funcionou por mais dois anos.

Em dezembro de 1911, não podendo mais vencer as despesas, a Liga foi obrigada a cerrar as suas portas. $O$ saldo existente em valores foi distribuido a instituições de caridade e o material cirúrgico entregue à Policlínica de São Paulo.

O relatório da última diretoria da Liga, cujo presidente foi Monsenhor Camilo Passalacqua, expõe toda a história dessa nobre iniciativa, a primeira 
tentativa de profilaxia anti-venérea que se fez em São Paulo e, quiçá, no Brasil $^{31}$.

Em 1918, o Serviço Sanitário do Estado de São Paulo, na administração Arthur Neiva, criou 5 postos de profilaxia e tratamento gratuito da sífilis, atendendo a honrosa iniciativa do Centro Acadêmico Oswaldo Cruz e do Grêmio dos Internos dos Hospitais, associações de estudantes da Faculdade de Medicina e Cirurgia de São Paulo. Foi esta a primeira medida prática, de caráter ofi-

- cial, tomada no Brasil, em relação às doenças venéreas.

Em agosto de 1920, o diretor do Serviço Sanitário, Dr. Arruda Sampaio, resolveu fechar os postos de tratamento da Liga de Combate à Sífilis, com o intuito de reabrí-los mais tarde sob melhor organização. Não se conformaram os estudantes com essa atitude e reabriram-nos alguns dias mais tarde, custeando a manutenção da Liga com rendimentos de festas beneficentes e donativos angariados. Desde essa época, a Liga de Combate à Sífilis vem prestando uma valiosa contribuição na campanha contra as doenças venéreas em São Paulo, sempre com a cooperação dos estudantes da Faculdade de Medicina e sob a orientação clínica do Professor J. de Aguiar Pupo, da Clínica Dermatológica e Sifiligráfica da Universidade de São Paulo.

Em junho de 1920, o Govêrno Epitácio Pessoa, ao reorganizar os serviços de Higiene do país, com o decreto de regulamentação do Departamento Nacional de Saúde Pública, estabeleceu no Brasil a primeira legislação sôbre a profilaxia das doenças venéreas.

Deve-se esclarecer que os primeiros dispensários anti-venéreos da Capital Federal foram inaugurados em janeiro de 1921, sob a direção do eminente Professor Eduardo Rabelo, com a cooperação da Fundação Gaffrée-Guinle, fundada por iniciativa do Dr. Gilberto Moura Costa ${ }^{32}$.

Infelizmente, também não existem dados estatísticos seguros sôbre a frequência da sífilis em São Paulo, pois a sua situação não difere das de outras regiões do país. Não sendo moléstia de notificação obrigatória e nem existindo um órgão central coordenador da atividade dos inúmeros serviços espalhados pela cidade, que atendem o doente sifilítico, é impossível qualquer estudo sôbre o coeficiente de incidência desta moléstia.

Por outro lado, os índices de mortalidade pela sífilis têm pouca expressão. E' impossível precisar com exatidão a sífilis como causa de morte, pois ela permanece mascarada sob uma grande quantidade de sintomas e sinais, os quais variam desde a apoplexia e a miocardite crônica até a cirrose do fígado, à caquexia suprarrenal e alguns dos quadros obscuros da encefalite sifilítica.

No entanto, mesmo que o diagnóstico de sífilis pudesse ser estabelecido com precisão por todos os médicos, o que nem sempre se verifica, restaria o fator estigmatizante $\mathrm{da}$ moléstia, ainda considerada vergonhosa para muitas pessoas, e até mesmo para certos profissionais. E, como consequência disso, resultaria a troca do diagnóstico da "causa mortis" por uma doença menos "humilharite" para a família.

O Departamento de Saúde de Westchester, nos Estados Unidos, fez, em 1934, um estudo que revelou o pouco valor dos dados sôbre a mortalidade pela sífi- 
lis. Segundo êsse estudo, desde que os médicos têm a certeza de que os seus atestados de óbito são arquivados de maneira confidencial, suas informações sô. bre a sífilis como "causa mortis" atingem o dôbro das cifras primitivas":

A experiência que possuimos sôbre o número elevado de sinais e sintomas que clínicos menos informados costumam atribuir à sífilis, independentemente de um cuidadoso diagnóstico diferencial, nos faz pensar que, entre nós, uma outra causa de êrro pode ser importante: atribuir à sífilis uma causa de morte pela qual ela não é responsável.

Moore, manifestando-se sôbre êsse importante aspecto da questão, diz que, apesar de 400 anos de estudo, nós não conhecemos ainda a importância da sífilis como causa de morte; até que ponto ela se encontra disfarçada sob outros diagnósticos; ou até que ponto ela pode levar. indiretamente, à morte.

Brines "it estudou 618 autópsias do serviço de rotina, em Detroit, 1934. e encontrou sinais macroscópicos e microscópicos de lues em 8,7\% dos casos; Turnbull "... estudando mais de 7.000 necrópsias em Londres, entre 1908 e 1913. encontrou cêrca de $4 \%$ de lesões de sífilis adquirida; Pohlen : aviu 81.182 autópsias realizadas em Magdeburg entre 1928 e 1936 . e verificou $6.8 \%$ de si. nais morfológicos evidentes de sífilis.

Rosahn ${ }^{3 i}$ em seu magnífico trabalho sôbre o estudo das autópsias em sífilis faz uma crítica dos resultados encontrados pelos vários autores na literatura médica; resultados, no mais das vêzes discordantes, porque não foram conside. rados vários fatôres, principalmente a raça, o sexo, idade etc. Além disso. o critério de se considerar a lesão como de origem sifilítica ou não, variava segundo as escolas. Assim, para Warthin "38, "o diagnóstico da sífilis é, essencialmente, microscópico". Apenas em um número relativamente pequeno de casos seriam as lesões macroscópicas suficientemente típicas para que pudessem ser reconhecidas a ôlho nu.

O conceito de Warthin está em oposição àquele de Nickel ${ }^{39}$ e outros auto. res. Para êstes "apenas as lesões anatômicamente típicas de sífilis, isto é, a doença sifilitica vascular, a sifilis do sistema nervoso central, a sifilis dos ossos. a goma e a hepatite intersticial do recém-nascido" estariam incluidas entre os diagnósticos de certeza. Os sinais presuntivos não seriam considerados.

A conclusão de Rosahn é de que existe necessidade de se padronizar as alteraçôes morfológicas. macro e microscópicas, que seriam resultantes da infec. ção sifilítica.

$\mathrm{F}$ ' indisculível que os estudos estatísticos sôbre a morbidade e mortalidade pela sifilis dependem da padronização dos critérios de diagnóstico e da adoção de uma nomenclatura uniforme.

Freitas Filho e Campos Melo ${ }^{49}$. em um estudo sôbre a mortalidade pela sífilis nas diversas capitais brasileiras, apresentam os dados referentes ao período 1937-1939, para a capital paulista.

Ésses dados foram preparados e tabulados na Secção de Bioestatística do Departamento Nacional de Saúde e são apresentados no quadro da pág. seguinte. Os autores reconhecem, no entanto, que "o número de óbitos atestados como sífilis está muito aquém da realidade, em virtude, principalmente, de sua omissão proposital ou não, ou da deficiência diagnóstica. Sendo assim. é claro que são pouco expressivos e nada satisfatórios os resultados obtidos de seu estudo“. 
BARROS, J. M. de - CONTRIBUIÇÃO PARA O ESTUdO DO...

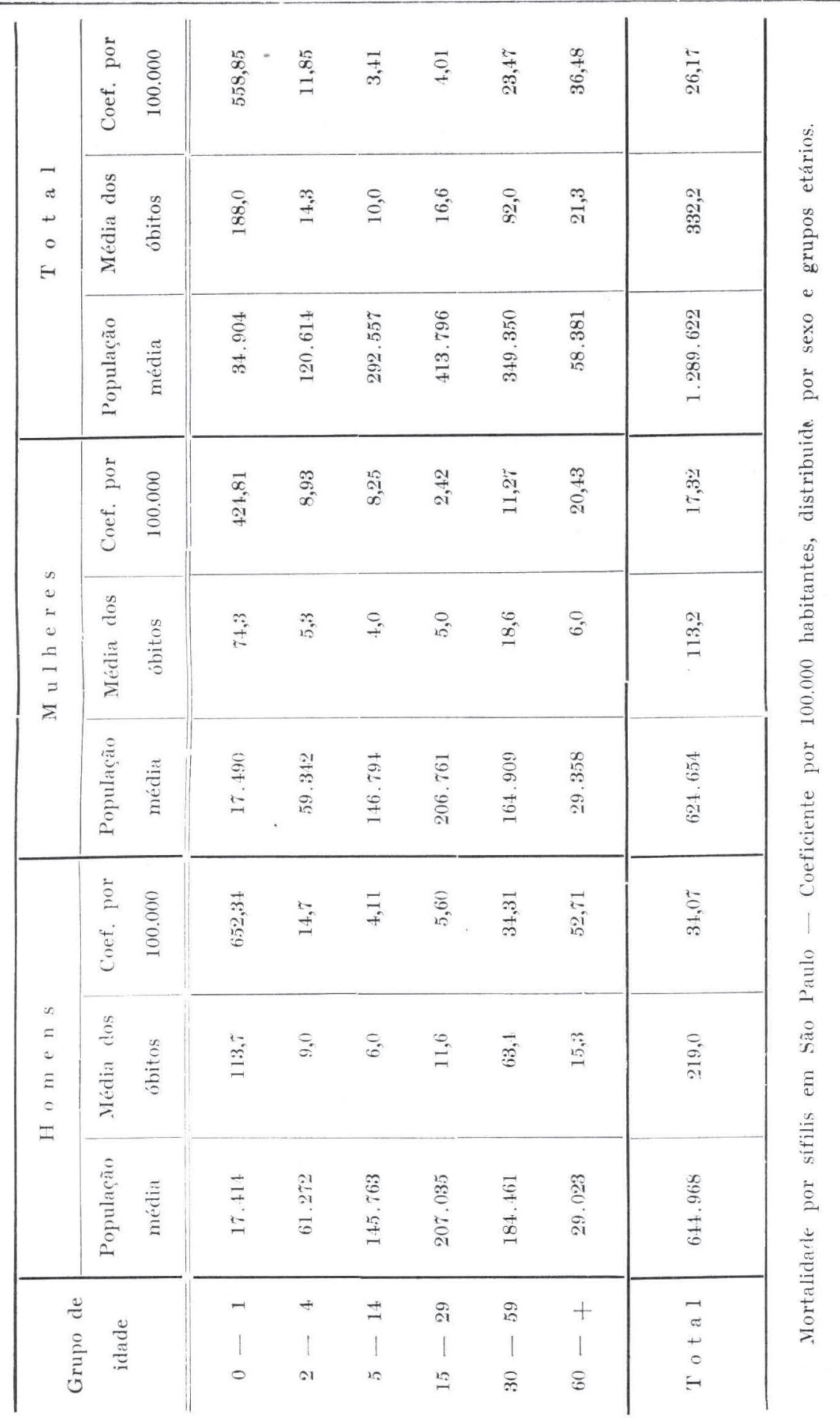


Em virtude do valor reduzido dos dados estatísticos referentes à mortalidade pela sífilis na capital de São Paulo, deixaremos de estudá-los convenientemente. Registramos apenas as informações mais recentes que conseguimos colher no Departamento Estadual de Estatística, e que dizem respeito aos anos de 1945-1946 e 1947, tais como nós as obtivemos:

1945

\begin{tabular}{|c|c|c|}
\hline $\begin{array}{c}\text { Brancos } \\
,\end{array}$ & $\begin{array}{l}\text { Mase. } \\
\text { Fem. }\end{array}$ & $\begin{array}{l}\ldots \ldots \ldots \ldots \ldots \ldots \ldots \ldots \\
\ldots \ldots \ldots \ldots \ldots \ldots \ldots \ldots\end{array}$ \\
\hline Pardos & Masc. & $\ldots \ldots \ldots \ldots \ldots \ldots$ \\
\hline " & Fen. & $\ldots \ldots \ldots \ldots \ldots \ldots$ \\
\hline P'retos & Masc. & $\ldots \ldots \ldots \ldots$ \\
\hline$"$ & Fem. & $\ldots \ldots$ \\
\hline Amarelos & Masc. & $\ldots \ldots \ldots \ldots \ldots \ldots \ldots$ \\
\hline " & Fen. & $\ldots \ldots \ldots \ldots \ldots \ldots$ \\
\hline Ignorados & Masc. & $\ldots \ldots \ldots \ldots \ldots \ldots$ \\
\hline ", & Fem. & $\ldots \ldots \ldots \ldots \ldots \ldots$ \\
\hline
\end{tabular}

Obitos gercis
8.930
7.163
802
855
938
1.046
140
104
1
2

19.981

óbitos gerais

8.440

6.574

824

818

864

878

151

Imarelos

Ignorados

"

Total

\section{Fem.}

Mase.

Fem.

.....................

Fem.

Mase.

Fem.

89

8

18.650

Obitos por sifilis
215
98
27
14
37
27
1
3
0
0

$1222(2,1 \%)$

obitos por sifilis 192

102

34

14

37

21

0

2

0

1

$10: 3 \quad(2,1 \%)$

1947

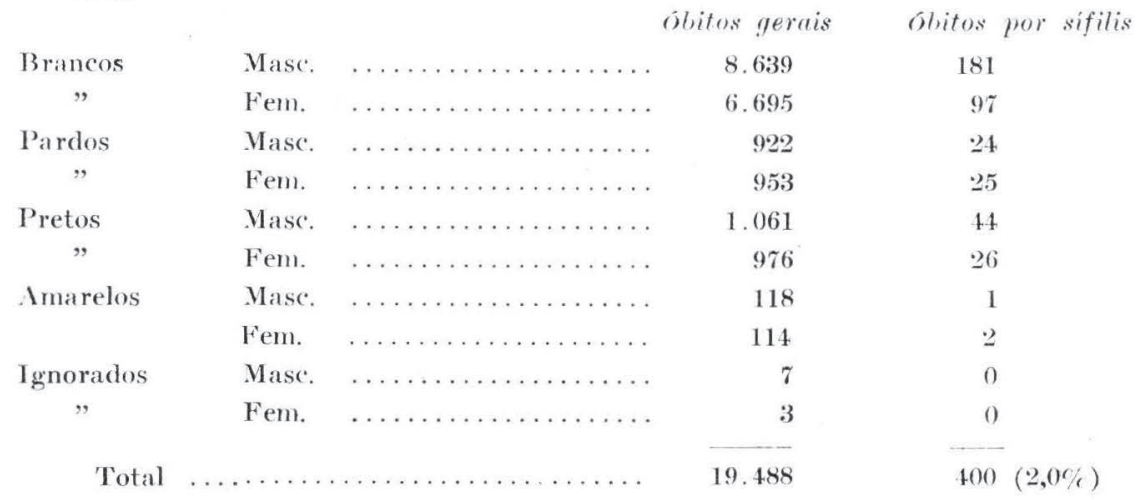


Em 1947 as causas de morte por sífilis foram:

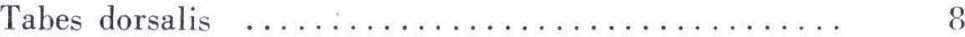

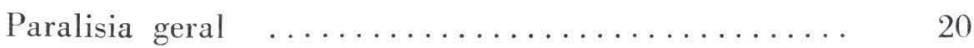

Aneurisma da aorta ................... 87

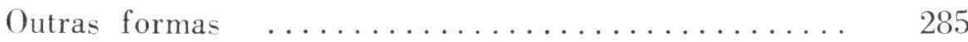

Um dos raros estudos feitos entre nós, baseados em achados de necrópsias, foi realizado por Mignone e Bicudo ${ }^{41}$ em 1948. Esses autores, pesquisando as causas da mortalidade neo-natal através de necrópsias de recém-nascidos da Clínica Obstétrica do Hospital das Clínicas e da Casa Maternal e da Infância. acharam que a sífilis foi a causa de morte em 9\% dos 200 casos examinados.

Em se tratando de recém-nascidos e de uma amostra proveniente de hospitais, a taxa encontrada não é, absolutamente, elevada.

Várias tentativas têm sido feitas para o estudo da prevalência da sífilis na capital de São Paulo, porém a maioria dos trabalhos é baseada em amostras selecionadas de hospitais, ambulatórios e dispensários, o que diminui muito o seu valor.

Em 1942, Rosa Borges ${ }^{42}$ publicou um estudo sôbre a infecção luética entre os bancários de São Paulo. Infelizmente o coeficiente de $31 \%$ de reações positivas encontradas em um grupo social diferenciado como os bancários, quando a taxa encontrada no Laboratório Central da Santa Casa era, na época, de cêrea de $20 \%$, faz pensar em falhas de técnica; possivelmente, de laboratório (antígenos muito sensíveis etc).

Entre os trabalhos realizados na capital paulista, a fim de apurar o coeficiente de prevalência para a cidade, podemos mencionar os de Waldomiro de Oliveira ${ }^{43}$ que, em 1936 , encontrou $17,9 \%$ de reaçóes positivas na Inspectoria de Profilaxia da Sífilis; Cerruti ${ }^{44}$, o qual encontrou uma taxa média de $20.0 \%$ de reações de Wassermann positivas, realizadas num período de 26 anos, no Laboratório Central da Santa Casa de Misericórdia de São Paulo: Bianco ${ }^{45}$, que encontrou $15,0 \%$ de reações positivas no Ambulatório de Pediatria do Hospital Humberto I; Porto e Brito ${ }^{46}$, em 1940 , encontrando $25.0 \%$ de positividade para sifilis em imigrantes nacionais; Paula Souza ${ }^{4 \tau}$, que encontrou $2.59 \%$ de reacões positivas entre estudantes das escolas superiores de São Paulo; Reina ${ }^{48}$ revelando dados sôbre a Clínica Obstétrica da Faculdade de Medicina de São Paulo, os quais responsabilizavam a sífilis em $21,1 \%$ das gestantes; Mendes de Castro ${ }^{49}$ encontrando $8,7 \%$ de casos de sífilis entre escolares da capital; Godoy ${ }^{50}$ verificando $14,4 \%$ de reações positivas entre 97 crianças, entre 3 e 30 meses de idade; e outros.

Ora, nós observamos uma grande discordância entre as taxas encontradas, e nem podia ser de outra maneira, visto que as amostras examinadas são provenientes de clínicas médicas, hospitais, ou dizem respeito a grupos selecionados da população, e, além disso, foram observadas em épocas diferentes. 
Mesmo entre grupos sociais semelhantes, os resultados são, às vêzes, dis. cordantes. E' o que se verifica a respeito das domésticas, por exemplo. Vieira Macedo ${ }^{51}$, em 1941, encontrou uma positividade igual a $35 \%$, e Matuk ${ }^{52}$, em 1943, examinando 600 domésticas, observou $11.5 \%$ de reações positivas.

O combate à sífilis e outras doenças venéreas é feito. na capital de São Paulo, através do Serviço de Sífilis da Capital, do Departamento de Saúde do Estado, e de várias instituições para-oficiais e particulares.

O Serviço de Sífilis da Capital presta assistência ao povo paulistano por intermédio de postos instalados nos Centros de Saúde. Estão êles distribuidos pelos seguintes bairros da cídade: Santa Cecília, Lapa, Santana, Braz. Belém. Vila Mariana, Santo Amaro, Pinheiros e Bom Retiro.

$O$ posto de sífilis que serve o bairro de Pinheiros e adjacências. funciona à noite, em cooperação com o Centro de Aprendizado da Faculdade de Higiene e Saúde Pública; e o posto do Bom Retiro, que até o primeiro semestre de 1951 estava subordinado à Secretaria da Segurança Pública, destina-se irincipalmente, a atender às mulheres da zona do meretrício, e a funcionar como preventório.

Dos mais antigos serviços de combate à sífilis é, como já mostramos no início dêste capítulo, a Liga de Combate à Sífilis, funcionando na Santa Casa de Misericórdia de São Paulo e mantendo um posto de tratamento noturno à rua General Jardim. Esse serviço, mantido pelos estudantes da Faculdade de Medicina da Universidade de São Paulo, é inteiramente gratuito.

Os acadêmicos da Escola Paulista de Medicina também mantêm um serviço semelhante, funcionando na Policlínica da rua do Carmo, mediante o pagamento de pequena taxa por parte do paciente.

0 diagnóstico e tratamento gratuito da sifilis pode ser feito, ainda. no Ambulatório da Clínica Dermatológica e Sifiligráfica do Hospital das Clínicas.

Gutros serviços assistenciais existem, restritos, porém, a certas áreas da cidade ou a grupos da população. O Serviço de Sífilis do Centro de Aprendizado da Faculdade de Higiene e Saúde Pública, por exemplo, limita as suas atividades aos habitantes do bairro de Pinheiros, embora atenda, também, em caráter de exceção, a todo o doente contagiante que o procura.

As gestantes sifilíticas, além dos postos já mencionados, são atendidas na Clínica Obstétrica do Hospital das Clínicas, Casa Maternal e da Infância, e nos postos da Cruzada Pró-Infância. O tratamento é inteiramente gratuito.

As crianças, além dos postos oficiais, recebem assistência através da Cruzada Pró-Infância. Clínica Infantil do Ipiranga e Departamento Estadual da Criança.

Os universitários recebem assistência gratuita do Serviço de Sífilis do Centro de Aprendizado da Faculdade de Higiene e Saúde Pública.

Existem, ainda, em São Paulo, instituições para-oficiais e particulares que tratam do associado, portador de sífilis, através de serviços de dermatologia. como por exemplo o Instituto de Aposentadoria e Pensões dos Comerciários, Instituto de Aposentadoria e Pensões dos Industriários etc. 
O Serviço Social da Indústria (SESI) mantém um Serviço de Sífilis, o qual procura descobrir e tratar a sífilis no meio operário. Apenas o medicamento (penicilina) é cobrado, a preço de custo. Todos os exames são gratuitos.

Os funcionários municipais recebem assistência através do serviço especializado do Ambulatório do Hospital Municipal.

Os militares são atendidos nos Ambulatórios ou Hospitais Militares, do Exército ou da Fôrça Pública.

Como se pode notar, não existe na capital de São Paulo falta de assisiência em relação aos meios de diagnóstico e de tratamento da sífilis. O que existe é uma dispersão de atividades nesse sentido, sem um contrôle geral.

Os diversos Serviços de tratamente da sífilis trabalham isoladamente, sem haver qualquer entendimento ou colaboração entre êles. Não há uniformidade de tratamento e nem de colheita de dados.

A consequência disso é a impossibilidade de se conseguir dados sôbre a incidência da sífilis e outras doenças venéreas, ou qualquer informação, mais ou menos precisa sôbre o assunto.

\section{() INQTERITO SOROLGGICO NO ESTUDO DA PREVAIANCIA DA SIFILIS}

Vão há, pràticamente, informações sôbre a incidência da sífilis em São Paulo. e muito poucas informações, dignas de crédito, sôhre a sua prevalência.

Os estudos sôbre a prevalência da sífilis baseiam-se, via de regra, no censo de um dia e nos inquéritos sorológicos; e êstes podem ser classificados, stimàriamente. em três grupos:

a) inquéritos resultantes de exames médicos em hospitais, ambulatórios, clínicas particulares etc.;

b) inquéritos realizados entre indivíduos selecionados sob o ponto de vista social, econômico ou profissional, como por exemplo os ferroviários, prisioneiros, estudantes etc.;

c) inquéritos realizados em grupos reconhecidos como amostra representativa da comunidade ${ }^{53}$.

- O censo de "um dia" procura fornecer informações relativas à prevalência e à incidência da sífilis. Em um determinado dia, em uma certa localidade ou região, todos os médicos e serviços especializados de doenças venéreas devem fornecer dados referentes ao número de pessoas sob tratamento ou contrôle de sífilis. Além disso, devem mencionar o número de pessoas que procuram diagnóstico ou tratamento pela primeira vez, em um determinado período de 30 dias ${ }^{54}$.

O censo de "um dia" é de difícil realização, mesmo em países com Serviços Antivenéreos organizados. Os inquéritos feitos entre grupos da população, considerados como amostras representativas da população, podiam ser realizados, principalmente, entre os convocados para o serviço militar, o que não é feito entre nós. 
Além das influências da raça, sexo, idade e fatôres sociais e econômicos, e dos possíveis erros de colheita de amostras, existem outras causas de êrro que não podem ser eliminadas dos inquéritos feitos em massa, por mais cuidado que se tome. Alguns indivíduos com sorologia duvidosa ou positiva podem ser classificados, devido a falsas reações, como portadores de sífilis; e outros, com sorologia negativa, classificados como não sifilíticos, embora portadores da mo. léstia.

O inquérito sorológico para o diagnóstico da sífilis, se não é uma das medidas mais práticas e econômicas do ponto de vista de Saúde Pública, quando se busca descobrir casos novos, é, no entanto, um dos métodos mais eficazes para se avaliar a prevalência da sífilis em uma população, quando não existem outros meios informativos, como por exemplo a notificação obrigatória, ou dados estatísticos seguros sôbre a morbidade e mortalidade.

Embora não se acredite que o resultado dos exames seja, necessàriamente, idêntico ao coeficiente de prevalência da sífilis, não se pode negar, entretanto, uma relação muito aproximada entre ambos.

Deve-se esclarecer que houve uma inversão quanto aos meios de diagnóstico da sífilis. Até certo tempo atrás o diagnóstico dessa moléstia era, principalmente, clínico, e as reações sorológicas tinham por finalidade confirmá-lo. A negatividade de uma reação não implicava no abandono do diagnóstico, e o tratamento era instituido, frequentemente, à revelia dos resultados do exame de sangue.

Autores chegaram a publicar trabalhos sôbre a prevalência da sífilis na população levando em consideração, quase que exclusivamente, o que êles consideravam sinais clínicos e distróficos, independentemente da positividade ou negatividade das reações, quando estas eram feitas. Assim, um autor chegou a encontrar $40 \%$ de portadores de sífilis congênita entre 2.000 escolares do Distrito Federal, baseado apenas nos "sinais distróficos" da moléstia ${ }^{5.5}$.

A simplificação das reações sorológicas, o aperfeiçoamento de suas técnicas, a padronização dos antígenos, a descoberta de antígenos mais sensiveis e específicos e, principalmente, um critério mais seguro para se classificar os sinais da sifilis, criaram uma situação inversa. E' muito mais frequente, hoje em dia, descobrir-se a moléstia através de um exame de sangue em indivíduos que não apresentam sinais ou queixa que pudessem levá-los a procurar o médico ${ }^{56}$.

Se as reações sorológicas fôssem cem por cento específicas, poder-se-ia afirmar que todos os casos positivos seriam, de fato, casos de sífilis. Por outro lado, se as reações fôssem sensiveis cem por cento, téríamos certeza de descobrir todos os casos de sífilis na população examinada. Infelizmente, as técnicas modernas das reações de floculação e fixação do complemento, embora muito sensiveis e específicas, ainda não o são cem por cento.

Não existe ainda nenhuma reação capaz de descobrir os sifilíticos em cem por cento dos casos. Apenas na sífilis secundária se chega a uma proporção tão elevada. Nos outros estádios da moléstia só um determinado nível é atingido, e, na sífilis primária, há até mesmo uma fase em que a sorologia é negativa.

Todas essas causas de êrro procuramos considerar em nosso trabalho, já tendo afirmado, de antemão, que os resultados encontrados não devem signifi- 
car o coeficiente exato, mas sim aproximado, da prevalência da sífilis no grupo dạ população em estudo.

\section{O PROBLEMA DAS FALSAS REACOOES POSITIVAS}

As reações sorológicas positivas em indivíduos não portadores de sífilis constituem um sério problema de interpretação e julgamento pela parte do médico. O perigo de se estabelecer um diagnóstico de sífilis em um indivíduo não sifilítico deve ser evitado a todo o custo. Ninguém deverá ser taxado de iuético enquanto o diagnóstico não puder ser comprovado.

Embora, como já foi dito, o diagnóstico da sífilis seja feito, principalmente, à custa da positividade das reações sorológicas, tais reações, no entanto, nem sempre significam a existência da infecção luética. Nas reações sorológicas utilizadas em laboratório antígenos não específicos são usados para a pesquisa de um anticorpo não específico.

Quando o homem é infectado pelo Treponema pallidum dois (e, possivelmente, mais) anticorpos são elaborados e aparecem no sôro: 1 - anticorpos específicos contra o $T$. pallidum; 2 - anticorpos não específicos, contra extratos de tecidos.

A pesquisa dos anticorpos específicos contra o T. pallidum é difícil, em virtude da falta de sucesso na obtenção de culturas em meios artificiais dêsse treponema. Que tais anticorpos humorais estão presentes pode. no entanto, ser experimentalmente demonstrado "in vivo" pela prova de proteção em animais, ou "in vitro" pela reação de imobilização, de Nelson e Meyer.

Concomitante ao aparecimento de anticorpos treponemicidas na infecção sifilítica. outros anticorpos, não específicos, são também observados. Reay̧ina é o nome que se dá ao anticorpo pesquisado nas atuais reaçôes de rotina para o diagnóstico da sífilis, a qual pode ser encontrada em pequena quantidade no sôro sanguíneo de pessoas normais, como até mesmo em animais. Essa quantidade de reagina não interfere, contudo, nos resultados das reações, porém, em algumas pessoas ela pode se encontrar em quantidade suficiente para produzir uma reação positiva na ausência da sífilis.

Reações falsas positivas não devem ser responsabilizadas apenas pela existência de reaginas inespecíficas ou por um exagêro da sensibilidade do antígeno. Podem ser devidas, ainda. a outras causas, tais como erros de técnica de laboratório, falhas grosseiras na colheita do material ete.

As reações falsas positivas de ordem técnica, podem ser devidas à limpeza pouco cuidadosa da vidraria, preparação inadequada do antígeno, erros de leitura dos resultados das reaçóes etc. Não se pode deixar de mencionar, além disso, as oportunidades de mistura, troca de tuhos ou de etiquetas, dando lugar a resultados falsos.

As reações biológicas falsamente positivas podem ter lugar em indivíduos sem nenhum sinal aparente de doença. $O$ seu conceito apareceu por volta de 1920, e em inquéritos realizados nos Estados Unidos e países escandinavos, abrangendo cêrca de 120.000 pessoas, evidenciou-se que 1 em cada 1.000 indivíduos normais apresenta exame sorológico positivo para a sifilis ${ }^{57}$. 
Segundo Stokes ${ }^{58}$, a proporção de reações biológicas falsas positivas em todas as reações (positivas e negativas), em inquéritos sorológicos, nunca excederia de 1 para 700 .

Realmente, entre os casos positivos nas primeiras 15.000 reações realizadas entre operários da capital de São Paulo, casos êsses que foram por nós examinados, encontramos vários indivíduos cujo diagnóstico de sífilis não podia ser estabelecido. por falta de sinais ou de história da moléstia, e a proporção dêsses casos, possivelmente de falsas reações positivas, foi de 1 para 800.

O tipo mais frequente de reação falsa positiva ocorre secundàriamente a uma doença ou condição especial. Essas reações inespecíficas já foram relacionadas a mais de 70 condições diferentes, entre as quais mencionaremos as espiroquetoses em geral (bouba, pinta, bejel, doença de Weil. febre recorrente etc.); algumas doenças produzidas por bactérias, tais como a lepra, tuberculose. escarlatina etc.; algumas doenças produzidas por vírus, como a mononucleose infecciosa, infecções diversas do aparelho respiratório, inclusive o resfriado comum, vacina, sarampo, linfogranuloma venéreo, hepatite infecciosa etc; algumas produzidas por protozoários, como a malária, tripanosomoses etc.

Acredita-se que a vacinação seja responsável por 10 a $35 \%$ de reaçóes falsas positivas, as quais apareceriam cêrca de 12 dias após, persistindo uma média de 3 meses, com títulos baixos. Nós acompanhamos cêrca de 100 pessoas que receberam vacinação antivariólica no Centro de Aprendizado da Faculdade de Higiene e Saúde Pública da Universidade de São Paulo e não constatamos nenhuma reação falsa positiva.

Na gravidez, segundo alguns autores, haveria positividade falsa das reacões em 1 a $3 \%$ dos casos, mas isso também é discutível.

Não há provas dignas de crédito de que o período menstrual possa ser uma causa de positividade das reações.

De todas as doenças tidas como causadoras de reações falsas positivas para a sifilis, as mais importantes, devido à alta frequência com que isso acontece, são, sem dúvida nenhuna. as treponematoses, a lepra, o impaludismo e a mononucleose infecciosa.

A fim de eliminar essas possiveis causas de êrro nos inquéritos sorológicos a que procedemos procuramos verificar a incidência dessas moléstias entre a população da capital de São Paulo.

A bouba, que se acompanha, pràticamente em $100 \%$ dos casos, de reações de fixação de complemento e de floculação positivas, é rara em todo o Estado de São Paulo. No entanto, com a imigração intensificada de nordestinos, nos últimos tempos, poderia essa moléstia constituir uma causa de êrro quanto à positividade das reações. Achamos mais prudente, por conseguinte, afastar de nossas tabulações êsses indivíduos.

Outras treponematoses, tais como a pinta e o bejel, são inexistentes na região em que procedemos ao inquérito sorológico, não merecendo por isso maiores comentários.

A lepra é a segunda moléstia, em importância, capaz de influir como causa de êrro na positividade das reaçóes. O Estado de São Paulo possui um índice 
relativamente elevado de portadores de lepra em sua população. Da ordem de 2 por 1.000 .

Os autores são unânimes em atribuir à lepra uma frequência elevada de reações positivas falsas. $\mathrm{Na}$ avaliação levada a efeito em 1935 pelos Serviços de Saúde Pública dos Estados Unidos encontrou-se positividade em casos de lepra, presumivelmente não sifilíticos, em 40 a $76 \%$ dos casos, com as reações de Hinton e Kahn presuntivos.

Na Conferência Sorológica de Washington. em 1942, a positividade obtida com soros de leprosos variou entre $14-15 \%$ com as reações de fixação de complemento e $66.70 \%$ com as reações de Hecht e Kahn presuntivo.

Faget e Ross ${ }^{59}$, em 1944, encontraram 47.3\% de reações de Kahn e Kolmer positivas em leprosos, sendo que $10,7 \%$ na forma tuberculóide e $60.6 \%$ na forma lepromatosa.

Em São Paulo, Almeida e Souza Carvalho "'t examinaram. em 1951, 152 soros de leprosos em forma lepromatosa, empregando reação de microfloculação com cardiolipina, e encontraram $46 \%$ de reações positivas ou duvidosas, sendo $27 \%$ de positivas e $19 \%$ de duvidosas.

Ainda mesmo que se admita $50 \%$ de reações falsas positivas na lepra lepromatosa deve-se observar que o coeficiente $2 / 1.000$ atribuido à população paulistana refere-se à lepra em geral, sendo a maior parte constituida de casos tuberculóides. O número de possíveis casos de lepra de forma lepromatosa encontrados em um inquérito sorológico será diminuto e a variação do coeficiente de positividade será insignificante.

O impaludismo, da mesma maneira que a tuberculose, foi motivo de muitas discussões quanto a contribuir para uma falsa positividade das reações para a sifilis. Alguns autores não encontraram reações falsas positivas na malária. Outros, ao contrário, encontraram-nas em 10 a $20 \%$ dos casos. Parece, no entanto, que o impaludismo pode ser responsável por reações falsas positivas em 4 a $16 \%$ dos casos, e de reações duvidosas até em $22 \%$ dos casos ${ }^{61}$.

Quanto à mononucleose infecciosa não encontramos dados estatísticos razoáveis quer quanto à sua influência na positividade das reações, quer quanto à sua incidência no grupo da população que nos propúnhamos examinar. Para evitar possibilidade de se colher sangue de um individuo atacado de impaludismo ou de mononucleose infecciosa foi recusado todo o sôro de pessoas portadoras de estados febris.

Falsas reações negativas

Se reações positivas podem ser encontradas em indivíduos não sifilíticos, podendo fazer variar o coeficiente em inquéritos sorológicos, para mais, por outro lado existe também, o problema das falsas reações negativas.

E' compreensível que no período de incubação da sífilis, quando os anticorpos ainda não estejam formados, ou a quantidade dêles seja diminuta, a reação sorológica seja negativa. 
Em casos raríssimos de sífilis maligna pode ser suprimida a formação de anticorpos. $\mathrm{Na}$ sífilis tardia as reações podem ser negativas devido à limitação de focos da atividade inflamatória que se acham tão circunscritos que não chegam a estimular a formação de anticorpos em quantidade suficiente para que possam ser descobertos através das reações comuns de diagnóstico. Êsses casos não ocorrem apenas na sífilis latente, mas também têm lugar em processos ativos da sífilis tardia. Acredita-se que uns 5 a $10 \%$ das lesões benignas ativas da lues tardia possam estar associados a reações negativas.

Apesar de todo o cuidado na colheita do material e do rigor da témica de laboratório, vê-se que é absolutamente impossível afastar o problema das reações falsas positivas, bem como surpreender todos os casos de sífilis nos vărios estágios da moléstia. Muitos casos em latência tardia não serão descobertos através dos inquéritos em massa. De qualquer maneira, porém, tais causas de êrro não conseguem fazer variar de maneira apreciável o coeficiente encontrido, e o verdadeiro coeficiente de prevalência da sífilis deve estar, realmente, em tôrno da percentagem obtida.

\section{MÉTODO DE TRABALHO F GRUPOS SOCIAIS ESTUDADOS}

A fim de obtermos informações a respeito do coeficiente de prẹalência da sífilis na população de São Paulo e de sua variação nos diferentes grupos sociais, fizemos as seguintes considerações.

$1^{9}$ - Os coeficientes mais elevados são encontrados, segundo a experiência de cutros autores, entre grupos sociais menos favorecidos do ponto de vista cultural e econômico.

$2^{\circ}$ - Coeficientes mais baixos, por conseguinte, são observados nos grupos sociais mais diferenciados, do ponto de vista cultural e econômico.

$3^{\circ}$ - Os mais altos índices de sífilis encontrados em uma população devem dizer respeito às prostitutas, visto que elas constituem o grupo mais exposto às doenças venéreas.

$4^{\circ}$ - Sendo a capital de São Paulo uma cidade industrial por excelência. representa a sua população operária o grupo mais importante a ser estudado. O coeficiente de prevalência da sífilis encontrado neste grupo deve ser, é de se supor, de valor médio, isto é, nem dos mais baixos nem dos mais elevados da população.

Os métodos de colheita de dados por nós utilizados foram o do exame de sangue feito de rotina e o inquérito sorológico feito em massa.

Escolhemos os estudantes da Universidade de São Paulo para o estudo do grupo social mais diferenciado do ponto de vista cultural, e o seu estudo foi feito através dos exames de rotina a que os mesmos são submetidos na Faculdade de Higiene e Saúde Pública por ocasião do seu ingresso na Universidade. 
Estudamos os soldados da Fôrça Pública do Estado de São Paulo como sendo um grupo onde os índices deveriam ser elevados, em virtude de seus característicos: população masculina, promíscua, em situação econômica e cultural pouco desenvolvida.

Os detentos da Penitenciária do Estado e as prostitutas da zona do meretrício do Bom Retiro, foram estudados como os grupos onde os índices observados devem ser considerados à parte, em virtude de seus característicos excepcionais. O desajustamento social, a ausência do senso de responsabilidade aliada à promiscuidade sexual intensa relacionam êssés dois grupos às mais elevadas taxas de sífilis e doenças venéreas de tôda a população.

Procuramos, ainda, em alguns grupos estudados, além do inquérito sorológico, fazer um interrogatório sôbre o passado venéreo dos indivíduos. Isso foi realizado entre operários, universitários e soldados. A concordância entre os coeficientes encontrados através das informações prestadas e das reações sorológicas foi muito aproximada, o que nos leva a crer que os dados por nós obtidos se aproximam, de fato, da realidade.

Nos capítulos seguintes são apresentados os resultados de nossas investigações nos grupos sociais mencionados, e procuramos, sempre que possível, estabelecer comparações com estudos semelhantes realizados entre nós por outros autores. ou em outras regiões do país e do estrangeiro.

\section{A SífILIS NA INDESTRIA}

Depois das fôrças armadas, os industriários constituem, sem dúvida nenhuma, o agrupamento humano que mais interêsse desperta, sob o ponto de vista das doenças venéreas; da sífilis, principalmente.

A importância que a sifilis representa para a Indústria pode ser fàcilmente imaginada se tivermos em mente que as complicações tardias mais frequentes dessa moléstia são aquelas que inutilizam o aparelho cárdio-vascular, o sistema nervoso e o órgão da visão.

A sifilis pode ser, portanto, responsável por acidentes graves, além de contribuir para um número elevado de operários vivendo à custa dos Institutos de Aposentadoria e Pensões, quando o seu efeito não se traduz simplesmente pelo grande número perdido de horas de trabalho.

Em tempo de guerra a sífilis pode ser incluida, por essas razões, entre os grandes sabotadores da Indústria.

Stokes ${ }^{62}$, calculando o custo em horas-homem perdidas devido à sífilis, na indústria dos Estados Unidos, apresenta o seguinte cálculo:

"Sem considerar a diminuição da eficiência, a lentidão e os graves êrros determinados pela moléstia, os efeitos do tratamento, as horas potencialmente perdidas por um indivíduo infectado e tratado, podem ser avaliadas, para a sífilis, em 300 horas-homem em 65 semanas. 
Baseado na proporção de $3 \%$ de sífilis encontrada nos operários, dentro de uma população industrial de 10.000 .000 de indivíduos... a sífilis pode custar 93.000.000 horas-homem distribuidas em 65 semanas".

Deve-se esclarecer que o cálculo de Stokes refere-se aos tratamentos antigos pelos metais.

Frequência da sífilis no meio operário

De uma maneira geral, a frequência da sífilis no meio operário varia de região para região, conforme o grau de educação e cultura do grupo observado, da sua situação econômica, e, principalmente, segundo a raça.

E' o que nos ensina a experiência norte-americana.

Stokes menciona, em seu livro, vários coeficientes encontrados nas indústrias norte-americanas, dos quais mencionaremos alguns:

$3,7 \%$ de positivos entre 24.408 indivíduos condutores de veículos e manipuladores de leite, em Seattle City, entre os anos de 1927 e 1937; 3\% em 66.015 operários de Chicago, em 1939; e 3,1\% em 11.737 operários de Oakland (Michigan), em 1938.

Em 1937, um inquérito realizado em 9 companhias de estradas. de ferro que exigiam o exame de sangue dos candidatos a emprêgo, revelava $7,8 \%$ de positividade em 21.026 examinados ${ }^{63}$.

Osborne ${ }^{64}$ calculava, de uma maneira geral, em $4 \%$ o coeficiente de sífilis para a população industrial dos Estados Unidos, em 1940, excluindo os operários negros.

Em 1942, Koch e Merrill ${ }^{65}$ encontraram $4.1 \%$ em 8.027 operários examinados na Califórnia.

Smillie ${ }^{6,6}$ apresenta as seguintes taxas para o operário norte-americano, em 1948: empregados especializados, de grande indústria, 0.6\%; empregados bran$\cos$ não especializados, de zona rural, $2,3 \%$.

Vemos que não há grande concordância entre os resultados de autores norte-americanos. De uma maneira geral, porém, os índices encontrados variam em tôrno de $3 \%$.

Foram encontradas, em algumas indústrias, percentagens elevadas, de 7 a $9 \%$; no entanto, devido à falta de maiores esclarecimentos sôbre a maneira de exame, reações utilizadas, características da população examinada etc., tais dados devem ser recebidos com reservas.

No Brasil são raros os trabalhos sôbre a sífilis na indústria. Sendo São Paulo o Estado mais industrial do país, deve ser, portanto, a região mais propícia para uma observação dêsse gênero. Muito pouca coisa, porém, foi realizada, e entre os trabalhos publicados, destacamos o inquérito sorológico que Rosa Borges (1942) realizou entre 4.200 operários de uma estamparia de Sorocaba, encontrando $17,3 \%$ de $\operatorname{casos}$ positivos $^{67}$. 


\section{A sifilis entre os operários de São Paulo (*)}

No início do ano de 1950, por sugestão de Geraldo de Paula Souza. foi criado no Serviço Social da Indústria de São Paulo um serviço especializado. destinado a descobrir e a tratar os casos de sífilis entre os operários.

Através dêsse Serviço foi possível, pela primeira vez no Brasil, a realização de um inquérito sorológico para o diagnóstico da sífilis, de grandes proporções.

Inútil será ressaltar a importância de um inquérito dessa natureza em uma cidade, como São Paulo, onde a massa operária constitui o grupo mais importante da população.

O Serviço de Sífilis do SESI procurou, desde o início, descobrir o maior número possível de casos de sífilis entre os industriários, através de dois processos, principalmente: educação sanitária e inquérito sorológico.

Não houve nenhum critério seletivo em relação às fábricas que deviam ser visitadas. Procurou-se, apenas, começar por aquelas de maior número de operários, a fim de poupar tempo e trabalho aos enfermeiros. Estes eram enviados às fábricas. onde procuravam tirar sangue de todos, ou pelo menos da maioria dos operários.

As amostras de sangue eram enviadas, em seguida, para os laboratórios médicos do SESI, onde se procedia à reação de Wassermann. Todos os sôros apresentando reações duvidosas ou positivas eram enviados ao laboratório do Departamento de Microbiologia da Faculdade de Medicina de São Paulo. onde o Dr. José de Almeida realizava a reação de Wassermann quantitativa, pela técnica de Maltamer.

Para verificar a sensibilidade dos antígenos utilizados nos laboratórios do SESI. bem como a qualidade da técnica dos sorologistas, inúmeras amostras de sôro foram enviadas ao Instituto Adolfo Lutz, onde foram realizadas reações de Wassermann. Kahn e VDRL. sendo os resultados. pràticamente. concordes em $100 \%$ dos casos.

Até abril de 1951 haviam sido visitadas 130 fábricas da capital paulista, das mais variadas indústrias, e situadas nos mais diversos bairros. Não houve preferência por nenhum tipo de indústria. nem por nenhum setor da cidade. de maneira a evitar. o mais possivel. qualquer seleção da amostra a ser txaminada.

Os operários com reaçoes positivas eram examinados nas próprias fábricas. a fim de ser estabelecido o diagnótico de sífilis.

Infeliznzte, como nem todos os operários puderam ser examinados clinicamente, pois muitos dêles são altamente instáveis em relação ao emprêgo, e já haviam abandonado a fábrica quando os procurávamos, não pudemos tabular os dados. utilizando apenas os diagnósticos dos operários examinados. e excluirido. dessa maneira, os casos de falsas reações positivas.

$\left(^{*}\right)$ 'T'rabalho realizado com a colaboração da Educadora Sanitária Yolanda Teixeira e dos Acadêmicos de Medicina Manuel B. Avila, Paulo C. Branco e Walter Belda. Devemos mencionar, ainda, o nome do Dr. Sebastião A. P. Sampaio, pela colaboração durante o estudo dos 8.000 primeiros casos. 
Consideramos, em nossa observação, como sendo sifilítico todo o operário apresentando reação sorológica positiva. Aliás, a experiência em relação aos operários após exame físico mostrou que o número de falsas reações é mínimo, e que, na realidade, uma reação positiva indica, quase sempre a presença da sifilis.

Durante o período de fevereiro de 1950 a abril de 1951 foram examinados $20.8 \dot{9} 2$ operários na capital de São Paulo, os quais apresentaram um coeficiente de positividade para a sífilis igual a $3,8 \%$.

Às vezes o operário pedia para que os membros de sua família se submetessem ao exame de sangue, razão pela qual algumas crianças foram incluidas em nossas estatísticas. De uma maneira geral, porém, a idade dos indivíduos examinados variava de 15 a 65 anos.

Dos 20.892 operários examinados $64,3 \%$ era do sexo masculino, $90 \%$ de côr branca e $89,5 \%$ de brasileiros.

A distribuição do coeficiente de positividade foi a seguinte:

\begin{tabular}{|c|c|c|c|}
\hline Sexo & Pitaminados & $R W \cdot$ positiva & $\%$ \\
\hline Homens $\quad \ldots \ldots \ldots \ldots \ldots$ & 13.453 & 590 & 4,39 \\
\hline$\ldots \ldots \ldots \ldots$ & 7.439 & 207 & 2,78 \\
\hline Cor & Examinades & $R W \cdot$ positiva & $\%$ \\
\hline$\ldots \ldots \ldots \ldots$ & 18.817 & 611 & 3,25 \\
\hline Pardos $\quad \ldots \ldots \ldots \ldots \ldots \ldots$ & 1.158 & 102 & 8,81 \\
\hline$\ldots \ldots \ldots \ldots \ldots$ & 892 & 84 & 9,42 \\
\hline Amarelos $\quad \ldots \ldots \ldots \ldots \ldots$ & 2.5 & - & - \\
\hline Estado ciril & Ficaminados & $R W \cdot$ positive & $\%$ \\
\hline Solteiros $\quad \ldots \ldots \ldots \ldots \ldots$ & 11.027 & 308 & 2,79 \\
\hline$\ldots \ldots \ldots \ldots \ldots$ & 9.449 & 462 & 4,89 \\
\hline$\ldots \ldots \ldots \ldots \ldots$ & 412 & 27 & 6,55 \\
\hline Não especificados ...... & 4 & - & 一 \\
\hline Nacionalidade & Examinados & $R W$. positize & $\%$ \\
\hline Brasileiros $\quad \ldots \ldots \ldots \ldots$ & 18.716 & 734 & 3,92 \\
\hline Estrangeiros & 2.176 & 63 & 2,90 \\
\hline
\end{tabular}

O fato mais importante a nos chamar a atenção é o coeficiente de positividade relativamente baixo.

Constituindo a classe operária uma grande parte da população paulistana e, supondo-se que outros grupos de nível cultural e econômico mais elevado apretem, no máximo, coeficientes semelhantes, é de se esperar que o coeficiente de prevalência da sífilis na capital de São Paulo não seja muito elevado.

Apresentaremos, em seguida, quadros onde os dados obtidos em nosso trabalho são apresentados com maiores pormenores. 


\author{
INQUÉRITO SOROLÓGICO PARA O DIAGNÓSTICO DA \\ SIFILIS, REALIZADO ENTRE 20.892 OPERÁRIOS DA \\ CAPITAL DE SÃo PAULO, ENTRE FEVEREIRO DE \\ 1950 E ABRIL DE 1951
}

Distribuição da positividade das reações segundo

$$
\begin{aligned}
& a-\text { IDADE } \\
& b-\text { côr } \\
& \text { c - sexo } \\
& \text { d - ESTAdo CIVIL } \\
& \text { e - NACION ALIDADE }
\end{aligned}
$$




\section{QUADRO I}

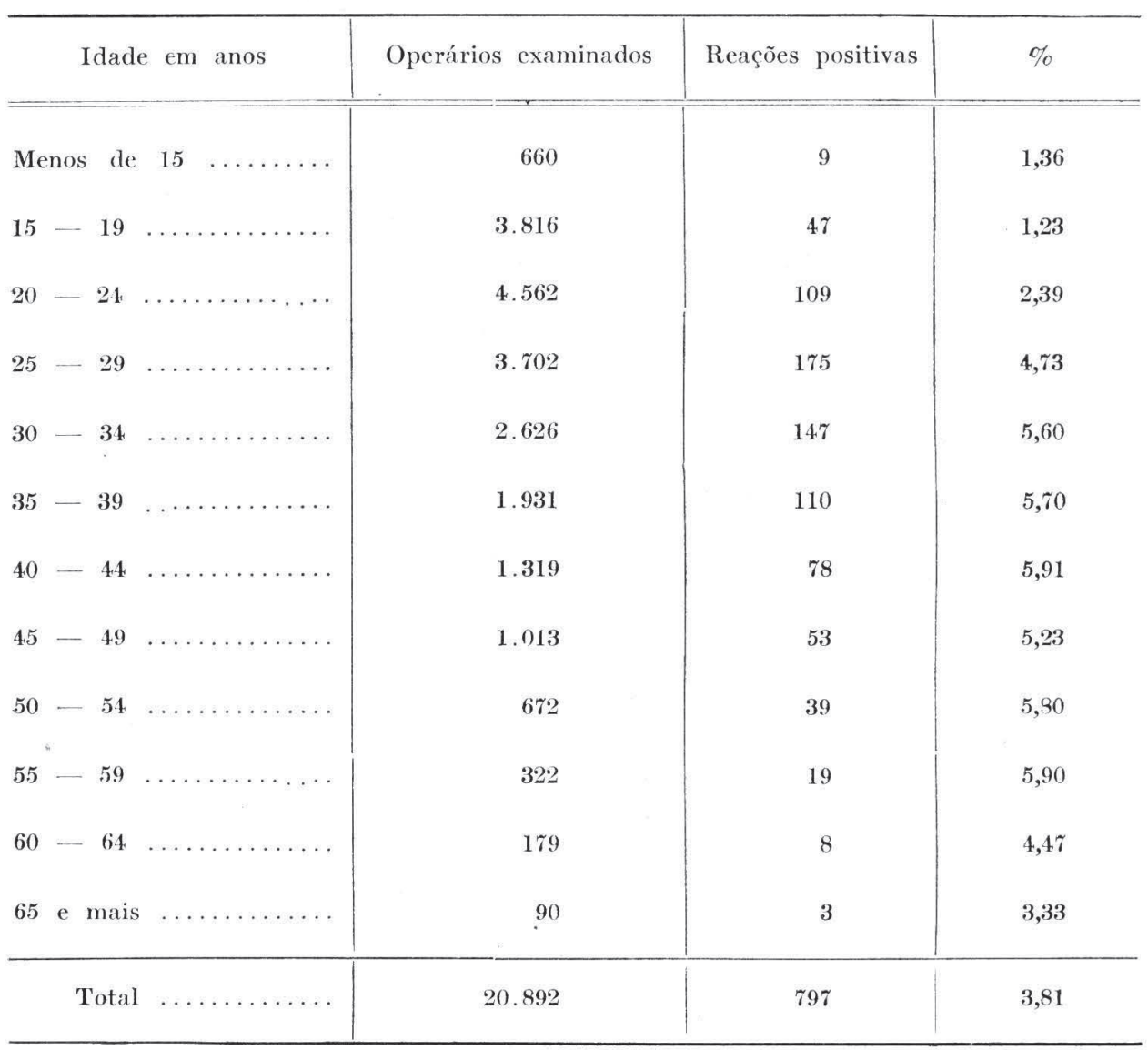


BARROS, J. M. de - CONTRIBUIÇÃO PARA O ESTUDO DO...

31

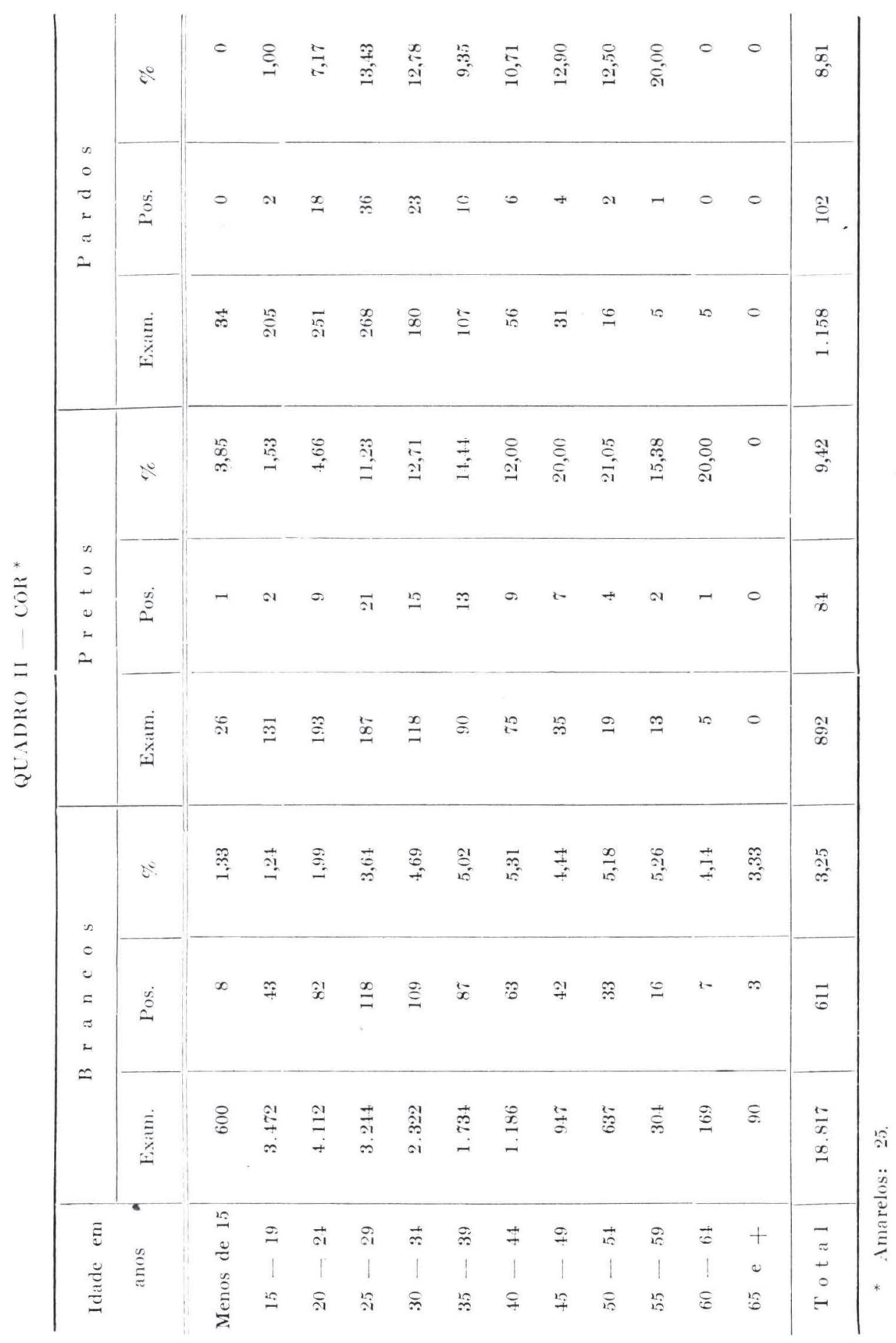


QUADRO III - SEXO

\begin{tabular}{|c|c|c|c|c|c|c|}
\hline \multirow{2}{*}{$\begin{array}{c}\text { Idade em } \\
\text { anos }\end{array}$} & \multicolumn{3}{|c|}{$\mathrm{Homens}$} & \multicolumn{3}{|c|}{$\mathrm{Mulheres}$} \\
\hline & Exam. & Pos. & $\%$ & Exam. & Pos. & $\%$ \\
\hline Menos de 15 & 268 & 2 & 0,75 & 392 & 7 & 1,79 \\
\hline $15-19$ & 1.556 & 21 & 1,35 & 2.260 & 26 & 1,15 \\
\hline $20-24$ & 2.615 & 73 & 2,79 & 1.947 & 36 & 1,85 \\
\hline $25-29$ & 2.681 & 131 & 4,89 & 1.021 & 44 & 4,31 \\
\hline $30-34$ & 1.953 & 111 & 5,68 & 673 & 36 & 5,35 \\
\hline $35-39$ & 1.360 & 79 & 5,81 & 570 & 30 & 5,26 \\
\hline $40-44$ & 1.035 & 61 & 5,89 & 285 & 18 & 6,32 \\
\hline $45-49$ & 838 & 47 & 5,61 & 175 & 6 & 3,43 \\
\hline $50-54$ & 600 & 36 & 6,00 & 72 & 3 & 4,17 \\
\hline $55-59$ & 292 & 19 & 6,51 & 30 & 0 & 0 \\
\hline $60-64$ & 172 & 7 & 4,07 & 7 & 1 & 14,29 \\
\hline $65 \mathrm{e}+$ & 83 & 3 & 3,61 & $\gamma$ & 0 & 0 \\
\hline Tot a $\mathrm{I}$ & 13.453 & 590 & 4,39 & 7.439 & 207 & 2,78 \\
\hline
\end{tabular}




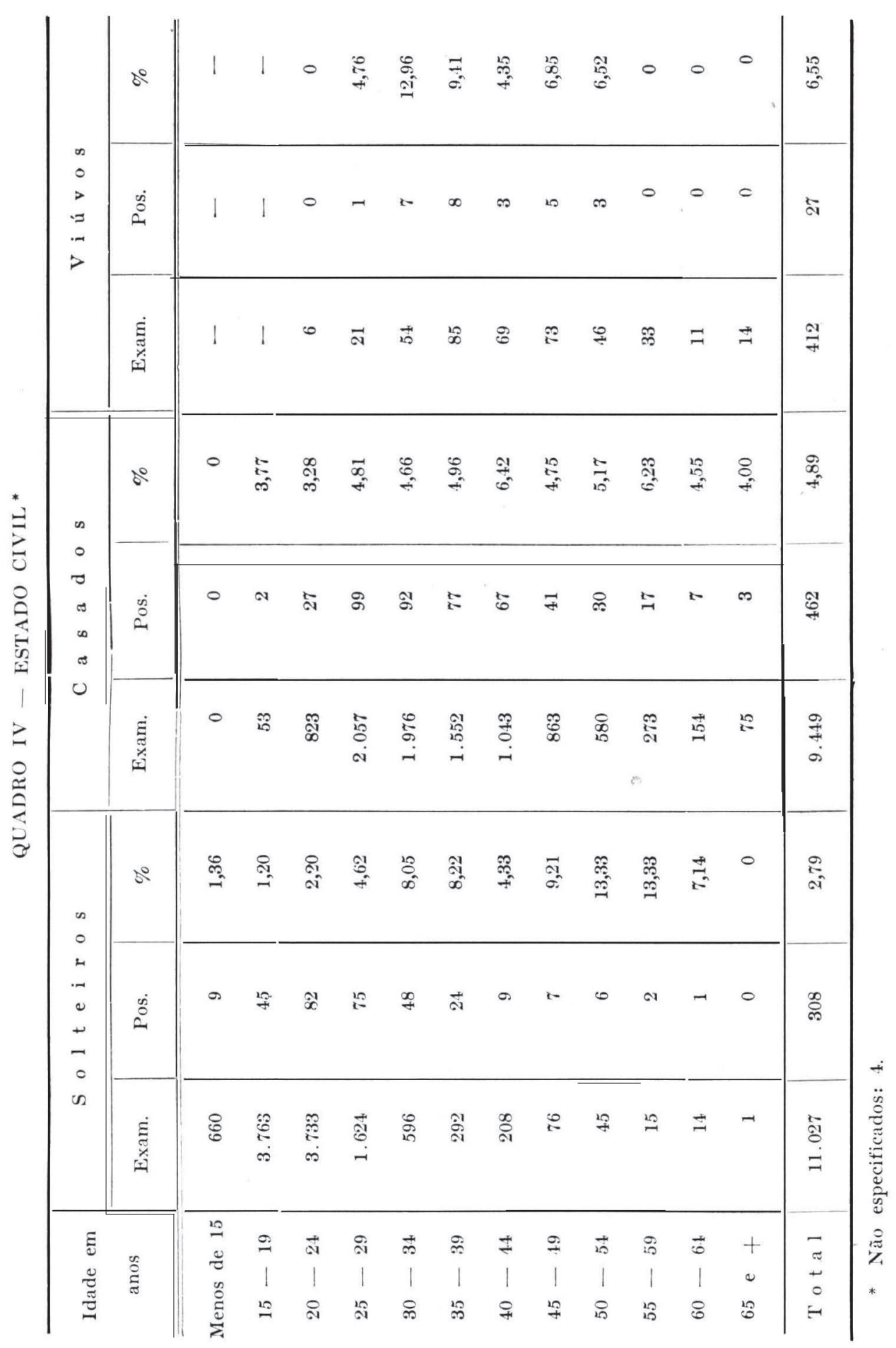


QUADRO V - NACIONALIDADE

\begin{tabular}{|c|c|c|c|c|c|c|}
\hline \multirow{2}{*}{$\begin{array}{l}\text { Idade em } \\
\text { anos }\end{array}$} & \multicolumn{3}{|c|}{ B r a s i l e i r o s } & \multicolumn{3}{|c|}{ Es t r a n g e i r o s } \\
\hline & Exam. & Pos. & $\%$ & Exam. & Pos. & $\%$ \\
\hline Menos de 15 & 657 & 9 & 1,37 & 3 & 0 & 0 \\
\hline $15 \ldots 19$ & 3.767 & 47 & 1,25 & 49 & 0 & 0 \\
\hline $20-24$ & 4.469 & 108 & 2,42 & 93 & 1 & 1,08 \\
\hline $25-29$ & 3.472 & 168 & 4,84 & 230 & 7 & 3,04 \\
\hline $30-34$ & 2.405 & 142 & 5,90 & 221 & 5 & 2,26 \\
\hline $35-39$ & 1.632 & 103 & 6,31 & 298 & 6 & 2,01 \\
\hline $40-44$ & 981 & 70 & 7,14 & 339 & 9 & 2,65 \\
\hline $45-49$ & 706 & 43 & 6,09 & 307 & 10 & 3,26 \\
\hline $50-54$ & 408 & 24 & 5,88 & 264 & 15 & 5,68 \\
\hline $55-59$ & 141 & 14 & 9,93 & 181 & 5 & 2,76 \\
\hline $60-64$ & 64 & 5 & 7,81 & 115 & 3 & 2,61 \\
\hline $65 \mathrm{e}+$ & 14 & 1 & 7,14 & 76 & 2 & 2,63 \\
\hline T o t a l & 18.716 & 734 & 3,92 & 2.176 & 63 & 2,90 \\
\hline
\end{tabular}


INQUÉRITO SOROLÓGICO PARA O DIAGNÓSTICO DA SIFILIS, REALIZADO ENTRE 13.453 OPERÁRIOS DO SEXo Masculino, DA CAPITAL DE SÃO PAUlo, ENTRE FEVEREIRO DE 1950 E ABRIL DE 1951

Distribuição da positividade das reações segundo

$$
\begin{aligned}
& a-\text { côr } \\
& b-\text { estado civil } \\
& \text { c - Nacionalidade }
\end{aligned}
$$




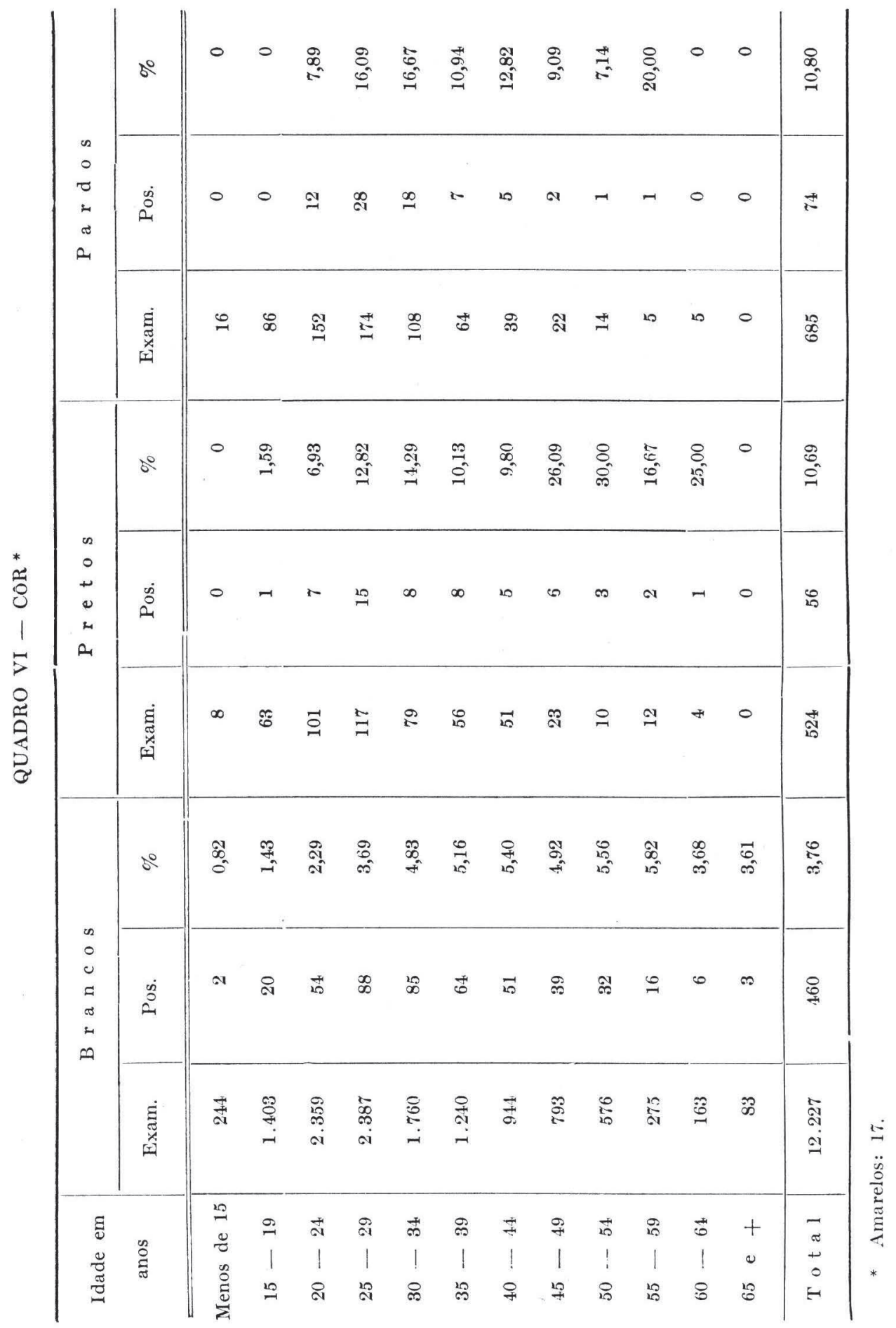




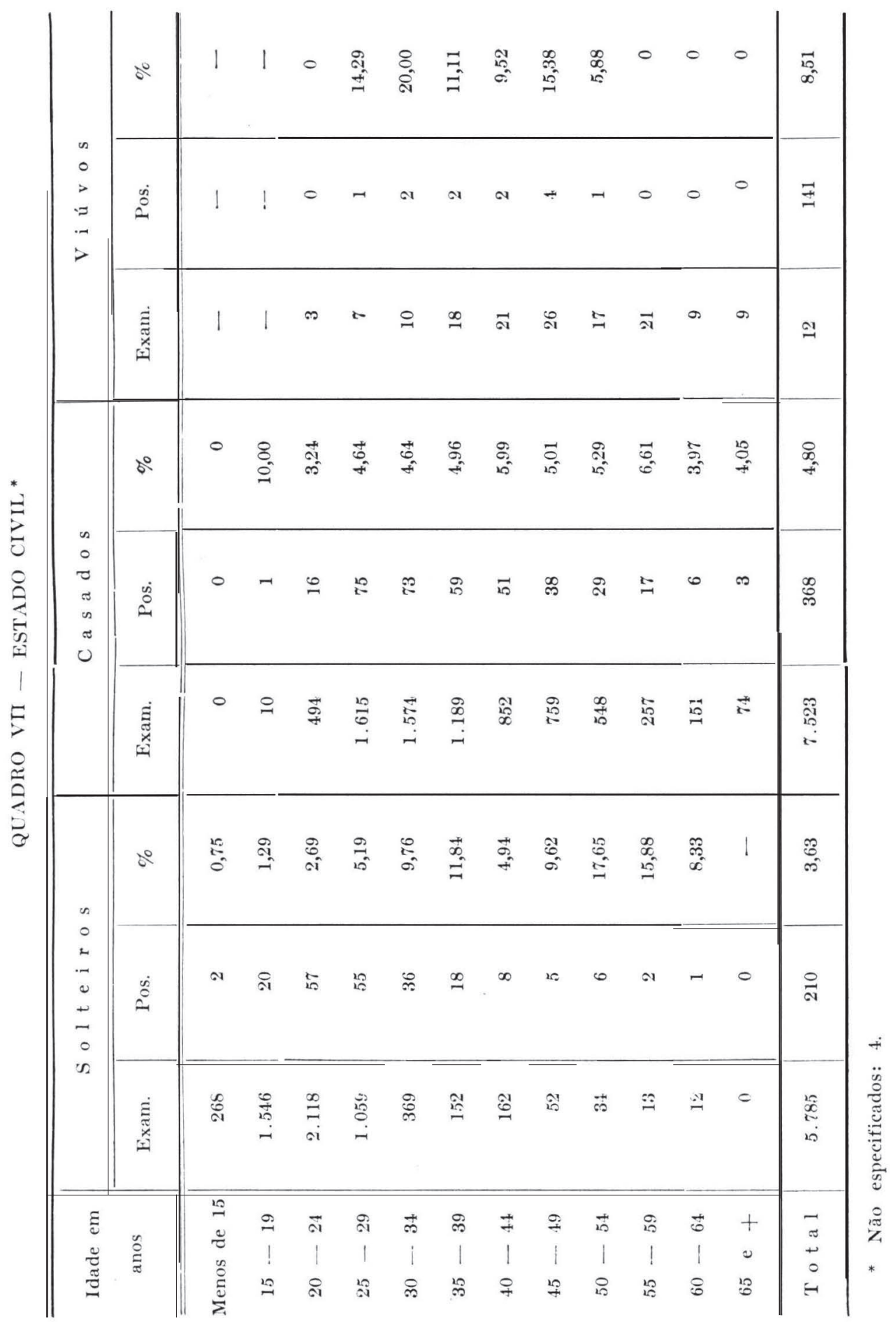


QUADRO VIII - NACIONALIDADE

\begin{tabular}{|c|c|c|c|c|c|c|}
\hline \multirow{2}{*}{$\begin{array}{c}\text { Idade em } \\
\text { anos }\end{array}$} & \multicolumn{3}{|c|}{$\mathrm{B}$ r a s i l e i r o s } & \multicolumn{3}{|c|}{ Est r a n g e r o s } \\
\hline & Exam. & Pos. & $\%$ & Exam. & Pos. & $\%$ \\
\hline$=$ & $=$ & $=$ & & & & \\
\hline Menos de 15 & 267 & 2 & 0,75 & 1 & 0 & . \\
\hline $15-19$ & 1.532 & 21 & 1,37 & 24 & 0 & 0 \\
\hline $20-24$ & 2.552 & 72 & 2,82 & 63 & 1 & 1,59 \\
\hline $25-29$ & 2.514 & 127 & 5,05 & 167 & 4 & 2,40 \\
\hline $30-34$ & 1.774 & 108 & 6,09 & 179 & 3 & 1,68 \\
\hline $35-39$ & 1.138 & 73 & 6,41 & 222 & 6 & 2,70 \\
\hline $40-44$ & 750 & 52 & 6,93 & 285 & 9 & 3,16 \\
\hline $45-49$ & 574 & 37 & $6,4.5$ & 264 & 10 & 3,79 \\
\hline $50-54$ & 358 & 21 & 5,87 & 242 & 15 & 6,20 \\
\hline $55-59$ & 127 & 14 & 11,02 & 165 & 5 & 3,03 \\
\hline $60-64$ & 60 & 4 & 6,67 & 112 & 3 & 2,68 \\
\hline $65 \mathrm{e}+$ & 10: & 1 & 10,00 & 73 & 2 & 2,74 \\
\hline $\mathbf{T} \circ \mathrm{t}$ a $\mathbf{l}$ & 11.656 & 532 & 4,56 & 1. 797 & 58 & 3,23 \\
\hline
\end{tabular}


INQUÉRITO SOROLÓGICO PARA O DIAGNÓSTICO DA

SIFILIS, REALIZADO ENTRE 7.439 OPERÁRIOS DO

SEXO FEMININO, DA CAPITAL DE SÃO PALlO, ENTRE

FEVEREIRO DE 1950 E ABRIL DE 1951

Distribuição da positividade das reações segundo

$$
\begin{aligned}
& a-\text { côr } \\
& \text { b - estado civiL } \\
& \text { c - Nacionalidade }
\end{aligned}
$$




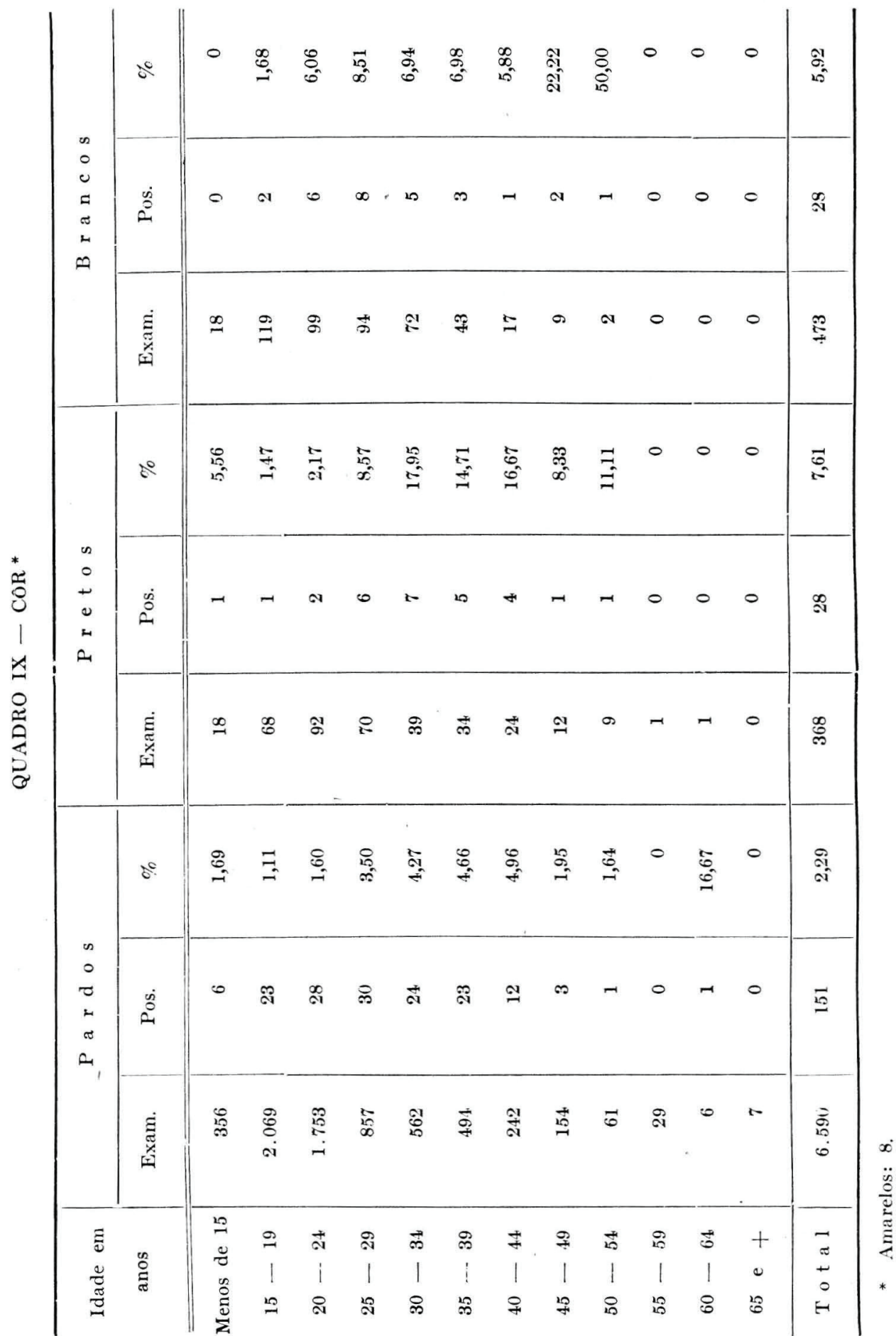




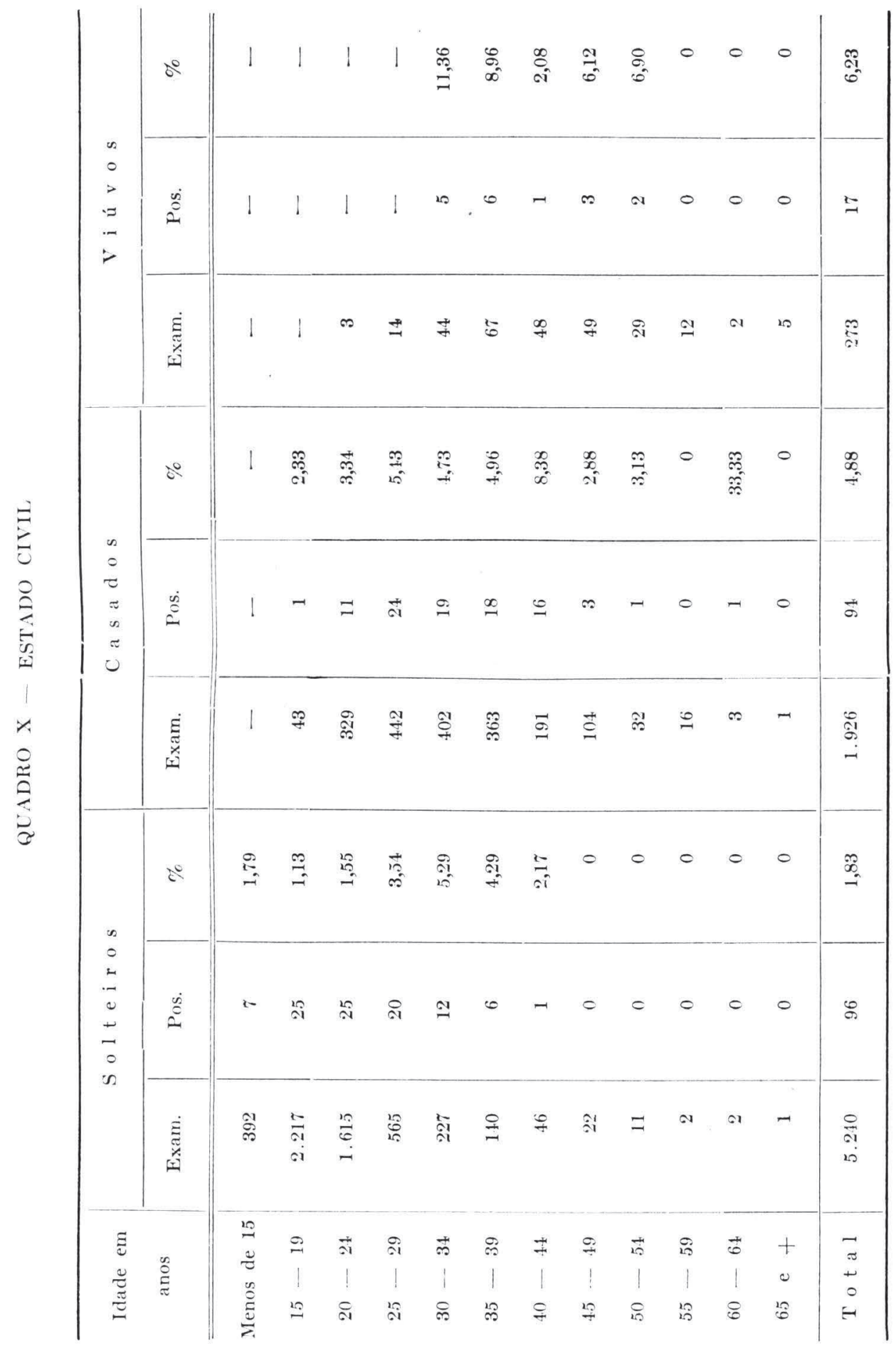


QUADRO XI - NACIONALIDADE

\begin{tabular}{|c|c|c|c|c|c|c|}
\hline \multirow{2}{*}{$\begin{array}{l}\text { Idade em } \\
\text { anos }\end{array}$} & \multicolumn{3}{|c|}{ Estrang e i ros } & \multicolumn{3}{|c|}{$\mathrm{B} r$ a s i l e $\mathrm{i}$ ros } \\
\hline & Exam. & Pos. & $\%$ & Exam. & Pos. & $\%$ \\
\hline Menos de 15 & 390 & 7 & 1,79 & 2 & 0 & () \\
\hline $15-19$ & 2.235 & 26 & 1,16 & 25 & 0 & 0 \\
\hline $20-24$ & 1.917 & 36 & 1,88 & 30 & 0 & 0 \\
\hline $25-29$ & 958 & 41 & 4,28 & 63 & 3 & 4,76 \\
\hline $30-34$ & 631 & 34 & 5,39 & 42 & 2 & $4, \pi ; j$ \\
\hline $35-39$ & 494 & 30 & 5,07 & 76 & 0 & 0 \\
\hline $40-44$ & 231 & 18 & 7,79 & 54 & 0 & 0 \\
\hline $45-49$ & 132 & 6 & 4,55 & 43 & 0 & 0 \\
\hline $50-54$ & 50 & 3 & 6,00 & 22 & 0 & 0 \\
\hline $55-59$ & 14 & 0 & 0 & 16 & 0 & 0 \\
\hline $60-64$ & 4 & 1 & $25,00^{\circ}$ & 3 & 0 & 0 \\
\hline $65 \mathrm{e}+$ & 4 & 0 & 0 & 3 & 0 & 0 \\
\hline $\mathrm{T} o \mathrm{t}$ a $\mathrm{I}$ & 7.060 & 202 & 2,86 & 379 & 5 & 1,32 \\
\hline
\end{tabular}

\section{A IMPORTANCIA DO FATOR IDADE NO INQUERITO SOROLGGICO} REALI\%ADO ENTRE OS OPERÁRIOS DE SÃO PAULO

As doenças venéreas incidem quase que exclusivamente na população adu!ta, sendo o contágio inocente das crianças muito raro. Em certos grupos, onde a falta de recursos médicos está associada a outros fatôres, a frequência da sífilis congênita pode ser elevada. E', no entanto, após o início das atividades sexuais que a incidência das doenças venéreas se torna digna de nota.

Kinsey ${ }^{68}$ verificou que mais de $95 \%$ da população masculina norte-americana está em atividade sexual depois dos 15 anos de idade, embora considere aquêle autor a masturbação, polução noturna etc., como atividade sexual.

Nós procuramos colher informações de 490 universitários paulistas do sexo masculino, através das fichas médicas da Faculdade de Higiene e Saúde Públi- 
ca, e verificamos que êsses jovens tiveram a primeira relação sexual no seguinte período:

$$
\begin{array}{llllllll}
\text { Entre } & 11 & \text { e } & 15 & \text { anos: } & 102 & \text { estudantes } & (20,4 \%) \\
\text { Entre } & 16 & \text { e } & 20 & \text { anos: } & 377 & \text { estudantes } & (77,4 \%) \\
\text { Entre } & 21 & \text { e } & 25 & \text { anos: } & 11 & \text { estudantes } & (2,2 \%)
\end{array}
$$

Repetindo a observação em relação ao mesmo assunto entre operários de fábricas da capital paulista, conseguimos entrevistar 646 homens cujas respostas foram:

$$
\begin{array}{llllllll}
\text { Entre } & 11 & \text { e } & 15 & \text { anos: } & 72 & \text { operários } & (11,3 \%) \\
\text { Entre } & 16 & \text { e } & 20 & \text { anos: } & 552 & \text { operários } & (81,2 \%) \\
\text { Entre } & 21 & \text { e } & 25 & \text { anos: } & 20 & \text { operários } & (4,1 \%) \\
\text { Entre } & 26 & \text { e } & 30 & \text { anos: } & 2 & \text { operários } & (0,4 \%)
\end{array}
$$

Ainda em um inquérito semelhante, realizado entre 503 soldados da Fôrça Pública de São Paulo, verificamos que êles haviam tido a primeira relação sexual nas seguintes idades:

$$
\begin{array}{lllllrlr}
\text { Entre } & 11 & \text { e } & 15 & \text { anos: } & 240 & \text { soldados } & (47,7 \%) \\
\text { Entre } & 16 & \text { e } & 20 & \text { anos: } & 259 & \text { soldados } & (51,5 \%) \\
\text { Entre } & 21 & \text { e } & 25 & \text { anos: } & 4 & \text { soldados } & (0,8 \%)
\end{array}
$$

Observamos, através de nossos inquéritos, que $98 \%$ dos estudantes e $99 \%$ dos operários e soldados iniciaram sua vida sexual antes dos 20 anos de idade, sendo que, cêrca de $50 \%$ em todos os três grupos, segundo os nossos dados, o fizeram ao redor dos 16 anos.

Realizamos também, um inquérito entre indivíduos que acusavam passado venéreo, a fim de verificar em que idade êles adquiriram, pela primeira vez, a sua infecção. O primeiro grupo foi o de universitários matriculados na $\mathrm{Fa}$ culdade de Higiene e Saúde Pública, e o resultado entre 132 estudantes revelou o seguinte:

$$
\begin{aligned}
& \text { Entre } 16 \text { e } 20 \text { anos: } 59 \text { estudantes }(44,7 \%) \\
& \text { Entre } 21 \text { e } 25 \text { anos: } 67 \text { estudantes }(50,8 \%) \\
& \text { Entre } 26 \text { e } 30 \text { anos: } 6 \text { estudantes }(4,5 \%)
\end{aligned}
$$

De 310 operários com passado venéreo, entrevistados em fábricas ou nos ambulatórios médicos do SESI, obtivemos as seguintes respostas:

$$
\begin{aligned}
& \text { Entre } 11 \text { e } 15 \text { anos: } 37 \text { operários (12.0\%) } \\
& \text { Entre } 16 \text { e } 20 \text { anos: } 114 \text { operários }(36,8 \%) \\
& \text { Entre } 21 \text { e } 25 \text { anos: } 109 \text { operários }(35,1 \%) \\
& \text { Entre } 26 \text { e } 30 \text { anos: } 30 \text { operários }(9,7 \%) \\
& \text { Entre } 31 \text { e } 35 \text { anos: } 20 \text { operários }(6,4 \%)
\end{aligned}
$$

Soldados da Fôrça Pública de São Paulo, em número de 293, forneceram as seguintes informações, em relação à primeira infecção venérea: 


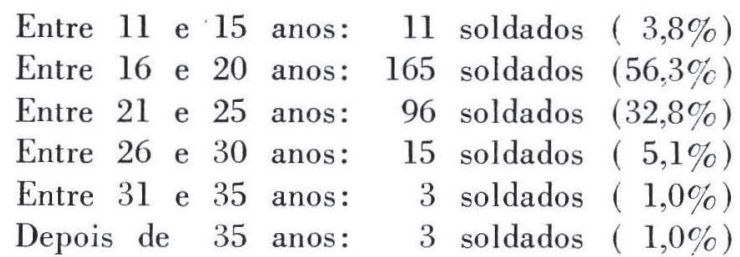

Observamos neste segundo inquérito que, 84 a $95 \%$ dos indivíduos entrevistados, acusaram a primeira doença venérea antes dos 25 anos de idade, e, ainda segundo outros dados, a maior frequência se verifica entre os 19 e 23 anos.

Se considerarmos que a sífilis é uma das doenças venéreas mais frequentes, podemos imaginar que a sua incidência nos grupos de idade seja diretamente proporcional às taxas observadas para as doenças venéreas em geral.

De fato, o resultado do inquérito sorológico realizado entre os convocados norte-amerizanos pelo Selective Service mostrou que a incidência mais elevada de sífilis se processava entre os 21 e 35 anos de idade ${ }^{69}$.

Em nosso trabalho, cujos dados estão apresentados no quadro I, relative à distribuição das taxas de reações sorológicas positivas por grupos de idade, tomamos os pontos médios das classes, por idade, e as respectivas percentagens de positividade, e procuramos testar a hipótese de que existia uma não correlação entre as variáveis observadas.

Foi encontrado um $\mathrm{r}=0,67$, coeficiente de correlação êsse que, no nível de $5 \%$, para 8 graus de liberdade, mostrou-se significante.

Rejeitamos, então, a hipótese acima, isto é, aceitamos a hipótese de uma correlação positiva entre idade e taxa de positividade das reações sorológicas para o diagnóstico da sífilis para o grupo estudado.

Analisando o quadro I, o mesmo nos sugeriu a existência de um grupo de idade (15 a 29 anos), no qual a percentagem de positividade parecia aumentar mais ràpidamente do que no segundo grupo (30 a 39 anos), onde a taxa de positividade parecia crescer de maneira menos acentuada, com tendência a permanecer constante. No terceiro grupo de idade (60 anos em diante) a faxa de positividade apresentava tendência a baixar.

Calculamos, então, os coeficientes de variação para os três grupos, os quais foram, respectivamente: $57,80 \%, 4,09 \%$ e $14,62 \%$. Esses resultados parecem confirrıar as nossas impressões sôbre a ascensão contínua da taxa de positividade sorológica, nos operários por nós estudados, até um certo grupo de idade, e depois uma relativa estabilidade.

\section{A IMPORTANCIA DO FATOR RAÇA NO INQUERITO SOROLOGICO RLALIKADO ENTRE OS OPERÁRIOS DE SÃO PAULO}

Em 18.817 operários brancos examinados encontramos 611 casos positivos $(3,25 \%)$, e em 892 operários pretos 84 positivos $(9,42 \%)$; entre 1.158 operários pardos a positividade foi de 8,81\%, isto é, em 102 casos. 
Distribuidos, quanto ao sexo e côr, apresentaram as seguintes taxas:

\begin{tabular}{l|c|c|c}
\hline & Examinados & $R W$. positiva & $\%$ \\
\hline \hline Mulheres brancas $\ldots \ldots \ldots$ & 6.590 & 151 & 2,29 \\
Mulheres pardas $\ldots \ldots \ldots$ & 473 & 28 & 5,92 \\
Mulheres pretas $\ldots \ldots \ldots$ & 368 & 28 & 7,61 \\
\hline Homens brancos $\ldots \ldots \ldots$ & 12.227 & 460 & 3,76 \\
Homens pardos $\ldots \ldots \ldots$ & 685 & 74 & 10,80 \\
Homens pretos $\ldots \ldots \ldots$ & 524 & 56 & 10,69 \\
\hline
\end{tabular}

Indiscutivelmente, a taxa de prevalência da sífilis foi muito mais elevada entre os opzerários de côr parda e preta.

Ésses resultados estão de acôrdo com aquêles encontrados pelos autores norte-americanos.

Segundo dados de 1947 (VD Fact Sheet, United States Public Health Service, Venereal Disease Division, Washington, D.C., May, 1947), a incidência da sífilis era de $1,7 \%$ para o homem branco e de $25,2 \%$ para o homem negro.

Em inquérito sorológico realizado em 1945 na cidade de Savannah. Geórgia (EE. UU.) por Bowdoin e colaboradores, foram encontradas taxas de prevalência da sífilis altamente desproporcionais, quando relacionadas às raças branca e $\operatorname{preta}^{70}$.

Foram as seguintes as taxas observadas:

\begin{tabular}{|c|c|c|c|}
\hline & & Examinados & $R W \cdot$ positiva \\
\hline Mulheres brancas & $\ldots \ldots \ldots \ldots \ldots \ldots \ldots$ & 13.937 & $2,3 \%$ \\
\hline Mulheres pretas & $\ldots \ldots \ldots \ldots \ldots \ldots \ldots \ldots$ & $20.8 \% 2$ & $30,3 \%$ \\
\hline Homens brancos & $\ldots \ldots \ldots \ldots \ldots \ldots \ldots$ & 12.402 & $3,4 \%$ \\
\hline Homens pretos & $\ldots \ldots \ldots \ldots \ldots \ldots$ & 16.602 & $31,5 \%$ \\
\hline
\end{tabular}

Em 1919, também na Geórgia, através de exame de sangue feito na população de Studytown, foi observada uma percentagem de $0,6 \%$ de reações positivas ou duvidosas para os brancos, e $13,5 \%$ para os pretos ${ }^{71}$.

Nós encontramos a mesma discordância entre as taxas de prevalência de sífilis entre os brancos e os não brancos, tal como acontece nos Estados Unidos. Indiscutivelmente, há uma maior percentagem de reaçôes positivas entre os indivíduos pardos e negros. Apenas a diferença observada não obedece à mesma proporção que aquela encontrada entre os norte-americanos. 
Enquanto que nos Estados Unidos a diferença verificada é, pelo menos, 10 vezes mais elevada entre os pretos, em relação aos brancos, nós encontramos uma diferença que não chega a 3 vezes entre brancos e não brancos, isto é, pardos e pretos.

Entre os fatôres tidos como responsáveis pela maior incidência da sífilis e outras doenças venéreas entre indivíduos da raça negra, a diferença econômica e educacional é o mais importante, segundo os autores norte-americanos.

Talvez se possa explicar essa menor diferença entre as taxas de prevalência da sifilis para o operário branco e preto, observada em nosso trabalho, pelo fato de não haver preconceito de raça entre o nosso povo, vivendo o operário negro em condições de vida muito semelhantes àquelas do operário branco, o que não acontece nos Estados Unidos.

Seria necessário estudar, entretanto, tôdas as condições de vida do operário branco e não branco, entre nós, para ver até que ponto elas são responsáveis pela diferença encontrada.

A importância do fator econômico em relação às doenças venéreas foi motivo de um trabalho de Usilton e Ruhland, em Washington, D.C., em $1939^{72}$. Chegaram êsses autores à conclusão seguinte:

Taxa de doenças venéreas

Indivíduos com rendimento anual inferior a 1.000 dólares $\quad 3,46 \%$

Indivíduos com rendimento anual de 1.000 a 3.000 dólares $\quad 0,64 \%$

Indivíduos com rendimento anual de mais de 3.000 dólares $\quad 0,47 \%$

Esses autores mostraram, também, que a incidência da sifilis é mais elevada entre brancos ou pretos, de pequeno rendimento anual.

Jason ${ }^{73}$, Leman ${ }^{74}$ e outros, demonstraram que os indivíduos de raça negra, com rendimentos anuais superiores à média de sua raça, apresentavam uma taxa de sífilis muito menor do que os demais; da mesma ordem que aquela encontrada entre os brancos.

Também uma das conclusões de Bowdoin e seus colaboradores no inquérito sorológico realizado em Savannàh, foi a de que um baixo nível econômico e social estava relacionado a uma taxa de sífilis mais elevada.

Dal Molin ${ }^{75}$, em 245 menores de côr branca e 177 de côr preta, examinados entre 1948 e 1951 no Instituto Modelo de Menores de São Paulo, encontrou, pràticamente, a mesma taxa de positividade das reações de Wassermann e Kahn em ambos os grupos, isto é, cêrca de $4 \%$.

Em nosso trabalho não pudemos apresentar nenhuma contribuição sôbre êsse assunto porque não foram colhidos dados a respeito da situação econômica ou educacional dos operários examinados.

A IMPOR'TANCIA DO FA'TOR SEXO NO INQUERITO SOROLógICO

REALI\%ADO ENTRE OS OPLRÁRIOS DE SÃO PAULO

Em 13.453 homens examinados encontramos 590 casos positivos, ou seja 4,39\%. Em 7.439 mulheres examinadas a percentagem de positividade foi de 2,78 . 
Distribuidos, quanto à côr, encontramos as proporções abaixo:

\begin{tabular}{|c|c|c|c|}
\hline & Examinados & $R W \cdot$ positiva & $\%$ \\
\hline Mulheres brancas ...... & 6.590 & 151 & 2,29 \\
\hline Homens brancos $\ldots . .$. & 12.227 & 460 & 3,76 \\
\hline Mulheres pardas ........ & 473 & 28 & 5,92 \\
\hline Homens pardos $\ldots \ldots \ldots$ & 685 & 74 & 10,80 \\
\hline Mulheres pretas ...... & 368 & 28 & $\tau, 61$ \\
\hline Homens pretos ........ & 524 & 56 & 10,69 \\
\hline Homens amarelos ...... & 17 & - & - \\
\hline Mulheres amarelas ..... & 8 & - & - \\
\hline
\end{tabular}

Bowdoin encontrou em sua observação, na Geórgia, a seguinte relação:

\begin{tabular}{|c|c|c|}
\hline & Examinados & $R W \cdot$ positiva \\
\hline Mulheres brancas $\ldots \ldots \ldots \ldots \ldots \ldots \ldots$ & 13.937 & $2,3 \%$ \\
\hline Homens brancos $\ldots \ldots \ldots \ldots \ldots \ldots \ldots$ & 12.402 & $3,4 \%$ \\
\hline Mulheres pretas $\ldots \ldots \ldots \ldots \ldots \ldots \ldots$ & 20.872 & $30,3 \%$ \\
\hline$\ldots \ldots \ldots \ldots \ldots \ldots \ldots \ldots$ & 16.602 & $31,5 \%$ \\
\hline
\end{tabular}

A maior taxa de prevalência em relação à população masculina é confirmada, estatisticamente, em nosso trabalho. E' interessante notar que os dados coincidem com os dos autores norte-americanos em relação à população branca. Quanto aos negros as taxas encontradas na Geórgia são, positivamente, muito mais elevadas do que as verificadas entre nós.

A análise da distribuição da sífilis mostrou uma maior prevalência em relação aos homens do que entre as mulheres $\left(\chi^{2}=35,54\right.$, significante ao nivel de $5 \%$, a $1^{\circ}$ de liberdade). Essa observação também foi verificada nos Estados Unidos por Detweiler.

Diehl encontrou uma taxa ligeirameite mais elevada para a mulher do que entre os homens, em 5.000 estudantes de universidade norte-americana, em 1930

No Centro de Aprendizado da Faculdade de Higiene e Saúde Pública da Universidade de São Paulo foram realizadas em 1950, 1.762 reações de Wassermann e Kahn em indivíduos maiores de 15 anos, e cujo resultado foi o seguinte: 


$\begin{array}{lccc} & \text { Examinados } & R W . \text { positivas } & \% \\ \text { Homens } & 541 & 41 & 7,57 \\ \text { Mulheres } & 1.221 & 68 & 5,56\end{array}$

No caso da Faculdade de Higiene não é difícil a explicação das diferenças de taxas encontradas. Em geral os homens não se matriculam em um centro de saúde a não ser que tenham necessidade de exames ou tratamento, o que não acontece com um grande número de mulheres. Elas procuram o centro de saúde para exame pré-natal, curso de noivas e de mãezinhas, para matricular seus filhos etc. Isto significa uma maior seleção da amostra da população masculina em relação à sífilis do que a verificada na população feminina.

Quanto às menores taxas encontradas entre as operárias, em nosso inquérito, julgamos que sejam devidas ao grande número de solteiras existentes no grupo. Cêrca de $70 \%$ das mulheres eram solteiras, apresentando uma taxa de $1,83 \%$, enquanto que a taxa de positividade das mulheres casadas era de $4,88 \%$.

Devemos nos lembrar que a taxa de positividade para a sífilis encontrada para o operário do sexo masculino, de um modo geral, foi de 4,39\%.

A IMPOR'TANCIA DO FATOR ESTADO CIVIL NO INQUÉRTO SOROLOGICO

REALIKADO ENTRE OS OPERARIOS DE SÃO PAULO

Bowdoin e colaboradores encontraram no inquérito sorológico realizado na Geórgia (Savannah), em 1945, as seguintes taxas de prevalência de sífilis, levando em conta o estado civil da população examinada:

\begin{tabular}{|c|c|c|c|c|}
\hline & \multicolumn{2}{|c|}{$\mathrm{H}$ o $\mathrm{men} \mathrm{s}$} & \multicolumn{2}{|c|}{ M u 1 heres } \\
\hline & Brancos & Pretos & Brancas & Pretas \\
\hline Casados $\quad \ldots \ldots \ldots \ldots \ldots \ldots$ & $3,2 \%$ & $35,6 \%$ & $2,6 \%$ & $32,3 \%$ \\
\hline Solteiros $\quad \ldots \ldots \ldots \ldots \ldots \ldots \ldots$ & $4,4 \%$ & $38,9 \%$ & $1,4 \%$ & $36,6 \%$ \\
\hline Viúvos $\quad \ldots \ldots \ldots \ldots \ldots \ldots \ldots$ & $9,6 \%$ & $41,5 \%$ & $3,6 \%$ & $43,4 \%$ \\
\hline Divorciados ou separados ..... & $7,0 \%$ & $44,7 \%$ & $7,1 \%$ & $43,7 \%$ \\
\hline
\end{tabular}

Nós encontramos, em nosso trabalho, a seguinte distribuição dos coeficientes de positividade da reação de Wassermann:

\begin{tabular}{|c|c|c|c|c|c|c|c|}
\hline & & \multicolumn{3}{|c|}{$\mathrm{H} \circ \mathrm{m}$ e $\mathrm{ns}$} & \multicolumn{3}{|c|}{$\mathrm{Mulh}$ e $\mathrm{res}$} \\
\hline & & Exam. & RW. pos. & $\%$ & Exam. & RW. pos. & $\%$ \\
\hline Solteiros & . & 5.785 & 210 & 3,63 & 5.240 & 96 & 1,83 \\
\hline Casados & $\ldots$ & 7.523 & 368 & 4,80 & 1.926 & 94 & 4,88 \\
\hline Viúvos & $\ldots$ & 14.1 & 12 & 3,51 & 273 & 17 & 6,23 \\
\hline
\end{tabular}


Em relação às mulheres é fàcilmente compreensível que os índices sejam, respectivamente, mais elevados em se tratando de solteiras, casadas ou viúvas.

Quanto aos homens, parece estranho, à primeira vista, que os casados tenham coeficiente mais elevado do que os solteiros. Isso pode ser explicado, se lembrarmos que os operários casados são mais idosos, já trazem do tempo de solteiro a infecção luética, além da chance de adquirí-la após o casamento. Em sua grande maioria são portadores de sífilis no período latente tardio.

Em relação aos viúvos, quando comparados aos casados, a diferença observada não foi considerada significante sob o ponto de vista estatístico.

\section{INFLUENCIA DO FATOR NACIONALIDADE NO INQUERITO SOROLǴGICO \\ REALIZADO ENTRE OS OPERÁRIOS DE SÃO PAULO}

Encontramos em nosso trabalho as seguintes taxas de positividade sorológica para operários brasileiros e estrangeiros:

\begin{tabular}{|c|c|c|c|c|c|c|}
\hline & \multicolumn{3}{|c|}{ Hom e n s } & \multicolumn{3}{|c|}{ M u l he res } \\
\hline & Exam. & RW. pos. & $\%$ & Exam. & RW. pos. & $\%$ \\
\hline Bras. ..... & 11.656 & 532 & 4,56 & 7.060 & 202 & 2,86 \\
\hline Estr. . . . . & 1.797 & 58 & 3,23 & 379 & 5 & 1,32 \\
\hline
\end{tabular}

Notamos que a taxa é ligeiramente mais elevada entre os operários brasileiros, mesmo se compararmos a percentagem encontrada entre estrangeiros e operários brancos brasileiros, que são, respectivamente, 2,90 e 3,25 ( $\chi^{2}=6,39$ significante ao nível de $5 \%$ ).

Entre os operários estrangeiros destacam-se os de nacionalidade espanhola como constituindo a maioria. Vêm em seguida os de nacionalidade italiana e depois os portuguêses.

Diversas nacionalidades estão representadas entre os indivíduos por nós examinados porém em proporções mínimas comparadas àquelas observadas em relação aos espanhóis, italianos e portuguêses.

\section{A SifILIS ENTRE OS ESTUDANTES}

Uma das verificações mais importantes do estudo de Kinsey ${ }^{56}$ sôbre a vida sexual do homem, nos Estados Unidos, foi a existência de uma estreita relação entre o grau de instrução e a promiscuidade sexual. Assim, quanto maior o número de anos de escola cursado por um indivíduo, menos promíscuo é êle, segundo as conclusões do Prof. Kinsey e seus colaboradores.

Ora, estando a sífilis e outras doenças venéreas na dependência direta do grau de promiscuidade sexual do grupo social, pode-se prever, de antemão. que 
a taxa de sífilis entre os estudantes, principalmente entre os universitários, deve ser muito baixa. Isso, sem levar em conta outros fatôres importantes, tais como o grupo de idade e o padrão de vida.

De fato, o resultado de um inquérito sorológico para o diagnóstico da sífilis, realizado por Bowdoin e colaboradores em Savannah (EE. UU.), em 1945, entre mais de 70.000 pessoas da população da cidade, mostrou que os estudantes apresentavam a taxa mais baixa. Foram computados apenas aquêles de idade superior a 15 anos, de ambos os $\operatorname{sexos}{ }^{77}$.

Também na Venezuela, em um inquérito sorológico realizado entre várias camadas da população, os estudantes apresentaram a menor taxa. Entre 3.508 estudantes foi observado $3,7 \%$ de positividade, quando a taxa dos operários foi de $17,7 \%{ }^{78}$.

Smillie ${ }^{79}$ menciona como sendo de 1 por 1.000 o coeficiente de positividade das reações para o diagnóstico da sífilis, entre os estudantes das universidades dos Estados Unidos.

Tumbleson ${ }^{80}$ apresenta o resultado do exame de sangue feito em 78.388 estudantes de universidades norte-americanas, tendo sido encontrada uma taxa de positividade de 1,99 por 1.000. Entre universitários negros a taxa foi de 26,8 por 1.000 .

$\mathrm{Na}$ Finlândia, em um inquérito realizado entre 10.445 dos 12.511 estudantes de universidade, em 1946 e 1947, Kilpiö e colaboradores ${ }^{81}$ encontraram 11 reações de Kahn persistentemente positivas. Ao exame clínico verificou-se que 2 estudantes já estavam em tratamento, e 9 casos eram de sífilis latente.

Wenger e Usilton ${ }^{82}$, estudando 10.000 portadores de doenças venéreas, nos Estados Unidos, observaram que:

$6 \%$ nunca havia frequentado escola;

$50 \%$ havia frequentado a escola primária durante 1 ou mais anos;

$37 \%$ havia frequentado escola secundária apenas durante algum tempo; menos de $1 \%$ possuia nível educacional acima da escola secundária.

Concluem os autores que, quanto mais educado é o indivíduo, mais êle cuida da profilaxia, e mais depressa procura tratamento, do que um indivíduo com menor grau de instrução.

Entre nós, Paula Souza ${ }^{83}$ encontrou 2,59\% de reações positivas entre os estudantes das escolas superiores matriculados no Instituto de Higiene.

Mendes de Castro ${ }^{84}$, analisando as fichas de 4.318 escolares matriculados na Diretoria do Serviço de Saúde Escolar, durante os anos de 1943 a 1047, encontrou 51 casos de sífilis, o que dá uma percentagem de 1,18 de sífilis congênita, pois se tratavam de menores de 12 anos.

Mammana e Hidal ${ }^{85}$, através de reações sorológicas realizadas entre alguns grupos de estudantes da capital paulista em 1950-51, encontraram: $2,50 \%$ de reações positivas entre 360 estudantes do curso secundário; $3,47 \%$ em 230 estudantes do curso profissional; $1.38 \%$ entre 361 colegiais do sexo feminino, de internato, cujas idades iam de 12 a 29 anos. 
Buzzoni ${ }^{86}$, examinando as fichas de cêrca de 1.000 menores internados no Educandário D. Duarte, durante o período 1945-1951, encontrou 1,3\% de reações de Wassermann e Kahn positivas. Deve-se esclarecer que, naquele educandário, cêrca de $60 \%$ dos internados são pardos ou pretos.

Em 1949, retomamos o trabalho de Paula Souza e, através das fichas de exame médico a que os universitários são submetidos na Faculdade de Higiene e Saúde Pública, por ocasião do seu ingresso na Universidade de São Paulo, verificamos que, no período compreendido entre 1945 e 1948, dos 748 estudantes do sexo masculino examinados, $4,3 \%$ apresentava passado sifilítico ${ }^{87}$.

A taxa por nós observada não foi baixa, comparando-se com outros estudos. Devemos esclarecer, porém, que não consideramos apenas o resultado das reações sorológicas, mas também o passado venéreo. Alguns estudantes apresentavam sorologia negativa, porém acusavam a sífilis no seu passado venéreo.

Durante o ano de 1950 foram submetidos a exame de sangue para o diagnóstico da sífilis, na Faculdade de Higiene e Saúde Pública, 1.164 estudantes da Universidade de São Paulo. Foram verificadas 26 reações de Wassermann e Kahn positivas, o que significa uma taxa de $2,2 \%$.

Se for levado em conta, que entre as reações positivas figuram alguns universitários em tratamento, com repetição de exames, podemos concluir que o coeficiente real é ainda mais baixo.

Em outra observação nossa, resultante da revisão das fichas de 1.454 universitários do sexo masculino, entre 18 e 30 anos de idade, inscritos na Faculdade de Higiene e Saúde Pública durante o período 1945-1950, encontramos $227 \mathrm{com}$ passado venéreo, o que significa uma porcentagem de 15,6.

A taxa encontrada diz respeito ao passado venéreo do estudante, e não sig. nifica, absolutamente, presença de doença venérea por ocasião do exame.

Fazendo a distribuição dos universitários incluidos em nossa observação, em relação às escolas onde êles estudavam, verificamos o seguinte:

Faculdades

Fac. de Direito

E. S. Agríc. "Luiz de Queiroz" .....

Fac. de C. Econônicas ..............

Fac, de Med. Veterinária ..........

Fac. de Filosofia ..................

Fac. de Odontologia ................

Fac. de Arquitetura e Urb. ..........

Fac. de Farmácia .................

Fac. de Medicina $\ldots \ldots \ldots \ldots \ldots \ldots$.

Esc. Politécnica

Examinados
171
32
60
73
88
174
15
51
324
466

$\begin{array}{cc}\begin{array}{c}\text { Com passado } \\ \text { venereo }\end{array} & \% \\ 77 & 45,6 \\ 14 & 43,7 \\ 14 & 23,3 \\ 16 & 21,9 \\ 16 & 18,1 \\ 25 & 14,3 \\ 2 & 13,3 \\ 6 & 11,7 \\ 30 & 9,2 \\ 27 & 5,7\end{array}$

A gonorréia foi a moléstia venérea mais frequente. Cêrca de $65 \%$ dos rapazes a mencionavam no seu passado venéreo. A sífilis vinha logo em segundo lugar. Foram verificados 58 casos de sífilis, o que dá para o total dos universitários examinados uma taxa de $3,9 \%$. 
Os coeficientes elevadíssimos de venéreas referentes às escolas de Direito e Agrícola "Luiz de Queiroz" podem ser interpretados da seguinte maneira: os estudantes dessas duas escolas não comparecem em grande número para os exames a que estão sujeitos na Faculdade de Higiene; uns porque são desinteressados, e outros porque vivem em cidade distante da capital. Os alunos dessas escolas que procuram aquela Faculdade é porque suspeitam do seu estado de saúde. Há, então, uma seleção da amostra das referidas escolas. O resul. tado encontrado não deve representar a situação verdadeira.

O contrário sucede em relação às escolas de Medicina e Politécnica. Todos, ou quase todos os alunos dessas escolas são submetidos aos exames médicos e de laboratório da Faculdade de Higiene, e a taxa encontrada entre êles deve se aproximar bastante da realidade.

\section{A SIFILIS ENTRE OS MILITARES}

A importância da sífilis nos exércitos foi notada desde a epidemia do século XV, no exército de Carlos VIII. A maioria dos grandes exércitos e marinhas do mundo começou a coletar dados de morbidade desde 1865-1880 até os nossos dias.

Moore ${ }^{88}$ acha que a observação dos fatos permite uma estimativa grosseira, em tempo de paz ou de guerra, da frequência da sífilis na população civil através dos grupos militares. A incidência das infecções recentes entre os militares forneceria, aproximadamente, o índice de prevalência e, talvez mesmo, da incidência, na população civil onde o grupo militar está situado.

Informações referentes aos 9 maiores exércitos da Europa e mais aquelas que dizem respeito ao exército norte-americano permitem evidenciar que, durante o período 1865-1910 houve um declínio espontâneo na incidência de infecções recentes de sífilis nos meios militares ${ }^{89}$.

Não constitui novidade para ninguém a afirmação de que a incidência da sifilis aumenta durante as guerras, na população militar e civil. Isto foi bem demonstrado durante a $1^{*}$ Guerra Mundial nos exércitos francês e alemão. A curva de incidência da sífilis no exército norte-americano mostra elevações nos períodos referentes à Guerra Civil (1861-1871), 1 a e $2^{\text {a }}$ Guerra Mundial (1939. 1949). Os picos de tais elevações estão situados em períodos que correspondem às guerras, ou imediatamente após as mesmas, porém caem dentro de 4 anos ao nível anterior ou até mais baixo que antes da guerra ${ }^{90}$.

As taxas de incidência ou prevalência da sífilis entre os exércitos dos diferentes países são as mais variadas possíveis.

Em 1941, os dados referentes ao primeiro milhão de homens convocados nos Estados Unidos mostrava uma taxa de sorologia positiva em 4,5\%.

Entre 1.061.843 indivíduos examinados entre novembro de 1940 a abril de 1941, 47.552 foram recusados pelo Selective Service, sendo que a taxa de sífilis encontrada para o branco foi de $1,8 \%$ e para o preto $24.70 \%{ }^{91}$.

No exército finlandês a taxa de sífilis primária e secundária caiu de 27,8 por $1.000 \mathrm{em} 1919$ para 2,8 por $1.000 \mathrm{em}$ 1947, com flutuações por ocasião das guerras ${ }^{92}$. 
Durante o período 1934-1937 o exército francês metropolitano e colonial apresentava os seguintes índices de sífilis:

$\begin{array}{lrc}\text { Ano } & \text { Exército metropolitano } & \text { Exército colonial } \\ 1934 & 17,44 \text { por } 1.000 & 21,06 \text { por } 1.000 \\ 1935 & 10,62 \text { por } 1.000 & 14,87 \text { por } 1.000 \\ 1936 & 10,85 \text { por } 1.000 & 13,15 \text { por } 1.000 \\ 1937 & 10,16 \text { por } 1.000 & 18,36 \text { por } 1.000\end{array}$

As doenças venéreas constituem um sério problema na marinha norte-americana. Em 1945 custou ao govêrno mais de seis milhões e meio de dólares a hospitalização e a manutenção dos portadores de venéreas, sem levar em conta os gastos com as pensões dos inválidos.

Foram registrados 28 casos de venéreas em cada 1.000 homens da marinha norte-americana em 1950.

Em países, como o nosso, onde a sífilis não é moléstia de notificação obrigatório e nem existem outras medidas que facilitem os dados sôbre a incidência ou prevalência da moléstia na população, os estudos realizados nas fôrças armadas seriam valiosos e os mais seguros de que o sanitarista pudesse lançar mão.

Infelizmente, o exército brasileiro não é o sifilômetro da nação, e isto se deve, principalmente, à não existência de um órgão destinado a controlar as doenças venéreas entre os militares. Tal como sucede na população civil. há vários serviços trabalhando independentemente, não há padronização de técnicas de diagnóstico, de laboratório ou de tratamento. Além disso, faltam técnicos sôbre o assunto que possam orientar os outros médicos e traçar planos de contrôle de acôrdo com as nossas necessidades e possibilidades.

Ao que parece, no entanto, no Brasil a sífilis e outras doenças venéreas são das doenças mais frequentes entre os militares.

Segundo um "Mapa estatístico-patológico das praças entradas nos Hospitais e Enfermarias Militares do Município Neutro e Províncias do Império, durante o ano de $1872 "{ }^{93}$, apresentado pelo cirurgião-mor do Exército, Dr. José Ribeiro de Souza Fontes, as moléstias que predominaram estavam assim distribuidas: 1\%) A sífilis, representada por 2.328 doentes; 2\%) as moléstias do aparelho da respiração, com 1.779 doentes; $3^{\circ}$ ) as do aparelho da digestáo, com 1.736 doentes etc. Infelizmente, não se conhece o efetivo da tropa, a fim de se poder estabelecer a proporção, mas, de qualquer maneira, fica evidenciada a grande frequência da sífilis entre os soldados naquela época.

Em 1929, o coronel médico Dr. Artur Lôbo da Silva, apresentava uma memória ao $1^{\circ}$. Congresso Brasileiro de Eugenia, com os primeiros dados estatísticos sôbre os males venéreos no Exército. Baseava-se aquêle autor em estatísticas de doentes baixados ao Hospital Central do Exército, no período 1909. 1920. Mais da quarta parte dos doentes internados, isto é, 283 por 1.000, era devida à doença venérea.

Segundo o mesmo autor, entre os anos de 1919 e 1928, o efetivo médio do Exército nacional foi de 320.769 homens, tendo havido, nesse tempo, 69.170 baixas aos estabelecimentos militares de Saúde, por motivo de doenças vené- 
reas, o que significa que a quinta parte do efetivo do Exército baixou ao hospital por essa razão.

Em 1932, os trens chegados ao Rio, provenientes do Vale do Paraíba, traziam muito mais portadores de doenças venéreas do que feridos, havendo mes. mo necessidade de, pela primeira vez na história do Serviço de Saúde do Exército, se recorrer à hospitalização complementar, sendo instalado, de urgência, o Hospital Complementar de Exército Gaffré-Guinle ${ }^{94}$.

O capitão Dr. João Baptista Pereira Bicudo ${ }^{95}$ apresenta o seguinte quadro sôbre a frequência das doenças venéreas no Exército, no período compreendido entre 1935 e 1944:

$\begin{array}{ccc}\text { Ano } & N^{\circ} \text { de casos } & \begin{array}{r}\text { Casos por } 1.000 \\ \text { homens de efetivo }\end{array} \\ 1935 & 1.954 & 126,66 \\ 1936 & 1.177 & 88,66 \\ 1937 & 1.510 & 100,66 \\ 1938 & 1.784 & 118,92 \\ 1939 & 1.668 & 111,20 \\ 1940 & 2.008 & 133,86 \\ 1941 & 1.757 & 117,13 \\ 1942 & 1.638 & 109,20 \\ 1943 & 1.813 & 120,86 \\ 1944 & 3.033 & 101,10\end{array}$

Comparando os resultados dos últimos anos com os dados encontrados, no mesmo período, no Exército norte-americano, verificamos a seguinte percentagem para as doenças venéreas, para aquêle Exército:

$\begin{array}{cc}\text { Ano } & \text { No de casos por } 1.000 \\ 1941 & 40,5 \\ 1942 & 39,3 \\ 1943 & 26,3 \\ 1944 & 33,2 \\ 1945 & 44,0\end{array}$

Vilas Boas e colaboradores ${ }^{96}$ estudando o problema da incidência da sífilis no Exército, apresentam um quadro sôbre a frequência da moléstia entre os soldados hospitalizados no Hospital Central do Exército, de 1928 a 1939:

\begin{tabular}{|c|c|c|c|c|c|}
\hline Ano & & $s$ de sifilis & Ano & & Casos de sifilis \\
\hline 1928 & $\ldots \ldots \ldots \ldots$ & $2,05 \%$ & 19834 & $\ldots \ldots \ldots \ldots$ & $3,1 \% \%$ \\
\hline 1929 & $\ldots \ldots \ldots \ldots \ldots$ & $3,54 \%$ & 1935 & $\ldots \ldots \ldots \ldots$ & $2,05 \%$ \\
\hline 1930 & $\ldots \ldots \ldots \ldots \ldots$ & $3,47 \%$ & 1936 & $\ldots \ldots \ldots \ldots \ldots$ & $3,06 \%$ \\
\hline 1931 & $\ldots \ldots \ldots \ldots \ldots$ & $3,00 \%$ & 1937 & & $4,62 \%$ \\
\hline 1932 & $\ldots \ldots \ldots \ldots \ldots$ & $2,86 \%$ & 1938 & $\ldots \ldots \ldots \ldots \ldots$ & $1,46 \%$ \\
\hline 1933 & $\ldots \ldots \ldots \ldots$ & $2,80 \%$ & 1939 & $\ldots \ldots \ldots \ldots$ & $2,52 \%$ \\
\hline
\end{tabular}

Erasmo Lima ${ }^{97}$ referindo-se à incidência da sífilis na Marinha diz que "a média dos efetivos da Marinha foi então, durante o quinquênio (1935-1939), de 20.278 homens, sôbre a qual verificou-se uma média de 794 casos de sífilis, ou seja a elevada cifra de 39 casos por 1.000". 
Não concordamos com o autor em que a cifra de 39 casos por $1.000(3,9 \%)$ seja elevada, em se tratando de marinheiros, isto é, indivíduos jovens em sua maioria, e afastados do lar.

Aliás, quase todos os dados apresentados sôbre a frequência da sífilis entre os militares brasileiros são falhos e não podem contribuir para um estudo da incidência ou prevalência dessa moléstia no meio militar. Não há uniformidade na colheita dos dados, não há um contrôle seguro sôbre as doenças venéreas em todos os agrupamentos militares, e grande parte de infecções não é notificada.

Um fator de êrro reside nas amostras apresentadas; quase tôdas dizem respeito aos soldados baixados ao hospital, e as readmissões para tratamento da mesma moléstia costumam ser contadas corso casos novos em muitas estatísticas fornecidas.

Indiscutivelmente, um dos maiores trabalhos realizados no Exército brasileiro para a pesquisa de sífilis, foi o inquérito sorológico realizado entre junho de 1944 e abril de 1945, para a seleção da Fôrça Expedicionária Brasileira.

Foram realizadas reações de Kahn em 36.694 homens, tendo Pedrosa ${ }^{98}$ feito 16.000 reações e Almeida ${ }^{99}$ 20.694. O primeiro autor encontrou $12,60 \%$ de positividade, e o segundo, $15,15 \%$, o que Pedrosa atribui à inclusão na amos. tra, de maior número de jovens provenientes do norte do país.

Excetuando-se do estudo os capelães, enfermeiras e outros civis, o quadro referente aos 36.536 militares examinados é o seguinte:

\begin{tabular}{|c|c|c|c|}
\hline & Examinados & Positivos & $\%$ \\
\hline$\ldots \ldots \ldots \ldots \ldots \ldots \ldots \ldots \ldots \ldots \ldots \ldots \ldots \ldots$ & 1.797 & 105 & 5,84 \\
\hline Sub-tenentes e sargentos & 3.483 & 572 & 16,42 \\
\hline 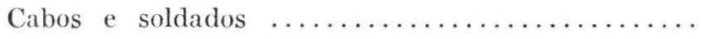 & 31.256 & 4. 466 & 14,28 \\
\hline 'Total & 36.536 & 5.143 & 15,44 \\
\hline
\end{tabular}

Infelizmente, ao que parece, não foram anotados os resultados em relação ao grupo de idade e à raça. Poderíamos, então, conhecer através de um trabalho de vulto como êsse, a diferença da taxa de sífilis para o branco, para o pardo e para o preto. A experiência do Exército norte-americano mostra a grande desproporção entre a incidência da sífilis no soldado branco e no preto, e nossas observações entre os operários de São Paulo, confirmam essa particularidade entre as duas raças, também entre nós.

Quanto à idade, talvez ficasse explicado porque os sub-tenentes e sargentos apresentaram taxa mais elevada. Ésses militares têm padrão de vida pouco diferente do soldado, porém são mais idosos.

No meio militar de São Paulo os dados estatísticos não são mais abundantes e nem mais seguros.

Ruy Faria ${ }^{100}$ apresenta algumas informações a respeito dos soldados baixados ao Hospital Militar de São Paulo: 


$\begin{array}{lrc}\text { Ano } & \text { Soldados baixados ao hospital Com } & R W . \text { positiva } \\ 1941 & 3.595 & 2,9 \% \\ 1942 & 3.771 & 3,2 \% \\ 1943 & 4.479 & 2,7 \%\end{array}$

Esses dados são falhos porque nem todo soldado baixado ao hospital faz exame de sangue. O mesmo autor, revendo as fichas do laboratório do Hospital, num período de 18 meses encontrou $52,30 \%$ de resultados positivos, enquanto que o número de casos de sífilis nos mapas nosográficos, nesse período, era da ordem de $15 \%$.

Ainda nesse período, baixaram ao Hospital 6.715 soldados, dos quais apenas $21 \%$ foram submetidos ao exame sorológico, que resultou positivo em $10,20 \%$.

Como se pode perceber, os resultados são os mais disparatados possíveis, não merecendo crédito nenhum dêles. As principais causas de êrro residem na ausência de exame de sangue de rotina entre os soldados que baixam ao Hospital, e nos resultados globais do laboratório, onde o mesmo paciente pode ser contado inúmeras vezes.

Nós, autorizados pelo Comandante Geral da Fôrça Pública de São Paulo, Tenente-Coronel E. Jesus Zerbini, revimos o fichário do laboratório do Hospital Militar daquela entidade, durante o período compreendido entre 13 de março de 1950 a 12 de março de 1951. Foram realizadas, nesse período, reações de Kahn em 1.916 militares, tendo havido 332 reações positivas, ou seja $17,3^{\circ}$ '

Em virtude das taxas obtidas através de relatórios de hospitais e ambulatórios nåo exprimirem a realidade da situação da sífilis entre os soldados, já se iniciou, entre nós, a prática do inquérito sorológico nos quarteis.

Em 1937, Vieira Macedo ${ }^{101}$, fazendo um inquérito sorológico entre 1.817 convocados do Exército, sediados na capital de São Paulo, encontrou 8.39\% de reações positivas. Entre soldados da Base Aérea de Cumbica a taxa de positividade foi de $8,87 \%$.

O mesmo autor. em estudos realizados em 1950 e $1951^{102}$. encontrou $3.35 \%$ de reações positivas em 536 soldados do 4\% Regimento de Infantaria; 2,0\% entre 342 homens da Escola de Cadetes; 2,8\% entre 208 soldados do 2\% Esquadrão de Reconhecimento Mecanizados; todos sediados na capital paulista.

No mesmo período, Mammana e Hidal ${ }^{103}$, examinando 430 soldados e convocados do Exército, encontraram $3.25 \%$ de reações positivas.

Nós, em setembro de 1951, examinamos 257 homens do Batalhão de Guardas da Fôrça Pública do Estado, e 165 do Regimento de Cavalaria, da mesma organização militar, todos sediados na capital paulista.

O sangue foi colhido no próprio quartel, e os exames realizados no Departamento de Bacteriologia da Faculdade de Higiene e Saúde Pública. Foram efetuadas reações de Wassermann, Kahn e V.D.R.L. em tôdas as amostras de sôro sanguíneo.

No Batalhão de Guardas foram encontradas 21 reaçóes positivas, o que dá um coeficiente de $8,17 \%$; no Regimento de Cavalaria as reações positivas foram em número de 29 , ou seja $17,5 \%$. 
Batalhão de: Guardas

I

\begin{tabular}{lcc}
\multicolumn{1}{r}{ Côr } & Examinados & $R W$. positiva \\
Brancos & 223 & 20 \\
Pretos & 12 & 0 \\
Pardos & 22 & 1
\end{tabular}

II

E. civil

Solteiros

Casados

$\begin{array}{cc}\text { Examinados } & \text { RW. positiza } \\ 207 & 17 \\ 50 & 4\end{array}$

III

Graduação

Sargentos

Cabos

Soldados

Examinados RW. positive

17

6
234

6
2

13

IV

Idade
$16-20$
$21-25$
$26-30$
$31-35$
$36-40$
$41-45$
$46-50$

Examinados RW. positiva

42

134

48

16

8

5
Regimento ne Cavalaria

I

$\quad$ Côr
Brancos
Pretos
Pardos

Examinados $R W$. positiva

138

16

24

Pardos

II

E. civil

Solteiros

Casados

Examinados WR. positiza

125

24
5

I I I

Graduação

Examinados RW. positiva

Aspirantes

Sargentos

Cabos

Soldados

Não espec.

$\begin{array}{rr}2 & 2 \\ 15 & 4 \\ 16 & 1 \\ 129 & 22 \\ 3 & 0\end{array}$

IV

Idade
$16-20$
$21-25$
$26-30$
$31-35$
$36-40$
$41-45$
$46-50$

Eraminados RW. positiza

$\begin{array}{cr}16 & 2 \\ 78 & 13 \\ 29 & 5 \\ 13 & 5 \\ 11 & 2 \\ 10 & 1 \\ 8 & 1\end{array}$

Infelizmente, o número de indivíduos examinados não é suficientemente grande para que se possa tirar conclusóes mais precisas a respeito de vários fatôres que parecem estar relacionados à taxa de incidência da sífilis entre êsses militares.

Notamos, porém, desde logo, a diferença de coeficiente encontrado para o Batalhão de Guardas e a Cavalaria. Segundo informações obtidas entre os superiores, os cavalarianos são tidos como elementos dos mais "boêmios" entre os soldados da Fôrça Pública; daqueles que não se dão ao trabalho de selecionar o parceiro amoroso. Era esperado, de antemão, que o resultado do exame de sangue nesse grupo fôsse mais elevado. Não acreditávamos, porém, que a diferença fôsse tão grande.

Um outro fato curioso reside nas taxas de positividade referentes ao branco e ao preto, as quais são aproximadamente iguais.

Tal achado vem reforçar a afirmação de que a incidência da sífilis está relacionada, principalmente, a fatôres econômicos e sociais. Neste caso, quando soldados brancos e pretos possuem as mesmas características de instrução, educação, e percebem os mesmos salários, não há entre os mesmos, pràticamente, grande variação da taxa de incidência de venéreas. Estamos prosseguin- 


\begin{tabular}{|c|c|c|c|}
\hline II - Estado civil & Examinados & $R W$. positiva & $\%$ \\
\hline$\ldots \ldots \ldots \ldots \ldots \ldots \ldots$ & 560 & 110 & 19,6 \\
\hline Casados $\quad \ldots \ldots \ldots \ldots \ldots \ldots$ & 465 & 219 & 47,0 \\
\hline Viúvos $\quad \ldots \ldots \ldots \ldots \ldots \ldots \ldots \ldots \ldots$ & 54 & 22 & 40,7 \\
\hline Amasiados $\ldots \ldots \ldots \ldots \ldots \ldots$ & 4 & 0 & \\
\hline Não declarados $\ldots \ldots \ldots \ldots \ldots$ & 38 & 8 & \\
\hline & 1. 121 & 359 & \\
\hline III - Nacionalidade & Examinados & $R W$. positiva & $\%$ \\
\hline Brasileiros $\quad \ldots \ldots \ldots \ldots \ldots \ldots$ & 1.034 & 341 & 32,9 \\
\hline Estrangeiros $\quad \ldots \ldots \ldots \ldots \ldots \ldots$ & 60 & 14 & 23,3 \\
\hline Não declarados . . . . . . . . . . . & 27 & 4 & \\
\hline & 1.121 & 359 & \\
\hline
\end{tabular}

$90 \%$ dos prisioneiros com sorologia positiva estava situado entre o grupo de idade compreendido entre 20 e 40 anos; e mais da metade era natural de São Paulo.

Verificamos em nossas observações que o fator raça parece não ter grande infiuência. Deixamos de dar grande importância à taxa encontrada para os sentenciados de raça amarela porque a amostra examinada é muito pequena.

Quando se verifica, comumente, a grande desproporção entre as taxas de incidência ou prevalência da sífilis entre indivíduos brancos e pretos, é de se notar, neste grupo examinado, a sua tendência à aproximação.

Não temos informações sôbre o grau de instrução dos dois grupos que estamos analisando, nem de que camada social êles provêm. Sabemos apenas que estão, mais ou menos, compreendidos entre os mesmos limites de idade.

A nossa impressão é a de que todos êsses indivíduos, ou pelo menos a grande maioria, provenha do mesmo ambiente social, sofrendo a mesma nivelação imposta pelo crime. Isto significa que indivíduos da raça preta e da raça branca quando em ambientes semelhantes apresentam o mesmo grau de promiscuidade sexual e, consequentemente, a mesma taxa de doenças venéreas.

Augusto Silva e Silva Teles ${ }^{119}$ estudaram, em 1940, 5.500 casos de sentenciados matriculados desde 1920 a 31 de dezembro de 1939, na mesma penitenciária do Estado, e encontraram $53,44 \%$ de reações positivas.

Analisando mais minuciosamente êsses casos, verificaram aquêles autores que:

Entre 780 pretos a taxa de positividade foi de $58,59 \%$

Entre 1.110 mulatos a taxa de positividade foi de $56,58 \%$

Entre 2.706 brancos a taxa de positividade foi de $52,00 \%$

Podemos verificar que os dados encontrados, embora mais elevados, muito se assemelham àqueles por nós observados.

Em relação à nacionalidade, também são êles concordantes:

Em 4.596 brasileiros havia $54,2 \%$ de reações positivas Em 904 estrangeiros havia $49,45 \%$ de reações positivas 


\section{O PROBLEMA DA PROSTITUICÃO}

Há fortes razões para se acreditar que a promiscuidade sexual seja tão vetha quanto a raça humana.

Os antropologistas nos afirmam que, antes do desenvolvimento da família, a promiscuidade era a regra.

A monogania teria se desenvolvido posteriormente. como resultado de fatôres de ordem moral e econômica, porém tais fatôres jamais conseguiram afastar completamente o homem de suas tendências para a promiscuidade.

A promiscuidade sexual começa a ser encarada com grande interêsse pelos venereologislas modernos, pois nela reside tôda a razão de ser da disseminação das doenças venéreas. Um dos seus aspectos mais sérios, sol, o ponto de vista social e sanitário é, sem dúvida nenhuma, a prostituição.

A prostituição é conhecida desde os tempos bíblicos. Assumindo um caráter religioso é encontrada em vários povos. Herodoto conta que tôda a muiher da Babilonia era obrigada a se prostituir, pelo menos uma vez, em homenagem à densa Afrodite.

Constantino aboliu, no seu tempo, o costume das mulheres dedicadas ao templo entregarem-se à prostituição.

A prostituição estava tão generalizada na antig̨a Grécia que Solon resolveu criar o hordel público, "um estahelecimento secular para um fim secular, com o fito de salvaguardar a populacão e de aumentar o erário público" 1o. Seria essa, segundo alguns autores, a origem da regulamentação do meretrício.

Para Vedder ${ }^{121}$ a prostituição seria resultanite de um conflito entre as necessidades imperiosas do instinto sexual e as limitações do meio ambiente.

A reprodução é uma possibilidade fisiológica que tem lugar logo após a primeira década da vida do indivíduo e, se o casamento fôsse orientado exclusivamente pelas leis fisiológicas, deveria ter lugar, normalmente, antes dos 18 anos de idade.

Acontece, no entanto, que os impulsos fisiológicos não estão subordinaros às condições ambientes, principalmente no que diz respeito às regras do comportamento social. Isso gera um conflito que traz como consequência a prostituição.

Vedder combate as afirmações frequentes de que as mulheres são orientadas para a prostituição devido à sua condição de inferioridade econômica. Para êle, o principal fator da existência da prostituição seria a procura por porte do homem.

Richmond ${ }^{122}$ partilha das mesmas idéias. Tendo o homem um apetite sexual que começa cedo e só se casando tarde por motivo de ordem econômica, é. nesse ínterim, o fomentador da prostituição em tôdas as suas formas.

Seria o fator econômico, portanto, o maior responsável pela prostituição, mas relacionado ao homem, principalmente.

Os estudos realizados pelos diversos pesquisadores não têm sido concordes quanto ao fator principal que leva a mulher à prostituição. Psiquiatras e p£icologistas têm tentado elucidar, sob o ponto de vista de suas especialidades, a razão de ser da mulher prostituta. 
Já em 1936 a Secção Social da Liga das Nações ${ }^{123}$ havia promovido um questionário, o qual foi enviado a diversos países e associações particulares, a fim de serem prestadas informações sôbre prostitutas naturais do país. Foram recebidas respostas de 20 diferentes países, perfazendo um total de $2.659 \mathrm{mu}$ lheres entrevistadas.

Os psiquiatras encarregados de estudar 50 mulheres nos Estados Unidos encontraram 17 com inteligência superior ou normal, e 33 variando entre a estupidez e a imbecilidade.

O relatório das prostitutas de Copenhague foi feito pelo Dr. Tange Kempe ${ }^{121}$ e abrangia 530 mulheres. Esse investigador especializado observou as mulheres e encontrou apenas $29,4 \%$ com inteligência que podia ser considerada normal.

Na Rumânia, Uruguai, Índia e Noruega a maioria das mulheres foi classificada como mentalmente normal. No entanto, como em certos países os questionários não foram preenchidos por psiquiatras ou indivíduos especializados no assunto, o critério de normalidade ou anormalidade mental não pôde ser levado em grande conta.

Estudos psiquiátricos levados a cabo em São Francisco, Califórnia, entre 620 indivíduos (365 mulheres e 255 homens), oriundos de clínicas de doenças venéreas, entre 1943 e $1947^{125}$, trabalhos êsses que tinham por finalidade estudar o problema da promiscuidade sexual, revelaram o seguinte:

1) A maioria dos indivíduos acusava uma influência pouco satisfatória do meio familiar. Êles provinham, quase sempre, de lares desfeitos.

2) Não foi demonstrada nenhuma evidência de que os indivíduos sexualmente promíscuos fôssem possuidores de maior sensualidade do que a média geral. Foram encontradas, mesmo, algumas mulheres sexualmente frias.

3) Um meio ambiente desfavorável, condições más de vida, ausência de liâmes de amizade, e amigos casuais, foram fatôres considerados como tendo contribuido fortemente para um comportamento sexual promíscuo, mas nem por isso podiam ser responsabilizados como a sua causa primária.

A conclusão dêsse estudo foi de que a promiscuidade sexual era o resultado de um desajustamento da personalidade, a qual apresentava conflitos, deficiências ou outros distúrbios.

\section{A prostituição e as doenças venéreas}

Considerando-se que o contágio das doenças venéreas se faz, principalmente, pelo congresso sexual, a promiscuidade nas relações sexuais deve ser considerada, por conseguinte, como o principal fator de propagação de tais doenças. Ora, a prostituição é o grau mais elevado que pode atingir a promiscuidade sexual. Não é para admirar, portanto, que seja ela o grande reservatório dos germes das doenças venéreas, e o seu maior foco de disseminação. 
Desde a Idade Média, quando os marinheiros e mercadores começaram a correr o mundo, as casas de prostituição existiram em todos os portos da Ásia, espalhando-se depois para o interior dos países.

Na Europa, desde a queda do Império Romano até o fim do século XVI, as Cruzadas, a existência de exércitos mercenários, os viajantes, marinheiros e mercadores mantiveram a procura das relações sexuais comercializadas, e a existência dos bordéis foi incorporada à estrutura social de inúmeras cidades.

A relação entre as prostitutas que acompanhavam os exércitos e as doenças venéreas ficou logo estabelecida. Se dermos crédito ao relatório médico do cirurgião-mor do Duque de Alba, durante a guerra entre espanhóis e portuguêses, no século XVI, as doenças venéreas se tornaram um problema tão grave que êle e seus assistentes tiveram que amputar 5.000 pênis ${ }^{126}$.

No fim do século XIX, Fournier ${ }^{127}$ observou que $70 \%$ dos civis sifilíticos tratados em Paris tinha adquirido sua infecção de prostitutas registradas.

Em 1908, estudos feitos na Rússia ${ }^{128}$ mostraram que, em São Petersburgo, de 3.191 portadores de doenças venéreas, $90,8 \%$ haviam se infectado com prostitutas profissionais.

Stokes ${ }^{129}$ menciona como sendo de 40 a $60 \%$ os contágios dos homens das fôrças armadas norte-americanas na prostituição organizada.

Lentino ${ }^{130}$ cita um trabalho realizado em São Paulo, em 1921, onde $70 \%$ dos 1.975 portadores de doenças venéreas examinados na Liga de Combate à Sífilis, acusavam a zona de prostituição como fonte de contágio.

O mesmo autor cita um inquérito realizado em 1928 nos Centros de Saúde da Capital de São Paulo. Em 1.077 homens portadores de doenças venéreas $1.001(93 \%)$ haviam se contaminado na zona do meretrício.

Clarke ${ }^{131}$, estudando 835 homens portadores de cancro sifilítico, observou que mais de $3 / 4$ dos casos havia sido infectado com prostitutas. Os solteiros atribuiam à prostituição o seu contágio em $87 \%$ dos casos, e os casados em $58 \%$.

Em 136 mulheres portadoras de lesão primária sifilítica o mesmo autor encontrou $59 \%$ das casadas. como tendo adquirido a doença do marido e $54 \%$ das solteiras devido ao exercício da prostituição.

\section{A zona do meretrício em São Paulo}

Em São Paulo, a zona do meretrício está situada no bairro do Bom Retiro, um bairro comercial e residencial não muito distante da cidade. As casas de prostituição tomam completamente as ruas Itaboca, Aimorés, Carmo Cintra e parte da rua Ribeiro de Lima.

Constitui um espetáculo degradante o que oferece a capital do Estado mais progressista do Brasil, com uma zona de prostituição como não existe mais em nenhum centro civilizado.

Todo sanitarista sente profunda humilhação sempre que é forçado a mencionar a situação real de sua terra em congressos ou reuniões no exterior. Talvez seja êsse sentimento de vergonha que tenha impelido a uma resposta afirmativa o representante do Brasil que devia responder a um questionário da Federação Abolicionista Internacional, relativo às medidas empregadas pelos governos das diversas nações a fim de reprimir a prostituição e prevenir a explo- 
ração de suas vítimas. À pergunta: "São os bordéis proibidos?" o Brasil res. pondeu "Sim" 132 .

Na verdade, o espetáculo oferecido pela zona do meretrício de São Paulo é de impressionar o visitante mais afeito às manifestações de degradação social e moral do ser humano.

Durante os primeiros meses do ano de 1948 fizemos um inquérito sorológico para o diagnóstico da sífilis, entre as mulheres habitantes dêsse local.

Visitamos casa por casa, entrevistando, pessoalmente, cada mulher que podíamos encontrar na ocasião. Inquiríamos da dona da casa a respeito das mulheres ausentes, tomando nota de seus nomes e principais sinais de identificação. Mais tarde voltávamos à mesma casa e repetíamos o questionário, a fim de nos certificarmos da veracidade das informações.

Por êsse modo ficamos sabendo que existe na zona do meretrício de São Paulo uma população de mulheres que aí reside, temporária ou permanentemente, e outro grupo de mulheres, que só vem às casas durante algumas horas do dia ou da noite a fim de exercer a prostituição, residindo em outros pontos da cidade.

Visitamos cêrca de 150 casas, porém, em virtude de haver, às vezes, duas e mais casas transformadas em uma única pensão, registramos apenas 135 casas. O número de casas e mulheres examinadas foi o seguinte:

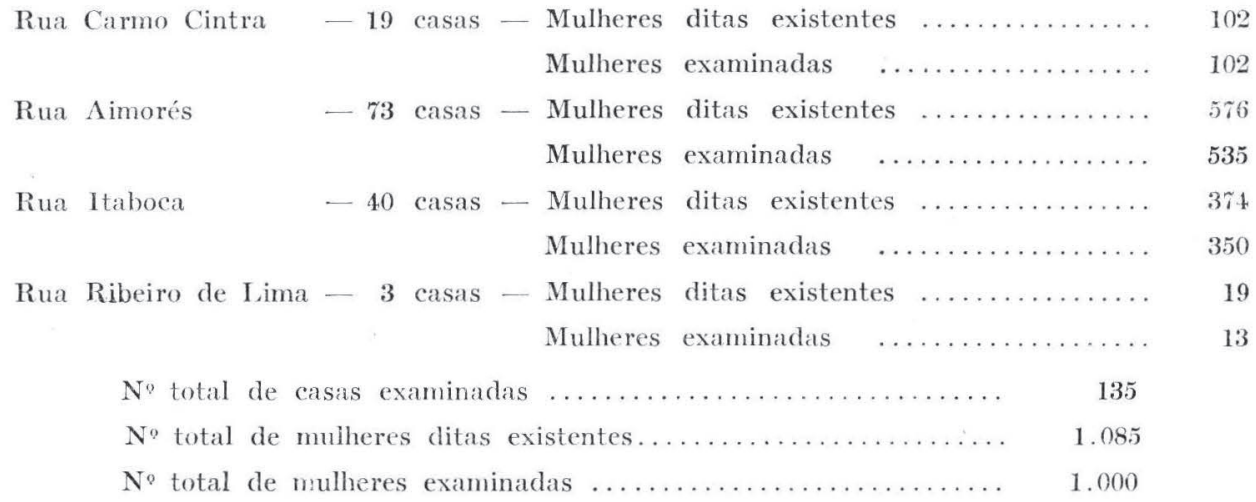

Apesar do número encontrado e das informações a respeito das outras mulheres que não estavam presentes na ocasião da nossa visita, nós calculamos como sendo de 10 a média de mulheres habitando cada casa; uma população de cêrca de 1.500 mulheres, portanto.

Dessas mulheres, examinamos 1.000, com a seguinte distribuição quanto à côr, nacionalidade e grupo de idade:

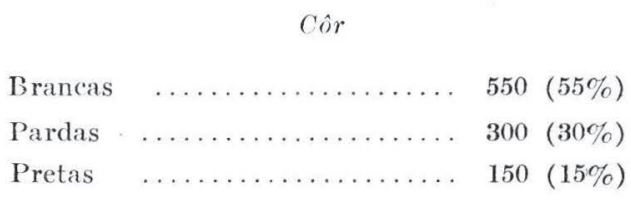




\begin{tabular}{|c|c|c|c|c|c|}
\hline \multicolumn{6}{|c|}{ Nacionalidade } \\
\hline Brasileiras & $\ldots \ldots \ldots \ldots \ldots$ & 922 & Paraguaias & $\ldots \ldots \ldots \ldots \ldots$ & 2 \\
\hline Francesas & $\ldots \ldots \ldots \ldots$ & 30 & Tcheca & $\ldots \ldots \ldots \ldots$ & 1 \\
\hline Polonesas & $\ldots \ldots \ldots \ldots$ & 25 & Lituana & $\ldots \ldots \ldots \ldots$ & \\
\hline Espanholas & $\ldots \ldots \ldots \ldots$ & 4 & Alemã $\quad$. & $\ldots \ldots \ldots \ldots \ldots$ & \\
\hline Uruguaias & $\ldots \ldots \ldots \ldots \ldots$ & 3 & Síria & $\ldots \ldots \ldots \ldots \ldots \ldots$ & \\
\hline Húngaras & $\ldots \ldots \ldots \ldots$ & 3 & Belga $\quad$. & $\ldots \ldots \ldots \ldots \ldots$ & 1 \\
\hline Rumenas & $\ldots \ldots \ldots \ldots \ldots$ & 2 & Iuguslava & $\ldots \ldots \ldots \ldots \ldots$ & 1 \\
\hline Russas & $\ldots \ldots \ldots \ldots$ & 2 & Japonêsa & $\ldots \ldots \ldots \ldots \ldots$ & \\
\hline
\end{tabular}

Idade

\begin{tabular}{|c|c|c|c|c|c|c|c|c|}
\hline De 16 a & 20 & anos & & 90 & De 36 & a 40 & anos & \\
\hline 21 & 25 & anos & $\ldots \ldots \ldots$ & 360 & De 41 & 45 & anos & \\
\hline 26 & 30 & anos & $\ldots \ldots \ldots$ & 275 & De 46 & 50 & anos & . \\
\hline 31 a & 35 & anos & $\ldots \ldots \ldots \ldots$ & 113 & De 51 & 55 & anos & \\
\hline
\end{tabular}

Como se pode ver, a maioria das mulheres $(82,3 \%)$ estava compreendida entre 21 e 35 anos de idade.

Já havíamos iniciado o nosso trabalho quando nos lembramos de indagar a respeito do analfabetismo entre as prostitutas. Entrevistamos 830 mulheres e encontramos $52,4 \%$ de analfabetas. Deve-se lembrar que a taxa de analfabetismo da mulher brasileira, segundo o censo de 1940, é da ordem de $60 \%$.

A prevalência da sifilis entre as prostitutas da zona do meretrício de São Paulo

Todos os sanitaristas estão de acôrdo que a taxa de infecção sifilítica entre as prostitutas deve ser a mais elevada possível, devido ao grande número de contactos a que a mesma se expõe.

Smillie ${ }^{79}$ apresenta como sendo de 30 a $70 \%$ a positividade da reação de Wassermann realizada em larga escala entre as prostitutas dos Estados Únidos.

No Pará, entre julho de 1921 e junho de 1922, foram examinadas 772 prostitutas, matriculadas num serviço especializado, e a percentagem de reaçóes positivas encontradas entre elas foi de $62,2^{133}$.

Em 6.491 prostitutas examinadas em Caracas, em 1943, foram descobertos $58,7 \%$ de exames sorológicos positivos ${ }^{78}$.

Em Guaiaquil, Equador, o resultado do exame sorológico para o diagnóstico da sífilis revelou $16 \%$ de reações positivas em mais de 20.000 pessoas, sendo que, para as prostitutas, a positividade foi de $60 \%{ }^{134}$.

Em 1938, o exame de 43.000 prostitutas no Japão revelou $8,3 \%$ de reações positivas para a sífilis, quando na população a prevalência dessa moléstia era, na mesma ocasião, de $0,2 \%{ }^{135}$.

Realizamos a coleta de amostras de sangue de 1.000 mulheres da zona do meretrício de São Paulo e as encaminhamos ao laboratório do Departamento de Bacteriologia da Faculdade de Higiene e Saúde Pública para exame. Foram praticadas as reações de Wassermann e Kahn em tôdas as amostras. Nos casos de reações duvidosas procurávamos colher novo material e repetir as reações. 
Encontramos 836 reações positivas, o que dá uma percentagem de 83,6.

Das 836 mulheres com reações positivas, 362 tinham menos de 4 anos di prostituição e, se acreditarmos que elas tenham adquirido a moléstia nesse pe ríodo, poderemos supor que $43,3 \%$ dos casos era, possivelmente, contagiante.

Não pudemos, infelizmente, examinar fisicamente cada mulher. Procuráva mos, no entanto, observar com a maior atenção possível qualquer sinal aparentı de sífilis entre elas. Por essa maneira, examinando algumas mulheres que no: pareceram suspeitas, encontramos 9 casos de franco secundarismo sifilítico. Es tamos certos de que um exame físico completo em tôdas as mulheres da zonc do meretrício iria revelar um número alarmante de casos contagiantes de sífilis

Durante os meses de agôsto e setembro de 1951 repetimos o inquérito so rológico entre as prostitutas da zona do meretrício do Bom Retiro ${ }^{136}$.

As amostras de sangue foram colhidas nas próprias casas de prostituiçãc e encaminhadas para o Instituto Adolfo Lutz, onde eram realizadas as reações de Wassermann, Kahn e V.D.R.L.

Foram examinadas 465 mulheres das ruas Carmo Cintra, Ribeiro de Lima e Aimorés, tendo sido verificadas 164 reações positivas, isto é, 35,3\%.

Distribuidas segundo a côr e nacionalidade, foram verificadas as seguintes taxas:

$\begin{array}{lccc}\text { Côr } & \text { Examinadas } & \text { Positivas } & \% \\ \text { Brancas } & 331 & 107 & 30,3 \\ \text { Pretas } & 30 & 13 & 43,4 \\ \text { Pardas } & 104 & 44 & 42,3 \\ \text { Nacionalidade } & \text { Examinadas } & \text { Positivas } & \% \\ \text { Brasileiras } & 434 & 159 & 36,6 \\ \text { Estrangeiras } & 31 & 5 & 16,1\end{array}$

Em relação à idade encontramos os seguintes resultados:

$\begin{array}{lccr}\text { Idade } & \text { Examinadas } & \text { Positizas } & \% \\ \text { Menos de } 20 & 15 & 1 & 6,6 \\ 20-24 & 163 & 64 & 39,2 \\ 25-29 & 149 & 55 & 36,9 \\ 30-34 & 73 & 25 & 34,2 \\ 35-39 & 2 \cdot 2 & 4 & 18,0 \\ 40-44 & 19 & 8 & 47,3 \\ 45-49 & 10 & 3 & 30,0 \\ 50-55 & 11 & 3 & 27,2 \\ \text { Mais de 55 } & 3 & 1 & 33,3\end{array}$

Deixamos de apresentar os dados referentes às mulheres residentes à rua Itaboca porque ainda não havíamos terminado a colheita do sangue nessa rua no momento em que redigíamos êste trabalho.

Dois fatos despertam a nossa atenção neste segundo inquérito, quando comparado ao primeiro: o menor número de mulheres recenseadas e a menor taxa de reações sorológicas positivas observada.

$\mathrm{Na}$ época em que êste estudo foi realizado a zona do meretrício estava sendo severamente policiada, sendo todos os indivíduos do sexo masculino revis- 
tados antes de nela penetrar. O exercício da prostituição só era permitido até meia-noite; por essa razão a maioria das mulheres não residia nos bordéis, aí só chegando à noitinha, quando não era mais possível continuar a colheita de sangue.

Quanto ao menor coeficiente de reações positivas, nós o atribuimos ao uso frequente que essas mulheres vem fazendo da penicilina, desde um certo tempo.

Qualquer que seja a razão, porém, é bastante significativa a redução da taxa de prevalência da sífilis verificada em tão curto espaço de tempo, entre as prostitutas da zona do meretrício da capital de São Paulo.

\section{Considerações sôbre o problema da prostituição}

'E' um verdadeiro absurdo que o Estado reconheça e autorize a exploração da prostituição como negócio lícito; expeça licença comercial, autorizando-lhe, consequentemente, proteção; receba a título de contribuições, sua participação num comércio feito de degradação, ignomínia e sofrimento humano" ${ }^{137}$.

E' assim que um jornalista mexicano se refere ao problema da prostituição legalizada.

Para alguns indivíduos, com uma visão parcial do problema, ou direta ou indiretamente interessados na existência da prostituição, a localização de prostitutas em uma área especial da cidade apresenta uma série de vantagens:

$\left.1^{\circ}\right)$ Necessitando a população masculina solteira de dar vasão ao instinto sexual, a existência de casas de prostituição constitui uma salvaguarda para a família, pois de outro modo aumentariam os crimes e atentados sexuais, bem como as perversões.

$2^{\circ}$ ) Sendo a prostituição inevitável, e devendo existir casas de prostituição em uma cidade, é preferível que elas estejam localizadas longe das residências das famílias.

3.) A localização de prostitutas em uma área especial facilitaria a ação da polícia, assegurando-se, dessa maneira, a profilaxia do escândalo, da desordem e do crime.

4) A centralização dos alcouces da cidade favoreceria as medidas de de ordem sanitária em relação ao contrôle das doenças venéreas.

I - A existência de casas de prostituição não constitui salvặuarda para a família. Nos países onde elas foram fechadas não se notou nenhum aumento dos crimes sexuais. Não temos nenhuma notícia de que o fechamento dos bordéis do Mangue e da rua Conde Lage, no Rio de Janeiro, tenham sido responsáveis por alterações na vida daquela Capital.

Em Gary, cidade de Indiana (Estados Unidos), as casas de prostituição foram fechadas no comêço do ano de $1949^{139}$. Arthur Todd escrevendo no 
"Gary Pcst-Tribune" sôbre os crimes sexuais que tiveram lugar na cidade mostra os seguintes dados:

$\begin{array}{lll}\text { Em } 1947 \text { - Queixas relativas a crimes de ordem sexual } & 95 \\ \text { Em } 1948 \text { - Queixas relativas a crimes de ordem sexual } & 81 \\ \text { Em } 1949 \text { - Queixas relativas a crimes de ordem sexual } & 69\end{array}$

Em 1945, o Superintendente de Polícia de Terre Haute, ainda no Estado de Indiana, escrevia à Divisão de Proteção Social, de Washington: "Nossa lista de atentados de natureza sexual, baixou de $36 \mathrm{em} 1942$ para 14 em 1943, o primeiro ano do fechamento de nossa zona de meretrício, e para 4 em 1914" 138 .

A prostituição em Honolulu era um negócio de grandes rendimentos. Da ordem de 10 a 15 milhões de dólares por ano, até setembro de 1944, quando o Departamento de Polícia resolveu fechar as casas de tolerância. As observaçôes na ilha de Oahu ${ }^{139}$ revelam os seguintes dados, onze meses antes e onze meses depois do fechamento dos bordéis.

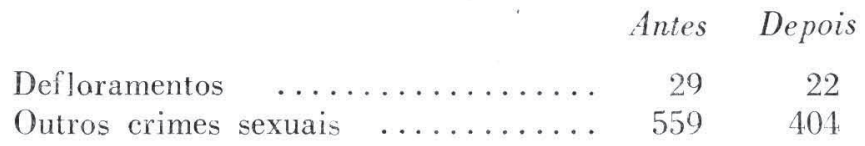

Aliás, é compreensível que o número de atentados e crimes sexuais diminua com o fechamento das casas de prostituição, pois elas constituem verdadeiros focos de excitação e de degeneração de indivíduos de tôdas as classes e, não raro, de menores.

A existência de uma zona de meretrício em São Paulo, bem como as inúmeras casas de "rendez-vous" espalhadas pela cidade não impedem que nesta Capital se perpetrem, com frequência alarmante, os mais tenebrosos crimes de natureza sexual.

II - E' absolutamente impossivel reunir as prostitutas de uma grande cidade em uma determinada área. Mesmo porque a maioria delas exerce a profissão clandestinamente e não é conhecida, ou pelo menos está fora do contrôle da polícia.

Segundo as estatísticas de todos os países onde a prostituição é ou era permitida, o número de clandestinas é inúmeras vezes superior ao de mulheres conhecidas e fichadas pela polícia.

Flexner ${ }^{140}$, estudando a prostituição na Europa, mostrou que na cidade de Berlim havia 5.000 prostitutas registradas, enquanto que o número de clandestinas era calculado em 25.000.

$\mathrm{Na}$ cidade do México ${ }^{141}$, em 1930, havia 5.971 prostitutas inscritas, e um número de clandestinas avaliado em não menos de 20.000. Em Madrí ${ }^{1+2}$, na mesma época, não chegavam a 5.000 as inscritas, mas as clandestinas deviam ultrapassar a cifra de 20.000. Fm Paris, em 1937, Frappa ${ }^{143}$ calculava em 202 as casas de prostituição, com 7.600 mulheres, mas o número de clandestinas estimado para a cidade era, segundo uns, 40.000, e segundo outros, até 100.000. 
Baliña ${ }^{144}$ calculava em 25.000 o número de mulheres dedicadas à prostituição na cidade de Buenos Aires, em 1935.

Na cidade do Rio de Janeiro, em 1925, segundo Teófilo de Almeida ${ }^{145}$ havia 310 casas de prostituição no centro da cidade, habitadas por 1.300 mulheres; e 600 no Mangue.

Em 1942, Hélio Gomes chegou a calcular o número de prostitutas clandestinas em 20.000; M. O. de Morais, em 30.000. Dessas mulheres a polícia tinha fichado $6.169^{146}$.

Em São Paulo não conhecemos nenhuma estimativa sôbre o número de prostitutas clandestinas, mas se aplicarmos a proporção encontrada em outras partes, entre as mulheres fichadas e as clandestinas, teremos em nossa Capital um número que deve oscilar entre 10.000 e 20.000.

O contrôle da prostituição clandestina é absolutamente impossível, pois as mulheres se espalham pela cidade, como dançarinas de cabarés, dancingss etc., ou se dissimulam nos ateliers de modas, institutos de beleza, pensões e rendezvous" nas zonas centrais da cidade.

Além de não existir, por conseguinte, o desejado afastamento das prostitutas do convívio com a sociedade, desde que apenas uma fração dessas mulheres é segregada, há ainda o grande inconveniente criado pela sua segregação: a elevação da prostituição ao seu grau mais intenso e abjeto.

$$
\begin{aligned}
& \text { III e IV - Quanto ao argumento de que a manutenção das prostitu- } \\
& \text { tas sob as vistas da polícia e do serviço de saúde seria } \\
& \text { de grande alcance sanitário, carece êle de todo fundamen- } \\
& \text { to. Em primeiro lugar, como já dissemos, as meretrizes } \\
& \text { fichadas não representam senão uma parcela do número } \\
& \text { total de meretrizes de uma cidade. Em segundo lugar, } \\
& \text { os exames periódicos das mulheres se mostraram tão ine- } \\
& \text { ficazes sob o ponto de vista sanitário, que todos os países } \\
& \text { que adotavam a regulamentação da prostituição reso!ve- } \\
& \text { ram abandoná-la por não oferecer a garantia sanitária } \\
& \text { que se imaginava, por ser onerosa e por ser imoral, pois } \\
& \text { coloca o Estado no papel pouco simpático de alcoviteiro } \\
& \text { amoroso. }
\end{aligned}
$$

As zonas de meretrício de todos os lugares do mundo são sempre um foco de desordem e de crime, pois são frequentadas por indivíduos da pior espécie. A polícia, quando muito, evita que o número de desordens e de crimes seja mais elevado.

Os venereologistas de todo o mundo estão de acôrdo que a regulamentação da prostituição deve ser banida de todos os códigos sanitários modernos.

Embora não pretendamos enumerar neste trabalho as razóes pelas quais a regulamentação não oferece garantia sanitária contra as doenças venéreas, não podemos deixar de lembrar a observação do Dr. E. Ramirez ${ }^{147}$ em 1925. Em 100 prostitutas inscritas na Inspetoria de Saúde do México, que haviam passado pelo exame médico e declaradas isentas de doença venérea, aquêle autor encontrou $100 \%$ de infecções gonocócicas, repetindo o exame horas mais tarde com a reativação pelo nitrato de prata. 


\section{SUGESTÃO PARA A SOLUÇ̃̃O DO PROBLEMA DO MERETRÍCIO FM SÃO PAULO}

Entre as medidas a serem propostas poderíamos pensar, em primeiro lugar, em combater as causas que dão origem à prostituição, como as medidas mais eficientes, e que poderiam cortar o mal pela raiz. Ora, tais medidas implicariam em reformas sociais, e essa não é a função precípua do sanitarista.

A outra medida, de muito mais agrado dos legisladores e daqueles que estão incumbidos de zelar pelo povo, é ignorar o problema. Sanitaristas, sociólogos, religiosos, autoridades civis e militares empregam a tática do avestruz, e não tomam conhecimento da prostituição que invade a cidade, atentando contra o Código Penal brasileiro:

“Casa de prostituição. Art. 229 - Manter, por conta própria ou de terceiros, casa de prostituição ou lugar destinado a encontros para fins libidinosos, haja ou não intuito de lucro ou mediação direta do proprietário ou gerente".

A regulamentação do meretrício é medida condenada em todo código sanitário moderno e, por vários motivos, alguns dos quais já foram discutidos páginas atrás, não deve ser sugerida, em hipótese alguma.

Poderíamos então, não imitar outros países civilizados, mas cumprir apenas o nosso Código Penal, o que implicaria na repressão da prostituição.

Repressão é o têrmo adequado, pois proibição ou supressão do meretrício é simplesmente utópico, dentro do atual estado de coisas.

Não se trata, com efeito, de acabar com a prostituição, mas de fazer um esfôrço concentrado das organizações sanitárias, legislativas, judiciais, policiais, civis e militares, para reduzir a promiscuidade sexual, principalmente aquela causada pela prostituição organizada em comércio público. Isto implicaria em reduzir à sua expressão mínima os males originados pelo meretrício.

Êsse programa de repressão, no entanto, quando não é perfeitamente executado pelas autoridades, é contraproducente.

O exemplo do Rio de Janeiro e de Paris, onde a zona do meretrício foi extinta mas pouco durou a repressão policial sôbre as atividades das meretrizes clandestinas, resultando apenas na disseminação das mulheres pela cidade. mostra que não estamos amadurecidos para executar tal programa de contrôle. Possivelmente aconteceria o mesmo nesta Capital.

Como é necessário fazer alguma coisa enquanto se aguarda o momento em que govêrno e povo estejam em condições de executar e aceitar as medidas necessárias para o combate à prostituição, sugerimos uma medida contemporizadora: 
O tratamento de tôda prostituta contagiante pelos processos modernos e rápidos, completamente gratuito, e desenvolvimento de um programa intenso de educação sanitária na zona do meretrício.

Utilizar o Posto Anti-Venéreo da rua Carmo Cintra, na zona do meretrício, que está sob a direção do Departamento de Saúde da Capital, o qual, além das suas funções de preventório, seria o centro de onde partisse uma campanha de educação sanitária intensa e permanente entre as moradoras dos prostíbulos. Por intermédio de educadores sanitários, assistentes sociais ou pessoas especialmente trienadas para êsse fim, tôda prostituta seria convencida a se submeter, espontâneamente, a exame e tratamento.

Não se deveria utilizar nunca métodos que, mesmo de longe, lembrassem uma regulamentação sanitária, como o uso de caderneta, por exemplo.

\section{APRESENTA A SífILIS TENDENCIA AO DESAPARECIMENTO?}

Thomas Parran ${ }^{148}$, quando diretor do Departamento de Saúde Pública dos Estados Unidos afirmou, em 1936, que o desaparecimento da sífilis poderia ser feito em uma geração se o problema fôsse atacado com determinação suficiente, dinheiro e atividade.

Em 1948, o mesmo autor, em mensagem enviada à Associação Americana de Higiene Social ${ }^{149}$ tratava de responder à pergunta: "Está a sífilis desaparecendo?"

Móstrava, então, que em 1938, nos Estados Unidos, cêrca de 16 pessoas em cada 100.000 morriam de sífilis. Em 1946 cêrca de 10 pessoas morriam de sífilis, isto é, a taxa havia caído para mais de $1 / 3$.

A redução da taxa de mortalidade infantil devida à sífilis foi mais dramática. Em 1938, 63 em cada 100.000 crianças nascidas vivas morriam de sífilis. Em 1945 essa taxa caiu para .25 por 100.000 .

Em 1938, 10\% de tôdas as primeiras admissões aos hospitais de doenças mentais eram devidas à sífilis. Em 1945 essa percentagem foi reduzida a 6,6.

Em 1938 foram notificados, nos Estados Unidos, 480.000 casos de sífilis, o que significava uma taxa de 3,7 por 1.000 habitantes. Em 1943 o "Selective Service", através de exames físicos e de laboratório, encontrou 4,4 por 1.000 . Desde então, ela declinou gradualmente até 399.000 casos em 19.17, ou seja 2.8 por 1.000 .

Conclui Parran que, à custa de um intensivo programa de descobrimento de casos, associado aos tratamentos rápidos, com a cooperação das sociedades de higiene social, igrejas, escolas etc., e com a ajuda de uma legislação adequada, que combata àquelas condições que costumam encorajar a promiscuidade sexual e prejudicar a estabilidade da família, estaremos próximos da eliminação da sífilis dos grandes problemas de Saúde Pública.

Heeren ${ }^{150}$ mostrou que, em Iowa, as taxas de mortalidade e de admissão aos estahelecimentos de doenças mentais, devidas à sífilis, diminuiram de quase $40 \%$ desde 1936. Acrescenta o autor, entretanto: "Baseado nos exames de sangue dos indivíduos que se casam e das mulheres que dão à luz, não tem havido grande declínio na prevalência da sifilis durante os últimos sete anos". 
Acredita que o reservatório de sífilis continua, e acha que se deva continuar o programa intensivo de tratamento e de procura de casos.

Aufranc ${ }^{151}$, analisando a evolução da sífilis nos Estados Unidos, depois de 11 anos de ajuda federal no contrôle das doenças venéreas, conclui:

a) Em 1949 a mortalidade infantil devida à sífilis foi cêrca de $1 / 5$ daquela verificada em 1938.

b) A mortalidade geral devida à sífilis foi reduzida de $48 \%$.

c) Admissões em instituições que tratam de doenças mentais; devidas à sífilis, foram reduzidas de $34 \%$.

d) $\mathrm{O}$ número de notificações de sífilis diminuiu consideràvelmente durante os últimos quatro anos.

Pensa êsse autor que a penicilina seja um dos fatôres responsáveis pelo decréscimo da sífilis, mesmo porque o uso dêsse antibiótico para outras doenças, além da sífilis, é generalizado; mas não acredita que o uso exclusivo dessa arma terapêutica possa ser responsável pelo desaparecimento da moléstia.

A sífilis não é doença que leva o indivíduo a procurar imediatamente o médico, e também porque existem inúmeras regiões no mundo, e até nos kstados Unidos, onde a incidência da moléstia é elevada e os recursos médicos são escassos.

Stokes ${ }^{152}$ e Koch $^{153}$ acham que apenas a penicilina não poderá resolver o problema das doenças venéreas, em virtude de haver uma série de fatôres sociais e educacionais a elas relacionados.

Em 1949, seis anos após o emprêgo da penicilina como medicamento de eleição no combate à sífilis, os Estados Unidos ainda apresentavam os seguiutes dados:

a) 150.000 pessoas infectadas, sendo que cêrca de 80.000 não descocobertas.

b) 6.000 sifilíticos encaminhados a hospitais de doenças mentais.

c) 14.000 crianças com sífilis congênita (casos conhecidos).

d) 13.000 pessoas mortas devido ì sífilis.

e) Existiriam na população cêrca de 3 milhões de sifilíticos, segundo os cálculos prováveis.

Em 1950, Clark ${ }^{154}$ presidindo à reunião anual dos venereologistas norteamericanos em Washington, abordou o tema "Não constituem mais problema as doenças venéreas?". Analisando as taxas de incidência de sifilis do ano anterior (1949), declarou que essa moléstia ainda constitui um problema nos Estados Unidos, o que se deve, principalmente, ao grande número de casos não descobertos.

Há cêrca de 20 anos atrás Thomas Parran dizia que "A sifilis nunca poderá ser controlada enquanto existir mais de metade dos casos que não são conhecidos senão depois de 1 ano do aparecimento da moléstia". 
Segundo Clark, todo o otimismo em relação à possibilidade de um contrôle imediato das doenças venéreas nos Estados Unidos abrangendo o país inteiro é ainda prematuro.

Moore ${ }^{15}$ acha que, estimulados pelos progressos dos conhecimentos recentes, muitos sanitaristas olham o futuro das doenças venéreas com excessivo otimismo. Acreditam que a aplicação dos atuais conhecimentos é suficiente para levar a caho o contrôle dessas doenças e, talvez mesmo, promover a sua erradicação.

A fim de se ter uma idéia sôbre o fundamento de tal otimismo, diz êle, deve-se analisar a experiência passada. Para isso é necessário saber:

$1^{\circ}$ ) os dados que refletem a incidência da sífilis na população antes de 1910, isto é, antes da aplicação de métodos científicos de contrôle;

2) os principais fatôres que determinam flutuações na incidência, e sua influência durante êsse período;

3) até que pontos tais fatôres são ainda operantes desde 1910;

4.) qual o efeito das medidas representadas pelas aquisições da medicina moderna.

As áreas geográficas e os períodos de tempo sôbre os quais possuimos dados relativos à morbidade e mortalidade pela sífilis são muito limitados.

Fatôres de ordem moral, devido à maneira de transmissão da moléstía, e a falta de sintomatologia do período latente, fazem com que iriumeros casos não sejam descobertos.

Além disso, a maneira pela qual as doenças venéreas são notificadas varia muito segundo os países, e são raros os dados epidemiológicos dignos de estudo.

As flutuações da taxa de incidência das doenças venéreas não significam, obrigatoriamente, a incidência de uma infecção em particular. A taxa de uma doença venérea pode permanecer estacionária, ou até mesmo elevar-se, enquanto a taxa das outras caem, como acontece, por exemplo, com a gonorréia e a sifilis, presentemente, nos Estados Unidos.

Sôhre a existência de um declínio da morbidade e mortalidade pela sífilis desde 1910, os dados relativos à população civil não são suficientes para uma conclusão, com exceȩão daqueles referentes à Escandinávia.

As informações referentes aos militares, porém, nos trazem algum auxílio. No exército norte-americano a proporção de sífilis era de 68 casos por 1.000 em 1861, 17 por 1.000 em 1914, e cêrca de 5 por 1.000 em 1941. Ésses dados combinados com os de outros exércitos e com a experiência da população civil escandinava e inglêsa sugerem que a incidência da sífilis na Europa ocidental e nos Estados Unidos caiu de maneira significativa desde 1910, e se encontra em declínio.

O declínio acelerado da morbidade não começou senão cêrca de 10 anos após as grandes descobertas no campo da sífilis (1905-1910), havendo aumento da incidência durante a $1^{*}$ e a $2^{a}$ guerra mundial. 
São discutíveis as causas que teriam contribuido para tais declínios. Alguns fatôres poderiam ser lembrados:

a) Seria um fenômeno natural às moléstias infecciosas; variaçōes das relações hospedeiro-parasita.

b) Resultaria da melhoria de condições sócio-econômicas nesses países.

c) Seria resultante da maior estabilidade das populações após longo període de instabilidade.

Quanto ao declínio posterior a 1910, Moore acredita que seja devido às medỉidas modernas de contrôle sanitário, principalmente devido ao tratamento de milhões de pessoas infectadas, educação sanitária e pesquisa de casos. Devido a isso, conclui aquêle autor, a mortalidade caiu mais depressa que a morbidade.

Deve-se esclarecer que a maior parte do declínio da sífilis se verificou durante a era de tratamento pelos metais pesados, isto é, antes de 1946, e não há ainda evidências que indiquem estar a taxa de declínio sendo acelerada nestes últimos anos pela introdução da penicilina. Segundo Moore, será necessário mais uma década a fim de se poder tirar uma conclusão definitiva.

Quanto à questão de saber se a queda da incidência da sífilis se processou de maneira mais acentuada nos países de elaborado programa de contrôle, como os Estados Unidos, do que em outros onde pouco ou nada se fez desde 1910, a não ser o tratamento das pessoas infectadas, como é o caso da Dinamarca e Suécia, parece não acusar grande diferença. O declínio foi, pràticamente, o mesmo. Os dados estatísticos, no entanto, ainda são escassos e o período de observação muitỏ curto, a fim de se poder chegar a uma conclusão.

Deve-se acrescentar, no entanto, que, dificilmente, uma doença infecciosa poderá ser erradicada, apenas pela prática de se tratar as pessoas depois que elas foram infectadas.

O caso da sífilis congênita é uma boa ilustração. Os sanitaristas chegaram a acreditar que poderia se esperar o desaparecimento da sífilis congênita pelas medidas tomadas em relação às gestantes, isto é, exame de sangue e tratamento quando necessário. Por certo tempo parecia que a sífilis congênita ia desaparecendo, mas a curva tornou a elevar-se e tem se mantido constante nos últimos seis anos, nos Estados Unidos.

Há doenças que podem ser erradicadas de um país e vicejar em outros. Com a sífilis há muito pouca probabilidade que isso aconteça, pois as facilidades de transportes tornam as populações cada vez mais instáveis. Enquanto existir áreas onde a sífilis for endêmica será muito difícil que um país evite a existência de focos de infecção em seu território, e de novas epidemias da moléstia.

Segundo as conclusões de Moore, o presente declínio verificado em relação à incidência da sífilis, com exceção da Escandiávia, ainda não é significante para se entrever um completo contrôle da moléstia. 
Enquanto não houver processos científicos mais aperfeiçoados em relação à sífilis, imunização em massa por exemplo, não se poderá pensar na sua erradicação.

Quanto ao Brasil, nenhuma informação é fornecida sôbre a evolução da sífilis nestes últimos anos, pela falta de dados estatísticos.

Em São Paulo, sabemos apenas, pela experiência dos que trabalham em serviços especializados, que desde há uns 10 anos começaram a rarear os aneurismas e as formas cutâneas gomosas da sífilis nos pacientes de ambulatórios e dispensários.

De há poucos anos para cá também as formas primária e secundária da moléstia têm rareado. Acredita-se que seja devido ao uso generalizado que a população faz da penicilina, a qual já está sendo "receitada" pelo farmacêutico, "larga manu", para as infecções venéreas.

Essa razão, ou o declínio espontâneo da moléstia, como querem alguns, são considerações de ordem teórica que, dificilmente, poderemos comprovar. $\mathrm{Na}$ prática, o que se nota é um declínio acentuado nas taxas de incidência e prevalência da lues, seja através das estatísticas dos serviços especializados. seja através de inquéritos sorológicos.

Em 1937 Vieira Macedo encontrou taxas de 8.39 e $8.87 \%$ entre convocados do Exército e soldados da Base Aérea; em 1950 e 1951 as taxas encontradas entre militares do Exército, pelo mesmo autor, oscilavam em volta de $3 \%$, o que, aliás, foi confirmado por Mammana e Hidal.

Entre os universitários paulistas encontramos 15 casos de reações sorológicas positivas entre 739 matriculados no ano de 1950. o que dá uma taxa de positividade de $2,0 \%$, contra $4,3 \%$ verificada no período de $1945-1948$, em um trabalho nosso.

Nos serviços de doenças venéreas dos centros de saúde da capital de São Paulo, durante os anos de 1948, 1949 e 1950, foram atendidas 55.253 pessoas. Dêsse total foram fichados, como portadores de doenças venéreas 7.193 , ou seja $13.1 \%$

Analisados os dados anuais encontrados observamos um aumento do número de pessoas que procuraram os serviços, de 1948 a 1950 , de mais de $27 \%$. O número de portadores de doenças venéreas, no entanto, caiu, nesse período, de $3 \%$.

$\begin{array}{cccc}\text { Ano } & \text { Pessous inscritas } & \text { Portadores de D.Y. } & \% \\ 1948 & 15.816 & 2.370 & 14,9 \\ 1949 & 17.589 & 2.269 & 12,8 \\ 1950 & 21.848 & 2.554 & 11,7\end{array}$

Dêsses portadores de venéreas, em $1948,75,5 \%$ acusava a infecção sifilítica; em 1949, 74,1\% e em 1950, 65\%.

Tais dados são muito relativos. Contribuem apenas para a suposição de que a taxa de sífilis na população paulistana esteja diminuindo gradativamente. Do mesmo valor são as informações colhidas no Centro de Aprendizado da Faculdade de Higiene e Saúde Pública. Reações sorológicas aí realizadas, durante o período 1932-1942, mostraram as seguintes taxas de positividade: 


$\begin{array}{rrcccc}\text { Ano } & \text { RW. } & \text { RW. pos. } & \text { Ano } & \text { RW. } & \text { RW. pos. } \\ 1932 & 908 & 29,84 \% & 1938 & 2.403 & 9,19 \% \\ 1933 & 1.869 & 18,24 \% & 1939 & 3.699 & 10,30 \% \\ 1934 & 3.220 & 14,53 \% & 1940 & 3.106 & 6,69 \% \\ 1935 & 3.016 & 12,00 \% & 1941 & 2.558 & 8,63 \% \\ 1936 & 2.295 & 10,08 \% & 1942 & 2.999 & 8,96 \% \\ 1937 & 2.2 \% 6 & 12,66 \% & & & \end{array}$

Durante o período de 1950 e primeiro semestre de 1951 foram realizadas 2.225 reações de Wassermann e Kahn nesse Centro de Aprendizado, verificando-se um total de 122 reações positivas, ou seja $5,48 \%$.

Gomes de Matos e colaboradores ${ }^{156}$, examinando 766 crianças de 3 a 24 meses de idade na Clínica Infantil do Ipiranga, entre 1947 e 1948, encontraram $2,21 \%$ de reações sorológicas positivas. Em 1950-51, entre 123 crianças examinadas, foi observado apenas 1 caso de reação sorológica positiva para a sífilis, ou seja $0,8 \%{ }^{157}$.

A diferença mais impressionante, no entanto, é aquela encontrada nos dois inquéritos que realizamos entre as meretrizes. Em 1918 encontramos $83.6 \%$ de reações positivas e, em 1951, 35,3\%.

A própria prostituição parece que era mais desenvolvida tempos atrás do que na época presente. Moraes Leme ${ }^{158}$, em tese de doutoramento, publicada em 1926, conta que existiam em São Paulo, em 1925, 531 bordéis e 221 casas de "rendez-vous". Ora, em relação à população da cidade, na época. ésses números são alarmantes. Em 1948 registramos 150 bordéis na zona do meretrício. e o número de casas de "rendez-vous" espalhadas pela cidade, ainda que não dispuséssemos de dados oficiais, não ia, talvez, além de uma centena. Em 1951 o número de casas de prostituição da zona do meretrício apresentava-se ainda mais diminuido.

Haverá diferença entre a taxa de prevalência da sifilis em São Paulo

e outras regiñes do Brasil?

Em 1942, Barros Barreto, Costa e Teixeira ${ }^{159}$ publicaram um trabalho mostrando as percentagens de reações sorológicas positivas para a sífilis observadas entre gestantes matriculadas nos Serviços de Assistência Pré-Natal dos Centros de Saúde das capitais dos Estados:

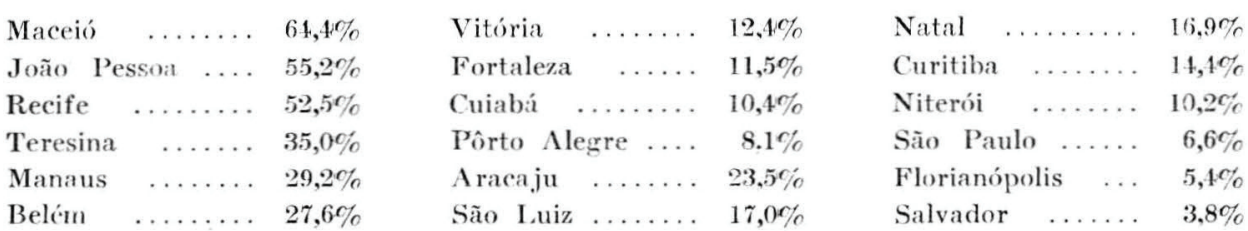

Vê-se, pelo resultado encontrado que, com exceção de Salvador, as taxas mais baixas dizem respeito a Estados do sul. No entanto, não acreditamos que taxas obtidas nesse trabalho possam ser comparáveis porque, possivelmente, elas provêm de observações diferentes, feitas com diferentes técnicas, entre grupos 
sociais diversos. Restaria, ainda mesmo com a eliminação dêsses fatôres, a dúvida de estar a bouba influindo, como causa de maior positividade das reaçóes sorológicas nos Estados do norte.

Essa dúvida foi a que nos assaltou quando, realizande o inquérito sorológico entre os operários de São Paulo, encontrávamos maior taxa de positividade em fábricas onde operários nortistas existiam em maior proporção. Infelizmente, nem tôdas as fichas de operários com exame positivo faziam referências à sua origem natal, razão pela qual deixamos de apresentar dados coneretos.

Fizemos, no entanto, em colaboração com o assistente social do SESI, Sr. Octany Silveira da Mota, um inquérito entre os operários da Capital, no próprio local de trabalho, isto é, nas fábricas.

Foram entrevistados 501 operários originários da própria Capital, e 77 operários chegados do norte do país há menos de 1 ano.

Cêrca de $80 \%$ dos operários paulistas, e $90 \%$ dos operários nortistas estavam compreendidos entre os grupos de idade de 20 a 40 anos. Mais de $90 \%$ dos operários, em ambos os grupos, eram de côr branca. Todos eram do sexo masculino.

Dos operários paulistas, 70 acusavam passado venéreo, o que dá uma taxa de $13,9 \%$. Entre os operários nortistas 31 acusavam passado venéreo, isto é, $40,2 \%$.

A gonorréia foi mencionada em 10,9\% dos operários paulistas e em 20,7\% dos operários nortistas.

Quanto à sífilis, infelizmente, as informações foram falhas, pois os indiví. duos, via de regra, usavam a expressão popular pela qual é conhecida a ulceração genital, e que tanto pode dizer respeito ao cancro mole como duro. Acreditamos, porém que, seguindo a proporção encontrada para o grupo geral das doenças venéreas, a sifilis deve ser muito mais frequente entre os operários nortistas entrevistados.

A nossa pequena observação nesse trabalho vem contribuir para o esclarecimento da dúvida já mencionada; se a maior taxa de reações positivas encontradas entre os indivíduos do norte seria devida à presença da bouba naquela região.

Baseamo-nos, apenas, nos acidentes venéreos genitais dos indivíduos entrevistados, sem levar em conta as reações sorológicas e verificamos que, de fato, êles foram muito mais frequentes entre os nortistas.

Ainda nos cabe, porém, uma hipótese para explicar a diferença de taxas encontradas entre operários do norte e da capital de São Paulo, em relação às doenças venéreas.

O grupo de nortistas examinado era composto de imigrantes, casados ou solteiros, porém quase todos tendo abandonado as famílias, em busca de melhores emprêgos e salários, constituindo, assim, um grupo migratório instável.

Não seria êsse o fator principal, responsável pela maior promiscuidade sexual e, consequentemente, maior incidência de doenças venéreas entre tais indivíduos? Não teriam os operários paulistas, também, uma taxa de sífilis e outras doenças venéreas mais elevada, se colocados nas mesmas condições? 
Infelizmente, não temos dados suficientes para esclarecer melhor a questão. Seria necessário que um inquérito realizado nos Estados do Norte, comparável ao que estamos realizando em São Paulo, viesse nos auxiliar.

Em 1940, Porto e Brito ${ }^{160}$ realizaram um censo sorológico entre imigrantes nacionais, chegados à capital de São Paulo, e obtiveram 25\% de positividade.

Tudo leva a crer que a taxa de prevalência da sífilis seja mais baixa na população paulista do que em algumas regiões do Brasil, principalmente do norte, porém não passa de conjecturas, ẹm vista da quase total ausência de dados estatísticos colhidos satisfatòriamente.

Não podemos deixar de mencionar, ainda, como contribuição ao que dissemos acima. as nossas observações entre soldados da Fôrça Pública do Estado, aquartelados na capital de São Paulo.

Através de um inquérito sorológico realizado no Batalhão de Guardas e no Regimento de Cavalaria, verificamos que:

A taxa de positividade das reações foi de $7,1 \%$ entre 239 soldados paulistas, e $27,7 \%$ entre 18 soldados chegados a São Paulo do norte do país há pou$\cos$ meses, no Batalhão de Guardas.

No Regimento de Cavalaria foi verificada uma taxa de $16,3 \%$ de reaçóes positivas entre 153 soldados paulistas e $33,3 \overline{\%} \%$ entre os 12 soldados recém-chegados do Norte.

Infelizmente, as amostras são pequenas demais para uma generalização. Aguardamos, porém, que outros estudiosos do assunto façam verificações em suas cidades e Estados, a fim de se ter, dentro em breve, uma idéia sôbre as diferenças das taxas de prevalência da sífilis nas diversas regiões do Brasil.

\section{O PORTADOR DE SífILIS E OUTRAS DOENCAS VENEREAS, SOB O PONTO DE VISTA PSICOLOGICO}

Não há dúvida que a sífilis e as outras doenças venéreas devem a sua larga disseminação no grupo humano devido ao fator "promiscuidade sexual". Quer dizer, se. o homem e a mulher não mantivessem relações sexuais com mais de uma pessoa, as doenças venéreas já teriam deixado de existir há muito tempo.

Em países como o nosso, onde a promiscuidade sexual feminina está, pràticamente, limitada às prostitutas, é a prostituição considerada a maior fonte de doenças venéreas, aliás com razão. No entanto, em países como os Estados Unidos, onde a repressão do meretrício é severa, o número de prostitutas clandestinas não pode ser o único responsável pẻla disseminação das doenças ve. néreas.

Todos os venereologistas norte-americanos concordam que a repressão da prostituição baixou mas não extinguiu o número de contágio venéreo. Naquele país as mulheres deixaram de se entregar por dinheiro, mas o fazem por outras razões.

A emancipação da mulher não se limita exclusivamente ao terreno cultural e político. Substituindo ou acompanhando o homem em todos os períodos crí- 
ticos da vida da nação, lutando e sofrendo na guerra da mesma maneira que o seu companheiro do sexo masculino, desejam as mulheres modificar as injunções que pesam sôbre a sua vida sexual, em contraste com a extrema liberdade masculina, nesse terreno. Até mesmo nos países latinos, onde a sociedade é intransigente em relação ao preconceito do hímen, já se começa a notar, nos centros mais adiantados, certa tolerância a êsse respeito.

Daí a razão dos venereologistas voltarem sua atenção para o problema da promiscuidade sexual, a fim de verificar até que ponto êle pode ser resolvido, ou, pelo menos, como torná-lo insignificante, de maneira que o problema das doenças venéreas possa ser atacado pela raiz.

Para os moralistas, a promiscuidade sexual seria resultante da falta de moral e de religião. Para alguns seria ausência do fator educação e, para outros, resultaria do apetite sexual, mais desenvolvido em certos indivíduos.

Kinsey, em seu estudo sôbre o comportamento sexual do homem nos Estados Unidos, publicado em 1948, observou que os indivíduos de nível cultural e educacional inferior são muito mais sujeitos à promiscuidade sexual ${ }^{161}$.

Aos psiquiatras, no entanto, cabe o estudo mais aprofundado da questão e, de fato, desde há algum tempo, vêm sendo publicados trabalhos nesse sentido.

Dos mais importantes é o estudo realizado por um grupo de psiquiatras de São Francisco (EE. UU.), 1943-1947, entre indivíduos matriculados na clínica de doenças venéreas daquela cidade ${ }^{162}$.

Foram examinados 620 pacientes, sendo 365 mulheres e 255 homens. Entre as mulheres entrevistadas apurou-se que a sua reação em relação ao ato sexual era:

$\begin{array}{ll}\text { agradável } & 39 \% \\ \text { desagradável } & 13 \% \\ \text { indiferente } & 13 \% \\ \text { sentimentos confusos } & 35 \%\end{array}$

Um outro investigador, Palmer ${ }^{163}$, em estudo semelhante, também não encontrou indicações de que houvesse maior sensualidade entre os promíscuos por êle examinados do que entre um grupo não selecionado de indivíduos. Alguns, mostraram mesmo, sensualidade abaixo do normal.

Ainda segundo os estudos realizados em São Francisco, através do teste de Roscharch, apurou-se que os indivíduos promíscuos apresentavam "uma prevalência de imaturidade de caráter, e uma falta de habilidade e de vontade para assumir responsabilidades em relação ao seu comportamento".

Foi verificado que, em $90 \%$ dos indivíduos estudados, havia desajustamentos motivados por causas inconscientes.

O comportamento sexual era usado, frequentemente, como motivo de:
a) superar frustrações*
b) desafiar as autoridades
c) chamar a atenção sôbre sua pessoa 
d) castigar os pais

e) rivalidade mãe-filha

f) provar a feminilidade em mulheres com tendências masculinas

g) auto-punição através da gravidez, doenças venéreas, prisão etc.

h) sentimentos sadi-masoquistas, através dos quais o indivíduo procura ser infectado, e infectar os outros.

Na história das mulheres havia, quase sempre, um homem bruto, pai ou padrasto.

As conclusões do estudo de Palmer sôbre a promiscuidade sexual masculina mostram que ela está condicionada a uma incapacidade de sentimentos profundos para qualquer mulher, ou a uma mistura deficiente dos sentimentos de amor e sexualidade.

Freud já havia estudado a personalidade do D. Juan, o homem que não conseguiu atingir a maturidade sexual, sempre em busca do inatingível ${ }^{164}$.

Brody ${ }^{165}$ procurou estudar o caráter da pessoa que mais frequentemente adquire doença venérea. Para isso entrevistou soldados norte-americanos internados em hospitais, e cêrca de 4.000 pacientes de venéreas, através de suas fichas. Os resultados da sua investigação mostraram que o soldado que adquire doença venérea tem menos educação do que os outros soldados, é descuidado, irrefreado e pẹssoa fàcilmente influenciável; bebe mais e não se ajusta bem à vida militar. Em geral a sua atividade sexual iniciou-se mais cedo e é um fator importante em sua vida. E' menos exigente na escolha de parceiro sexual. Ao que parece não há diferença entre os soldados filiados aos diversos tipos de religião.

Wittkower ${ }^{166}$, psiquiatra do Departamento de Dermatologia do Hospital São Bartolomeu, em Londres, apresenta também um estudo sôbre os aspectos psicológicos das doenças venéreas. Sua opinião é a de que os indivíduos portadores de doenças venéreas são frequentemente, emocional, sexual e socialmente imaturos, embora tenham alcançado a maturidade física e intelctual. Essa imaturidade é mais evidente nas pessoas habitualmente promíscuas do que naquelas que só o são ocasionalmente. Os principais fatôres que os arrastam à promiscuidade são a necessidade de afeição e a existência de situações que produzem ansiedade ou ressentimento. A atividade sexual seria, portanto, a válvula de escapamento da tensão, ansiedade ou ódio interior.

Em conclusão: Além dos fatôres relacionados a causas econômicas e sociais, tais como baixo padrão de vida do povo, falta de instrução e de ambientes de recreação sadia etc., os conflitos internos, conscientes ou inconscientes, representam, também, um papel muito importante na disseminação da sífilis e outras doenças venéreas.

Verificamos que há uma série de fatôres que contribuem para o comportamento sexual promíscuo do homem, o qual é ainda agravado, principalmente, por:

a) excitamento erótico permanente, através do cinema, teatro, rádio, anúncios, revistas, conversas etc.; 
b) existência de aglomerações humanas, tal como acontece nas cidades, onde os atos do indivíduo se perdem no anonimato da multidão;

c) a facilidade de meios de transporte. Stokes chega a afirmar que, depois do leito, é.o automóvel o maior veículo de disseminação das doenças venéreas;

d) a instabilidade das populaçöes. Resultante da facilidade de transporte, os indivíduos se locomovem frequentemente e têm maior oportunidade de encontrar novos parceiros amorosos.

Um dos fatôres que torna o contrôle das doenças venéreas mais complicado do que o de outras doenças transmissíveis é o fato do doente venéreo ser considerado aos olhos da sociedade como um delinquente moral.

Os males venéreos são encarados, ainda hoje, como merecido castigo àqueles que levam uma vida sexual considerada condenável, e o portador de uma doença venérea nunca é merecedor dos sentimentos de comiseração. Está tão arraigado êsse caráter punitivo das doenças venéreas que até médicos se deixam influenciar por êle. A mesma severidade de julgamento, entretanto, não existe em relação aos indivíduos que padecem dos efeitos das libações alcoólicas ou da glutoneria, os quais são encarados com hem humorada condescendência.

Como resultante dessa atitude em relação às doenças venéreas e do conflito psicológico que se estabelece, frequentemente, no indivíduo infectado, pode haver desenvolvimento de sentimentos de culpa, os quais podem assumir proporções graves. Não é incomum, por exemplo, o aparecimento de impotência sexual. de fundo psíquico, após uma contaminação venérea.

Luehrs $^{167}$ verificou que o sentimento de culpa do portador de doença venérea diz respeito à sociedade, ao grupo, ao ego e à religião. Acredita êsse autor que tal sentimento de culpa pode levar o indivíduo à repetição do ato, através de um mecanismo psicológico comparável àquele que induz o criminoso a voltar ao lugar do crime. As medidas de profilaxia, de ordem psicológica, em relação ao portador de venéreas seriam, por conseguinte, da mais alta importância no combate à sífilis e demais doenças venéreas.

\section{SUMÁRIO F CONCLUSÕES}

I - A sífilis. por várias razões, merece um destaque especial no estudo das doenças venéreas, as quais constituem um importante problema de saúde pública.

Para o estabelecimento de um programa de contrôle da sífilis, em uma região, se faz necessário o conhecimento das taxas de incidência e prevalência dessa moléstia. No entanto, nem São Paulo nem o resto do Brasil apresentam dados precisos sôbre a frequência da sífilis na população. 
II - O inquérito sorológico feito em massa é um dos melhores processos para o estudo da prevalência da sífilis em uma população, mesmo levando em conta as suas diversas causas de êrro.

III - O problema da sífilis na Indústria é considerado como sendo dos mais relevantes pelo contingente de horas perdidas de trabalho e pelo número de pensões e aposentadorias que essa moléstia acarreta.

Em São Paulo, cidade industrial por excelência, o estudo da sífilis entre os operários é de importância indiscutível.

IV - Um estudo realizado entre 1950-1951, na capital paulista, revelou uma taxa de positividade das reações sorológicas em 3,81\% dos 20.892 operários examinados.

V - Foi confirmada a impressão de que a taxa de positividade aumenta, de maneira mais acentuada, até cêrca dos 30 anos de idade, permanecendo mais ou menos estável até cêrca dos 60 anos, para diminuir em seguida.

VI - Os operários do sexo masculino apresentaram taxa de positividade das reaçôes sorológicas mais elevada do que o sexo feminino.

VII - Os operários brancos apresentaram taxa de positividade mais baixa do que a observada entre os pardos e pretos.

VIII - Entre os operários casados a percentagem de reações positivas para a sifilis foi mais elevada do que a encontrada entre os solteiros.

Os operários casados, do sexo masculino, apresentaram taxa mais elevada do que os solteiros $\left(\chi^{2}=12,52\right.$, significante ao nível de $\left.5 \%\right)$.

Os operários casados, do sexo feminino, apresentaram taxa mais elevada do que os solteiros $\left(\chi^{2}=50,71\right.$, significante ao nível de $\left.5 \%\right)$.

IX - Não foi constatada diferença significante para a taxa de positivi. dade das reações, entre os operários casados e viúvos.

Para os operários casados e viúvos, do sexo masculino, $\chi^{2}$ foi igual a 3,84 , e para o sexo feminino $\chi^{2}=0,90$.

$\mathrm{X}$ - Foi observada uma taxa de reações positivas mais elevada entre os operários nacionais do que entre os estrangeiros.

Para os operários do sexo masculino, brasileiros e estrangeiros, $\chi^{2}$ foi igual a 50,71, e para aquêles do sexo feminino, brasileiros e estrangeiros, $\chi^{2}$ apresentou o valor de 6,63 significante ao nível de $5 \%$.

XI - Parece existir uma relação entre o fator educacional ou cultural e a taxa de incidência e prevalência da sífilis. Todos os autores concordam que a percentagem de sifilis entre os estudantes é baixa.

Um estudo realizado através das fichas dos estudantes da Universidade de São Paulo, matriculados no Centro de Aprendizado da Faculdade de Higiene e Saúde Pública, revelou o seguinte: 
Em 748 estudantes do sexo masculino, examinados em 1949, foram encontradas $4.3 \%$ de reações positivas para a sífilis. Em 1.164 reações sorológicas de universitários realizadas em 1950, foram observados $2,2 \%$ de resultados positivos.

XII - Um inquérito sorológico realizado em setembro de 1951 entre soldados da Fôrça Pública de São Paulo revelou o seguinte:

Entre 257 soldados do Batalhão de Guardas foi observada uma taxa de $8,71 \%$ de reações positivas; e $17,5 \%$ entre 165 soldados do Regimento de Cavalaria.

XIII - Segundo estudos realizados em presídios de várias partes do mundo, os presidiários costumam apresentar taxas de sífilis bastante elevadas.

Analisando as fichas de 1.121 prisioneiros da Penitenciária do Estado de São Paulo encontramos $32,0 \%$ de reações sorológicas positivas para a sífilis.

XIV - A capital de São Paulo, apesar de estar incluida entre as grandes cidades do mundo, apresenta um espetáculo degradante, com uma zona de meretrício como raramente se encontra em centros civilizados.

Um inquérito sorológico realizado entre 1.000 prostitutas da zona do meretrício do Bom Retiro, em 1948, apresentava a taxa de $83.6 \%$ de reações positivas para a sífilis.

Repetido o inquérito em 1951, foi observada uma taxa de $35,3 \%$ de positividade.

O uso frequente da penicilina pelas prostitutas foi considerado como sendo um dos principais fatôres pela diminuição da taxa de positividade da sífilis entre essas mulheres.

Foi recomendada, como medida de emergência em relação às meretrizes do Bom Retiro, uma intensa campanha sanitária entre essas mulheres, além do tratamento gratuito no Posto Anti-Venéreo do Departamento de Saúde, à rua Carmo Cintra. A medida ideal, no entanto, seria a repressão da prostituição em tôdas as suas formas.

XV - As taxas de incidência e prevalência da sífilis estão caindo. nas várias partes do mundo onde o seu estudo tem sido realizado. Alguns autores acham que é prematuro o otimismo dos sanitaristas em relação à possibilidade de uma fácil erradicação dessa moléstia no seio da população.

Na capital de São Paulo, segundo alguns estudos comparativos, observa-se diminuição da taxa de prevalência da sífilis em certos grupos sociais.

XVI - As taxas de positividade das reações sorológicas para diagnóstico da sífilis, encontradas em alguns grupos da população paulistana não são, de uma maneira geral, elevadas. Considerada a situação econômica e educacional do grupo operário examinado no presente trabalho, a taxa de $3,8 \%$, observada, é baixa. No entanto, índices mais elevados parecem existir em outras regiōes, como sugerem os dados encontrados entre imigrantes do norte e nordeste do país. 
XVII - O portador de sífilis e outras doenças venéreas, encarado sob o ponto de vista psicológico, apresenta um problema importante para o sanitarista. No entanto, o aspecto psicológico das doenças venéreas nunca é levado em conta nas campanhas contra tais doenças, o que constitui uma falha muito grande, segundo os venereologistas e psiquiatras modernos.

\section{SUMMARY AND CONCLUSIONS}

I - Syphilis, for various reasons, merits special distinction in the study of venereal diseases, and constitutes an important problem in Public Health.

It is necessary, for the establishment of a program for the control of syphilis in a region, to know the rates of incidence and prevalence. However, neither São Paulo, nor the rest of Brazil, presents accurate data on the frequency of syphilis in the population.

II - The mass serological survey is one of the best methods for studying the prevalence of the disease in a population, and also takes into consideration the various causes of errors.

, III - The problem of syphilis in industry is considered as being most important in relation to the number of work hours lost, and for the number of pensions and compensations that result.

In São Paulo, an industrial city, the study of syphilis among the workers is of indubitable importance.

IV - A study made during 1950-1951 in the paulista capital, revealed a rate of positive serological reactions of $3.81 \%$, in 20.892 workers examined.

$\mathrm{V}$ - The impression was confirmed that the positive rate increases in a more accentuated manner up to the age of 30 , remaining more or less stable up to 60 years, diminishing after this age.

VI - The masculine workers presented a higher rate of positive serological reactions $(4.39 \%)$ than the feminine sex $(2.78 \%)$.

VII - The white workers presented a lower rate of positivity $(3.25 \%)$ than was observed among mulattos $(8.81 \%)$, and negroes $(9.42 \%)$.

VIII - In the group of married workers, the percentage of positive reactions was higher $(4.89 \%)$ than the rate encountered among single $(2.79 \%)$.

Married men presented a higher rate $(4.80 \%)$ than single $(3.63 \%)$.

Married women workers presented a rate higher $(4.88 \%)$ than non-married $(1.83 \%)$.

IX - No significant difference was observed in the rate of positivity between married workers and widows and widowers.

$\mathrm{X}$ - It was noted that the rate of positive reactions was higher in Brazilian $(3.92 \%)$ than in non-Brazilian workers $(2.90 \%)$. 
XI - It seems a relationship exists beween educational and cultural factors and the rate of incidence and prevalence of syphilis. All authors agree that the percentage among students is low.

A study made from the records of students at the University of São Paulo matriculated in the Centro de Aprendizado da Faculdade de Higiene e Saúde Pública revealed:

In 778 male students examined in $1949,4.3 \%$ were found to have had syphilis at some time in the past.

In 1,164 serological tests made on students in 1950 a positive rate of $2 \%$ was found. It would be lower if we considered that cases in treatment with repeated tests were included.

XII - A serological survey made in September 1951, among soldiers of the Fôrça Pública presented the following results:

Of 257 soldiers of the Batallion of Guards, a rate of $8.17 \%$ positives was observed. Among 165 soldiers of a Cavalry Regiment, 17.5\%.

XIII - Studies made in prisons in various parts of the world show a high rate of syphilis among prisoners.

On analising the records of 1,121 prisioners of the Penitenciária do Estado de São Paulo, we encountered a positive rate of $32.9 \%$.

XIV - The capital of São Paulo presents a degrading spectacle, with a red light district which is rarely seen in other civilized cities.

A serological survey of 1,000 prostitutes of Bom Retiro, in 1948, showed a positive rate of $86.3 \%$.

This survey was repeated in 1951 , with the rate dropping to $35.3 \%$ positive tests among 465 prostitutes from the same district. The frequent use of penicillin by prostitutes for venereal diseases and other illnesses, is considered one of the principal factors in the recent lower rate of positive reactions for syphilis among these women.

$\mathrm{XV}$ - The incidence and prevalence rate has been followed in various parts of the world, and studies have been made. Some authors find that the optimism of the sanitary experts in relation to the possibility of easy erradication of this disease among populations, is premature.

In the capital of São Paulo, following comparative studies, a diminution of the rate of prevalence of syphilis in certain social groups has been observed.

XVI - The rates of positive serological reactions for the diagnosis of syphilis, encountered in some groups of the paulistana population are not, generally speaking, high. Considering the economic and educational level of the group of workers examined in this present survey, a rate of $3.8 \%$ is low. Higher rates, nevertheless, apparently exist in other regions, as suggested by data found among the immigrants from the north and northeastern part of the country.

XVII - A person afflicted with syphilis and/or other venereal diseases, presents from a psychological viewpoint, an important problem for public health workers. The psychological aspect is seldom taken into consideration in campaigns against venereal disease, a fact which is recognized as a greater failing of psychiatrists and modern venereologists. 


\section{BIBLIOGRAFIA}

1. Nelson, Nels A. and Crain, Gladys L.: Syphilis, Gonorrhea and Public Health. Macmillan Co., New York, 1938.

2. Bauer, Theodore J.: International VD Activities of the U.S. Public Health Service. J. Social Hyg., 36:35, 1950.

3. Rice, C. E.: Cost and Loss from Syphilitic Blindness in the U.S. J. Ven. Dis. Inform., 20:91, 1939.

4. Iskrant, A. P.: The Economic Cost of Paresis in the U.S. J. Ven. Dis. Inform., 26:175, 1945 .

5. Expert Committee on Venereal Diseases, Report of the first session, 12/16 January 1948, Official Records of the WHO, No. 8, January 1948.

6. Guthe, T., and Hume, J. C.: International Aspects of Venereal Disease Problem, J. Social Hyg., 34:51, 1948.

7. United Nations Secretary General Report, $\Lambda / 319,1947$.

8. U.S. 'Technical Projects to Ethiopia, 1944-45, Report.

9. U.S. War Dept. Tech. Bull. TB Med., 174, 1945.

10. U.S. War Dept. Tech. Bull. TB Med., 150, 1947.

11. Epidemiology of Diseases of Naval Importance in China. Bureau of Medicine and Surgery, Chapter XVIII, Nav. Med., 630, Washington, D.C.

12. Twenty-five Years (1918-1943) of Soviet Health Work, by Ministry of Health of S.S.R., State Publishing House of Medical Literature, 1944.

13. a) U.S. Statistic Bombing Survey; The Effetct of Bombing on Health and Medical Care in Germany. U.S. War Deprt., Washington, D.C., 1945. b) Relatório do Governador Militar, Office of M.G. for Germany. Public Health and Medical Affairs.

14. Lade, J. H.: UNRRA Medical Report on Poland, 1946, V.D. Chapter.

15. Sundhetstilstanden of Medicinal forholdane. Norges Officielle Statistikk, 1940-45.

16. Putkone, 'launo Dr. (Informações pessoais), Diretor do Serviço de Doenças Venéreas da Finlândia, 1950.

17. The Organization, Development and Activities of the Caribbean Medical Centre of Port Spain, Trinidad. Caribbean Commission, Washington, D.C., 1946.

18. Prevalencia y Incidencia de la Sifilis en Venezuela. Trabajo de la División de Venereologia con la colaboración de los Medicos Venereologos del Ministerio de Sanidad y Asistencia Social, Quinta Sesión, Caracas, 1945.

19. Smillie, W. G.: Preventive Medicine and Public Health. Macmillan Co., New York, 1949, pág. 289.

20. Venereal Disease Control in the U.S.A. Report of the WHO Syphilis Commission World Ilealth Organization, Technical Report Series, No. 15, 1950.

21. Vonderlehr, R. H. and Usilton, L. J.: Syphilis among men of draft age in the United States. J.A.M.A., 120:1369, 1942.

22. Duarte, F.: Os primeiros estudos de Medicina no Brasil. Actas Ciba, ${ }^{\circ}$ 6, 1939.

23. Rabelo, E: Existia sífilis no Brasil na época do descobrimento? An. Brasil. Dermat. Sif., ano I, pág. 3, 1925.

24. Suassuna, M.: Sífilis - Contribuição ao estudo de sua história. Med. cir. pharm., n 164, dez. 1949.

25. Martius, Carlos F. P. von: Natureza, Doencas, Medicina e Remédios dos índlios Brasileiros (1844). Trad. de Pirajá da Silva, Edit. Nacional, 1939.

26. Piso, G.: Da Medicina Brasileira - Iivro'II - Das Doenças Endêmicas, pág. 39, ano 1648. Trad. do Prof. Alexandre Correia. Cia. Editora Nacional, 1948. 
27. Villas Boas, J. A.; Gonçalves, B. e Silveira Filho, F. A. S. (citação de): Incidência da sífilis no Exército. Rev. med. mil, n³, julho/set. 1940, pág. 11-17.

28. Clark, O.: Alguns dados sôbre a frequência da sífilis no Brasil. Fol. méd., 21: 321, 1940.

29. Almeida, A. C.: Reações de Kahn e Hemótipos - Contribuição do I.B.F. na seleção da Fôrça Expedicionária Brasileira. Rev. Med. Mil., ano XXXIV, $\mathrm{n}^{\circ} 3$, 1945, pág. 399.

30. Pedrosa, E.: 16.000 reações de Kahn para a $1^{\text {a }}$ D.I.E. Arq. Biol. Fxérc., 5: 61, 1944.

31. Oliveira, W. de: Alguns dados e aspectos da sífilis em São Paulo; incidência da sífilis sôbre a população. Arch. Hỵg. S. Pub., 3:77, 1938.

32. Pupo, J. A.: A Sífilis em São Paulo. Gaz. Clin. S. Paulo, ano XX, n 3, março 1922, pág. 36.

33. Stokes, J. H.; Beerman, H. y Ingraham, R. N.: Sifilologia, vol. II, Salvat Editores S. A., 1949, pág. 1236.

34. Brines, (). A.: Laboratory Diagnosis of Syphilis. Michigan Academy of Science, Arts and Letters, Ann Harbor, Mich. University of Michigan Press, 21:561, 1936.

35. Turnbull, H. M.: Alterations in arterial structure and their relation to syphilis. Quart. J. Med., 8:201, 1914/15.

36. Pohlen, L.: Ueber die Haüfigkeit der Syphilis und syphilitischen Folgezustïnde nach dem klinischen und pathologischen Gefund. Dermat. Wchnschr., 105:1469, 1937.

37. Rosahn, P. D.: Autopsy Studies in Syphilis. Supplement No. 21 to The J. of Ven. Dis. Inform., Federal Security Agency, 1947.

38. Warthin, A. S.: The new pathology of syphilis. Am. J. Syph., 2:425, 1918. The role of syphilis in the etiology of angina pectoris, coronary arteriosclerosis and thrombosis, and of sudden cardiac death. Am. Heart J., 6:163, 1930.

39. Nickel, H.: Statistische Untersuchugen über die Ilaufigkeit der lues am Obductionsmaterial. Wchnschr., 15:121, 1936.

40. Freitas Filho, I. e Melo, I. C.: A sifilis e sua mortalidade em diversas capitais brasileiras. Fol. med., 21:327, 1940.

41. Mignone, C. e Bicudo, J. C. S.: Contribuição ao estudo estatístico das causas da mortalidade néo-natal. Rev. Ilospital Clin. S. Paulo, 3:381, $19 \mathrm{fs}$.

42. Borges, D. Rosa Borges: Estudos sôbre Sífilis. Iivraria Ateneu, 1941, Rio de Janeiro.

43. Oliveira, W.: Alguns dados e aspectos da sífilis en São Paulo. Arch. Hỵg. S. Pub., 2:219, 1936 .

44. Cerruti, H.: Estatística de 26 anos da reação de Wassermann praticada no Lab. Central da Sta. Casa de Misericórdia de S. Paulo. Rev. da Ass. Paul. de Med., 11: $65,1937$.

45. Bianco, A.: Andamento epidemiológico em São Paulo da infeccão luética observado através dos dados estatísticos do Hospital Humberto I. Anais da $1^{a}$ Conferência Nacional de Defesa contra a Sifilis, set. 1940, Rio de Janeiro.

46. Porto, C. E., Brito e Silva, M.: A micro-reação de Chediak no estabelecimento diagnóstieo da sífilis. Rev. da Ass. Paul. de Med., 25: fev., 1945.

47. Paula Souza, (i. H.: Dados inéditos do Instituto de Higiene.

48. Borges, D. R. (citação de): Estudo sôbre sífilis. Ateneu, 1941, Rio de Janeiro.

49. Mendes de Castro: Consideraçōes sôbre a sífilis do escolar. Rev. de Med. e Cir. de S. Paulo, 8:29, 1948.

50. Godoy, A.: Contribuição ao estudo da sífilis congênita precoce. Maternidade e Infância, $8: 251,1949$. 
51. Vieira Macedo, J.: O problema médico-social da sífilis. Arq. de Higiene e Saúde Pública, 13:71, 1948.

52. Matuk, A.: Observação sôbre as primeiras 600 fichas médicas de empregados domésticos de São Paulo. Arq. da Soc. de Med. Legal e Crim. de S. Paulo, 15:89, 1944.

53. Turner, T. B.: Studies on Syphilis in the Eastern Health District of Baltimore City. Principles concerned in measuring the frequency of the disease. A. J. Hyg., $37: 259,1943$.

54. Clark, E. G.: Studies on Syphilis in the Eastern Health District of Baltimore City. Am. J. of Syphilis, Gon. and Ven. Dis., 29:455, 1945.

55. Ferrão, E. P.: Contribuição ao estudo da incidência da sífilis no meio escolar do Rio de Janeiro. An. 1" Conf. Nac. de Defesa contra a Sífilis. Rio de Janeiro, 1940, vol. I, pág. 99.

56. Moroder, J.: Los nuevos tratamientos de la sifilis y su repercusión en la lucha antivenerea. Edit. Beta, Buenos Aires, 1950.

57. Touraine, M. A.: Les fausses réactions sérologiques de la syphilis. Ann. Dermat. Syph., n² 2, fev. 1947, pág. 64.

58. Stokes, J. H.; James, G. W.: The Problem of the "Biologic False" or Nonspecific positive serologic Test for Syphilis. Am. J. Syphilis, Gon. \& Ven Dis., $33: 114,1949$.

59. Faget \& Ross, S. H.: Evaluation of positive Kolmer and Kahn tests in leprosy. J. Ven. Dis. Inform., 25:133, 1944.

60. Almeida, J. O. e Souza Carvalho, R. P.: Estudos sôbre a sorologia da lepra. Rev. Bras. Lep., 20:30, 1952.

61. Kampmeier, H R.: Fundamentos de Sifilologia. Saivat Edit., Buenos Aires, 191\%, pág. 38.

62. Stokes, J. H.; Beerman, H.; Ingrahn, N. R.: Sifilologia, vol. II, pág. 1281. Salvat. Edit., 1949.

63. Parran, T.; Venderlehr, R. A.: Plain Words About Venereal Disease. Reynal \& Ilitchock, Inc., New York, 1941.

64. Osborne, E. D.; Traenkle, H. L.; Dolce, F. A.: Syphilis in Industry. N. York State J. of Med., 40: Sept., 1940.

65. Koch, R. A.; Merrill, H. M.: Serologic Survey Among Labor Unions in Northern California. J. Ven. Dis. Inform., 23: Sept., 1942.

66. Smillie, W. G.: Preventive Medicine and Public Health. Mcmillan Co., New York, 1949.

67. Rosa Borges, D.: Ś́filis no meio operário paulista. Rev. Paul. Med., 21:501, 1942 .

68. Kinsey, A. C.; Pomeroy, W. B.; Martin, C. E.: Sexual Behavior in the Human Male. W. B. Saunders Co., Philadelphia, 1948.

69. Vonderlehr, R. H. e Usilton, L. J.: Syphilis Among Men of Draft Age in the United States. J.A.M.A., 120:1369, 1942.

70. Bowdoin, C. D.; Henderson, C. A.; Warrent, T. D.: Social Economic Factors in Syphilis Prevalence, Savannah, Georgia. J. Ven. Dis. Inform., 30:131, 1949.

71. Warner, W. L.; Hill, M. C.; Bowdin, C. D.; Rion, J. W.; McCall, B.: Syphilis Prevalence and Community Structure. J. Ven. Dis. Inform., 32:157, 1951.

72. Usilton, L. J.; Ruhland, G. C.: Survey of Venereal Diseases in the District of Columbia. J. Ven. Dis. Inform., 21:244, 1940.

73. Jason, R. S.: Incidence of Syphilis in the American Negro. Am. J. Syph. and Neuro., 19:313, 1935.

74. Ieman, I. I.: A Study of Diseases in the Negro. South Med. J., 27:33, 1934

75. Dal Molin, R.: Trabalho inédito, 1951. 
76. Kinsey, A. C.; Pomeroy, W. B.; Martin, C. E.: Sexual Behavior in the Human Male. W. B. Saunders Co., Philadelphia, 1948.

77. Bowdoin, C. D.; Henderson, C. A.; Warrent, T. D.: Socio-economic Factors in Syphilis Prevalence, Savannah, Georgia. J. Ven. Dis. Inform., 30:131, 1949.

78. Prevalencia $y$ incidencia de la sifilis en Venezuela. Trabajo de la División de Venereologia con la colaboración de los Medicos Venereologos del Ministerio de Sanidad y Asistencia Social, Quinta Sesión, Caracas, 1945.

79. Smillie, W. G.: Preventive Medicine and Public Health. Macmillan Co., New York, 1949.

80. Tumbleson, R. S.; Ennes Jr., H. W.: A Study of Syphilis in American Colleges. j. Soc. Hygiene, N. York, April, 1939.

81. Kilpiö, O.; Putkonen, T.; Pätiälä, R.: Incidence of Seropositive Syphilis among University Students in Finland. Eripainos Aikakauskirjasta Duodecim, n 12, 1948.

82. Wenger, C.; Usilton, I. J.: Social and Economic Factors in a Study of 10,000 syphilis patients at the U.S. P.H.S. Clinic, Hot Springs, Ark. J. Ven. Dis. Inform., 15, May, 1934.

83. Trabalho não publicado, realizado no Instituto de Higiene.

84. Castro, Mendes de: Considerações sôbre a sífilis do escolar. Rev. Med. Cir. de S. Paulo, 8:29, 1948 .

85. Mammana, V. Z.; Hidal, M.: Contribuição para o estudo da prevalência da sífilis entre alguns grupos sociais de São Paulo (trabalho apresentado à Secção de Dermatologia e Sifiligrafia da Ass. Paul. de Medicina em 11 de setembro de 1951).

86. T'rabalho inédito. Informações pessoais do autor.

87. Barros, J. M.: Incidência das doenças venéreas entre os universitários de São Paulo. Rev. Med. Cir. de S. Paulo, 9:53, 1949.

88. Moore, J. E.: An Evaluation of Public Health Measures for the Control of Syphilis. Am. J. of Syphilis, Gon. and Ven. Dis., 35:101, 1951.

89. Hinrichsen, J.: Venereal Disease in Major Armies and Navies of the World. Am. J. Syph., Gon. and Ven. Dis., 28:736, 1944.

90. Siler, J. F.: The Prevention and Control of Venereal Diseases in the Army of the United States of America. Army M. I3ull, n 67, 1943.

91. Vonderlehr, R. A.: Syphilis Among Selectees and Volunters. Prevalence in first Million Examined under the Selective Service Act, 1940. J.A.M.A., 117:1350, 1941.

92. Putkonen, T.: Suomen Sotaväen sukupuolitautien tilasto v. 1919-1947, sen vertailu ja yhdistäminen viralliseen tilastoon, $\mathrm{n}^{\circ} \quad 4, \mathrm{XXII}$ Vuosikerta, 1948.

93. Villas Boas, J. A.; Gonçalves, B.; Silveira Filho, F. A. S.: Incidência da Sífilis no Exército. Rev. Med. Mil., n³, julho/set. de 1940, pág. 17 (citação de).

94. Villas Boas, J. A.; Gonçalves, B.; Silveira Filho, F. A. S.: Meios de reduzir o contágio venéreo no Exército. Rev. Med. Mil., n 1, março de 1941, pág. 77.

95. Bicudo, J. B. P.: Da necessidade da profilaxia venérea em nosso país. Rev. Med. Mil., ano XXXIV, jan./março de 1947, pág. 47.

96. Villas Boas, J. A.; Gonçalves, B.; Silveira Filho, F. A. S.: Incidência da Sífilis no Exército. Rev. Med. Mil., n 3, julho/set. de 1940, págs. 11-17.

97. Lima, E.: Incidência da Sífilis na Marinha durante um quinquênio. An. da $1^{\circ}$ Conf. Nac. de Defesa contra a Sífilis, Rio de Janeiro, 1940, vol. I, pág. 87.

98. Pedrosa, E.: 16.000 reações de Kahn para a $1^{a}$ D.I.E. Arq. Biol. Exérc., 5:61, 1944.

99. Almeida, A. Coelho de: Reações de Kahn e Hemótipos. Contribuição do I.B.E. na seleção da Fôrça Expedicionária Brasileira. Rev, de Med. Mil., 34:115, 1945. 
127. Fournier, J. A.: Prophylaxie publique de la syphilis. Bull. Acad. de Med., Paris, 25:XVII, 1887.

128. Bronner, V.: La lutte contre la prostituition en URSS. La societé pour les rélations culturelles entre l'URSS et l'Étranger (VOKS), Moscou, 1936.

129. Stokes, J. H.: Informe sobre la Prostitución en el Control de las enfermedades venéreas. Inform. sobre Enf. Ven., abril, 1943.

130. Lentino, J.: Problema da Syphilis em São Paulo - Tese de doutoramento à Faculdade de Medicina de São Paulo, 1930.

131. Clarke, C. W.: Chancres studied from the Public Health Point of View. Ann. Int. Med., 13, Dec. 1939.

132. The world situation with regard to prostitution. J. of Soc. Hygiene, 35:170, 1949.

133. Souza Araujo, H. C.: Resposta a uma "Crítica de um sistema de profilaxia venérea”, citado na tese de doutoramento à Faculdade de Medicina, de José de Moraes Leme, 1926, pág. 99.

134. Informações pessoais, obtidas no Departamento de Saúde de Guaiaquil, 1951.

135. U.S. War Dept. 'Tech. Bull. T'B. Med. 150, 1945.

136. Barros, J. M.; Mammana, V. Z.; Belda, W.: Inquérito sorológico para o diagnóstico da sífilis entre as prostitutas da zona do meretrício de São Paulo, 1951 (trabalho em andamento).

137. Gringoire, P.: Excelsior, México, 1937.

138. Kinsie, P. M.: Sex Crimes and the Prostitution Racket. J. Soc. Hygiene, 36:250, 1950

139. Laune, F. F.: Fighting Sin in Paradise. J. Soc. Hygiene, Feb., 1946.

140. Flexner, A.: La Prostitution en Europe. Paris, 1919.

141. Smiley, D. F.; Gould, A. C.: Personal and Community Hygiene. Memillan, New York, 1944 (citação de).

142. Bejarano, J.: Examen Crítico de la Reglamentación de la Prostitución. Inf. sobre Enf. Ven., octubre, 1945, México.

143. Frappa, J.: Enquête sur la Prostitution. Paris, 1937.

144. Baliña, P. L.: Organización de la lucha antivenérea. La Semana Médica, $n^{\circ} 51$, 1936.

145. Almeida, 'Teófilo de: Sífilis e Prostituição no Ric de Janeiro. Arq. Fund. Gaffrée-Guinle, 1929.

146. Morais, N. O.: Estado atual da prostituição no Rio de Janeiro. Folha Médica, julho de 1942.

147. Bejarano, J.: Examen Crítico de la Reglamentación de la Prostitución. Inf. sobre Enferm. Ven., México, octubre de 1945

148. Parran, T.: Why dan't we stamp out Syphilis? Survey Graphic and Readers' Digest, July, 1936.

149. Parran, T.: Are we stamping out Syphilis? J. of Social Hyg., 34, april, 1948.

150. Heeren, R. H.; Iskrant, A. P.; Hibbets, R. S.: The Control of Syphilis in Iowa. J. Ven. Dis. Inform., 31:79, 1950.

151. Aufranc, W. H.: Are venereal diseases disappearing? J. Social Hyg., 36:343, 1950 .

152. Stokes, J.: Practioner and antibiotic age of VD control. J. Ven. Dis. Inform., 31, Jan., 1950 .

153. Koch, R. A.: Penicillin is not enough. J. Social Hyg., 36:305, 1950.

154. Clark, E. G.: Is Venereal Disease no Longer a Problem? Mensagem lida pelo autor, quando Presidente da XII Sessão Anual da Associação Americana de Doenças Venéreas, Washington, abril de 1950. 
100. Faria, Ruy: A sífilis no meio militar. Rev. Paul. Med., 24, março de 1944.

101. Macedo, J. Vieira de: O problema médico-social da sífilis. Arq. Hig. e Saúde Pública, 13:71, 1948.

102. Macedo, J. Vieira de: 'Trabalho inédito, 1951.

103. Mammana, V. Z.; Hidal, M.: Contribuição para o estudo da prevalência da sífilis em alguns grrupos sociais de São Paulo. Trabalho apresentado à Secção de Dermatologia e Sifiligrafia da $\Lambda$ ss. Paul. de Medicina em 11 de setembro de 1951.

104. Bowdoin, C. D.; Henderson, C. A.; Warrent, T. D.: Socio-economic Factors in Syphilis Prevalence, Savannah, Georgia. J. Ven. Dis. Inform., 30:131, 1949.

105. Palmer, M.: Psychiatric Implications of Venereal Diseases; An American Survey. Brit. J. of Ven. Dis., Sept. 1949 (citação de).

106. Koch, R. A.: Sorologic Survey and Venereal I)isease Educational Program at the San Francisco County Jail. J. Ven. Dis. Inform., 26:71, 1945.

107. Stanley, L. I.: Syphilis Among State Prisioners. J.A.M.A., 92:1238, 1929.

108. Jones, W. R.: Syphilis in Washington. U'rol. \& Cutan. Rev., 40:508, 1936.

109. Heller, J. R. Jr.: A Survey of Blood and Spinal Fluid Findings in Prisioners, J. Ven. Dis. Inform., 17:65, 1936.

110. Hawk, F. H.: Syphilis Among Fecieral Prisioners, United States Penitenciary, Annex, Fort Leavenworth. Kans. J. Ven. Dis. Inform., 15:267, 1934.

111. Huntley, W. B.: Syphilis treated with fever therapy in penal institutions. Arch. Phys. 'Therapy, 22:227, 1941.

112. Arvidson, C. G.: Fxperiences with venereal disease in Minnesota penal institution. Journal-Lancet, $\mathbf{5 8 : 1 3 1 ,} 1938$.

113. Simons, S.: Summary of a Wassedmann and Kahn testing survey at the South Carolina Penitenciary. J. South Carolina M. A., 34:34, 1938.

114. Lorenz, W. F.: Syphilis in Wisconsin M. J., 36:188, 1937.

115. Freedman, L. Z.: Venereal Disease Among Naval Prisioner. U.S. Nav. M. Bull., 48:722, 1948.

116. Becrman, H. \& al.: Syphilis, a Review of the Recent Literature. Arch. of Int. Medicine, 85:305, 1950.

117. Luz, A. Cerqueira: A incidência da neuro-sífilis entre os detentos da Casa de Detenção do Rio de Janeiro. Arq. da Fund. Gaffrée-Guinle, 59, 1938.

118. Macedo, J. Vieira de: O problema médico-social da sífilis. Arq. Higiene e Saúde Púb., 13:71, 1948.

119. Silva, P'. da e 'Telles, J. C. da: Sífilis e criminalidade. Rev. penal \& penit., 1: 37, 1940 .

120. Neville-Rolfe, Sybil: Social Biology and Welfare. George Mllen \& Unwin Ltd., L.ondon, 1949 .

121. Vedder, Edward B.: Syphilis and Public Health. Philadelphia and New York, 1918.

122. Richmond, Winifred V.: Enciclopedia Sessuale. V. Bompiani, 1947.

123. Ieague of Nations Inquiry into Measure of Rehabilitation of Prostitutes (Part I) Prostitutes - Their Early Lives. Geneva, C. 218. M. 120. 1938. IV.

124. Kempe, l'ange: Prostitution. William Heinemann, pág. 142, London, 1936.

125. Safier, B.; Corrigan, H. G.; Fein, E. J.; Bradway, K. P.: A Psychiatric Approach to the Treatment of Promiscuity. Am. Soc. Hygiene Ass., Pub. $n^{\circ}$ A-741, N. York, 1949.

126. Hinrichsen, J.: Venereal Disease in the Major Armies and Navies of the World. An. J. Syphilis, Gon. and Ven. Dis., 28:736, 1944. 
155. Moore, J. E.: An Evaluation of Public Health Measures for the Control of Syphilis. Am. J. of Syph., Gon. and Ven. Dis., 135:101, 1951.

156. Gomes de Matos, A.; Rosa Borges, D.; Barreto, M. F.; Sarmento, F. de M.; Faria, J. de C.; Zacchi, S. M. A.; Verroni, O. B.; Gorga, P.; Paciornick, R. e Freitas, V. de: Subsídio para o Estudo Clínico e Estatistico da Sífilis Congênita Precoce. Ped. Prática.

157. Gomes de Matos, A.: Informações pessoais do autor sôbre um trabalho em andamento, outubro de 1951.

158. Moraes I.eme, J. H. de: O problema venéreo. 'Tese de dontoramento à Faculdade de Medicina de São Paulo, 1926.

159. Barros Barreto, J.; Costa, O. L. da; Teixeira, J. de M.: Arq. Hig., ano 13, dez. 1943. Ind. sanit. 1942, cap. Estados brasileiros.

160. Porto, C. E. e Brito e Silva, M.: A micro-reacão de Chediak no esclarecimento diagnóstico da sífilis. Rev. Ass. Paul. Med., 26, fev. 1940.

161. Kinser, A. C.; Pomeroy, W. B.; Martin, C. E.: Sexual Behavior in the Human Male. Saunders Co., Philadelphia, 1948.

162. Safier, B. \& al.: A Psychiatric Approach to the Treatment of Promiscuity. Am. Social Hyg. Assoc., Publ. n A-741, 1949.

163. P'almer, M.: Psychiatric implication of Venereal Diseases; An American Survey. Brit. J. of Ven. Dis., Sept., 1949.

164. Freud, S.: Ensayo sobre la vida sexual y la teoria de las neurosis. Aportaciones a la psicologia de la vida erotica. Trad. de Luís Lope\%-Ballesteros y de Torres, Bib. Nova, Madrid, 1948.

165. Brody, M. W.: Men who contract venereal disease. J. Ven. Dis. Inform., 29: 334, 1948.

166. Wittokower, E. D.: The Psychological Aspects of Venereal Disease. Brit. J. Ven. Dis., 24:59, 1948.

167. Iuehrs, E. L.: The Venereal Disease Patient as a Delinquent. J. Social Hyg., $35: 26,1949$. 